Water Availability and Use Science Program

\title{
Groundwater Availability of the Williston Basin, United States and Canada
}

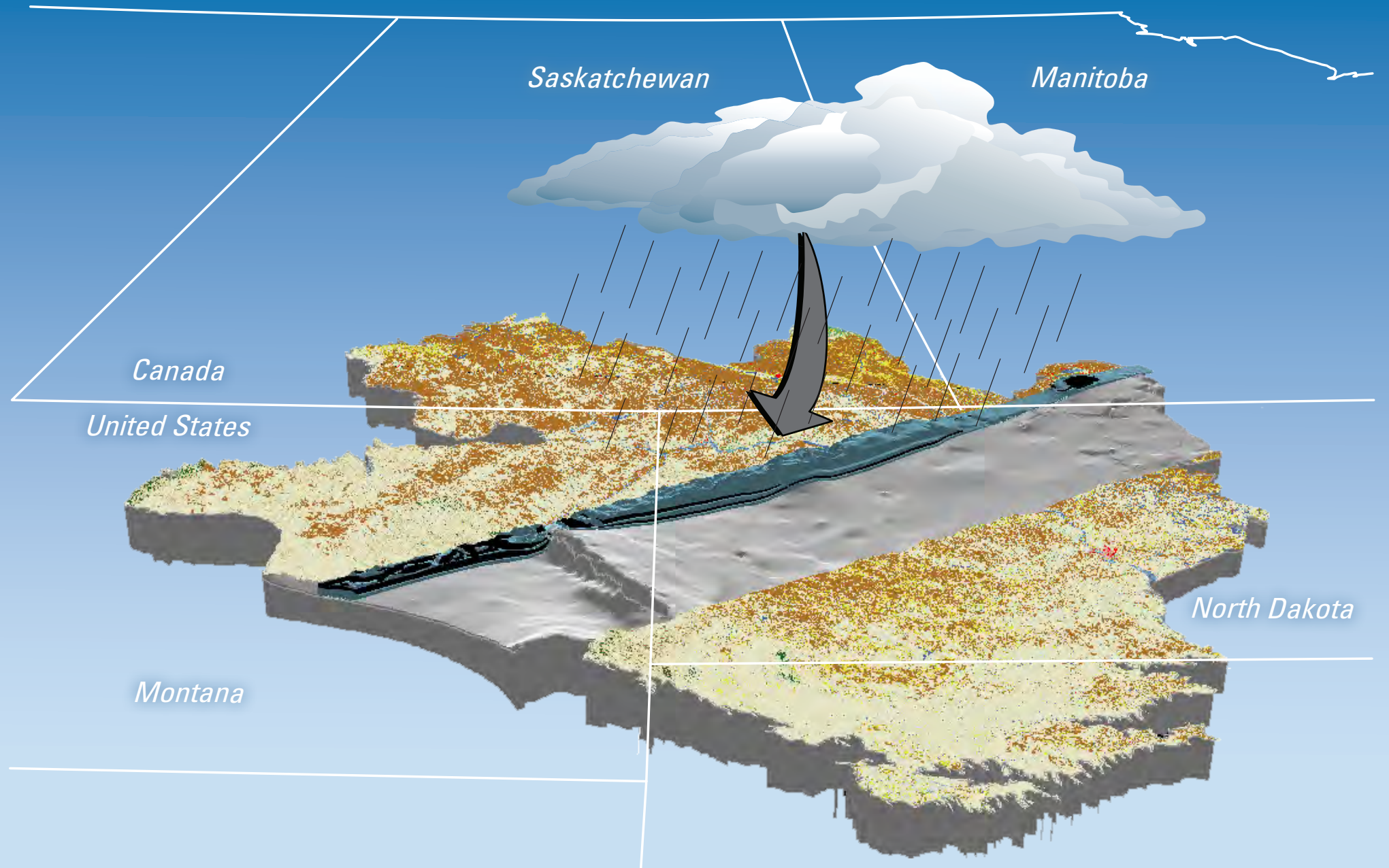

Professional Paper 1841 



\section{Groundwater Availability of the Williston Basin, United States and Canada}

By Andrew J. Long, Joanna N. Thamke, Kyle W. Davis, and Timothy T. Bartos

Water Availability and Use Science Program

Professional Paper 1841 


\section{U.S. Department of the Interior \\ RYAN K. ZINKE, Secretary}

\section{U.S. Geological Survey James F. Reilly II, Director}

\section{U.S. Geological Survey, Reston, Virginia: 2018}

For more information on the USGS — the Federal source for science about the Earth, its natural and living resources, natural hazards, and the environment-visit https://www.usgs.gov or call 1-888-ASK-USGS.

For an overview of USGS information products, including maps, imagery, and publications, visit https://store.usgs.gov.

Any use of trade, firm, or product names is for descriptive purposes only and does not imply endorsement by the U.S. Government.

Although this information product, for the most part, is in the public domain, it also may contain copyrighted materials as noted in the text. Permission to reproduce copyrighted items must be secured from the copyright owner.

Suggested citation:

Long, A.J., Thamke, J.N., Davis, K.W., and Bartos, T.T., 2018, Groundwater availability of the Williston Basin, United States and Canada: U.S. Geological Survey Professional Paper 1841, 42 p., https://doi.org/10.3133/pp1841.

\section{Library of Congress Cataloging-in-Publication Data}

Names: Long, Andrew J., author. | Geological Survey (U.S.), issuing body. Title: Groundwater availability of the Williston Basin, United States and Canada / Andrew J. Long [and three others].

Other titles: U.S. Geological Survey professional paper ; 1841. 1044-9612

Description: Reston, Virginia : U.S. Department of the Interior, U.S.

Geological Survey, 2018. | Series: Professional paper, ISSN 1044-9612 ;

1841 | Includes bibliographical references.

Identifiers: LCCN 2018040131 | ISBN 9781411342545 (paperback)

Subjects: LCSH: Groundwater--Williston Basin--Management. |

Aquifers--Williston Basin. | Water-supply--Williston Basin. | Basins

(Geology)--Great Plains. | Basins (Geology)--Manitoba. | Basins

(Geology)--Saskatchewan. | Williston Basin.

Classification: LCC TD403 .L66 2018 | DDC 628.1/140978--dc23 | SUDOC |

19.16:1841

LC record available at https://lccn.loc.gov/2018040131

ISSN 1044-9612 (print)

ISSN 2330-7102 (online)

ISBN 978-1-4113-4254-5 


\title{
Foreword
}

Although often overlooked, groundwater is increasingly important to all our lives. Groundwater is the Nation's primary reserve of freshwater. It provides half of the drinking water in the United States, is essential to food production, and facilitates business and industrial activities. Groundwater also is an important source of water for sustaining the ecosystem health of rivers, wetlands, and estuaries throughout the country.

Large-scale development of groundwater resources and their resulting declines in groundwater levels, as well as other effects of pumping, have led to concerns about the future availability of groundwater to meet our Nation's needs. The compounding effects of recent droughts emphasize the need for an updated status of the Nation's groundwater resources. Assessments of groundwater resources provide the science and information needed by the public and by policy makers to evaluate water availability and its effects on the water supply, and to manage and use the water resources responsibly. Adding to this already complex task of resource assessment is the analysis of potential future effects due to climate variability, which can exacerbate an already challenging situation.

The U.S. Geological Survey's Water Availability and Use Science Program is doing large-scale multidisciplinary regional groundwater availability studies (including the study described herein) of the uppermost principal aquifer systems of the Williston Basin. The regional studies are intended to inform citizens, communities, and natural resource managers about the status of the Nation's groundwater resources and about how changes in land use, water use, and climate have affected those resources. The studies also are intended to aid development of tools to forecast how these resources may change. The findings from these groundwater assessments of principal aquifer systems will be combined in an integrated national assessment. Results derived from these studies will help answer questions about the Nation's ability to meet current and future demands for groundwater.

\author{
Donald Cline \\ Associate Director for Water
}




\section{Acknowledgments}

This project was funded and supported by the U.S. Geological Survey Water Availability and Use Science Program, which includes the former Groundwater Resources Program. The authors thank the following U.S. Geological Survey personnel for their assistance and guidance throughout the project: Brian Clark, Geoff Delin (retired), Kevin Dennehy (retired), Daniel Feinstein, Mike Fienen, Seth Haines, Arlen Harbaugh, Randy Hunt, Chris Langevin, Howard Reeves, and Tom Reilly (emeritus). The authors gratefully acknowledge Matthew Bachmann for his assistance with the model scenarios, Katherine Chase for her assistance with research and development for precipitation text and illustrations, and DeAnn Dutton for her assistance with illustration support. The authors also thank Sue Kahle and Joshua Valder for providing excellent technical reviews of the report.

Sincere appreciation goes to Yves Michaud and Alfonso Rivera (Geological Survey of Canada), Graham Phipps (Manitoba Sustainable Development), Jon Reiten and Kevin Chandler (Montana Bureau of Mines and Geology), Attila Folnagy (Montana Department of Natural Resources and Conservation), Kimberly Fischer (North Dakota State Water Commission), and Kei Lo (Saskatchewan Water Security Agency), for their participation in monthly technical conference calls as part of the Williston Area Aquifers Modeling Consortium to discuss the groundwater resources of the Williston Basin. 


\section{Contents}

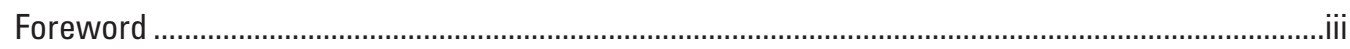

Acknowledgments ............................................................................................................

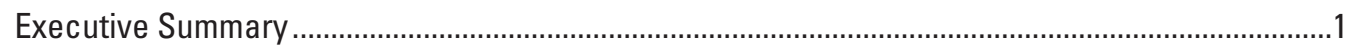

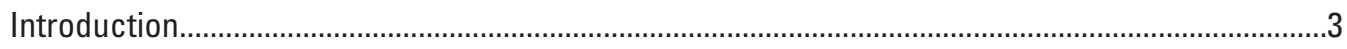

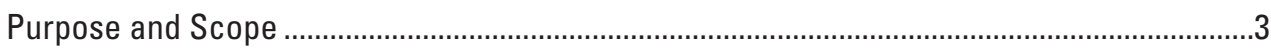

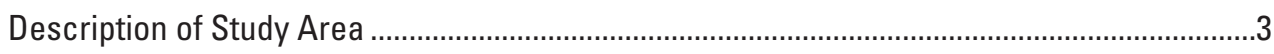

Energy Resources and Water Use.............................................................................

Physiography and Climate............................................................................................

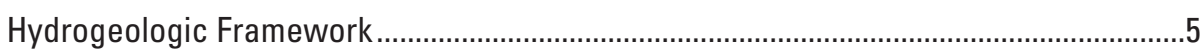

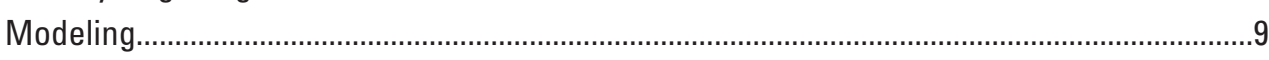

Conceptual Model of Groundwater Flow....................................................................

Summary of Numerical Modeling ...................................................................................11

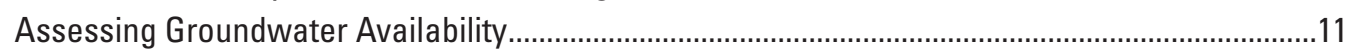

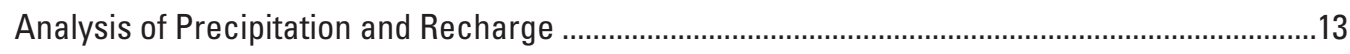

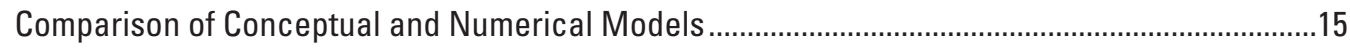

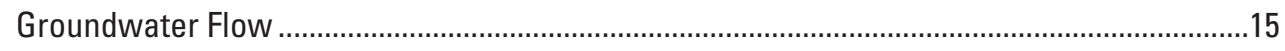

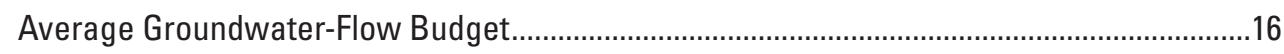

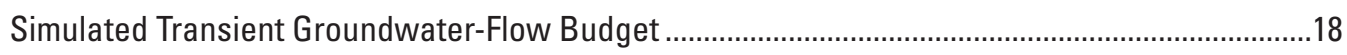

Simulated Groundwater Response to Flowing Artesian Wells ...................................................20

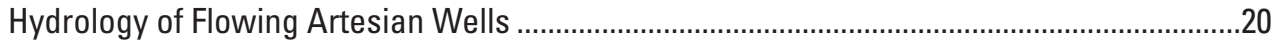

Scenario 1: Flowing Artesian Wells.......................................................................................20

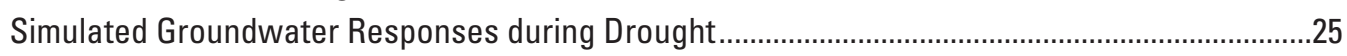

Scenario 2: Drought with Steady Groundwater Withdrawals..............................................2

Scenario 3: Drought with Increased Groundwater Withdrawals .........................................25

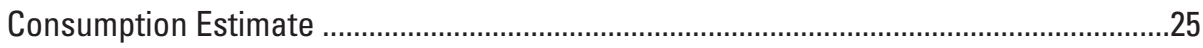

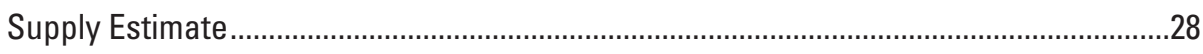

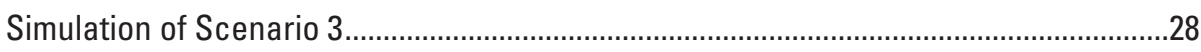

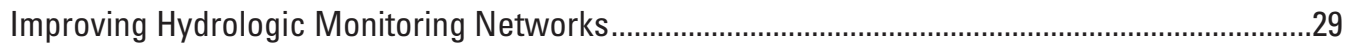

Numerical Groundwater-Flow Model Uses, Limitations, and Challenges .....................................38

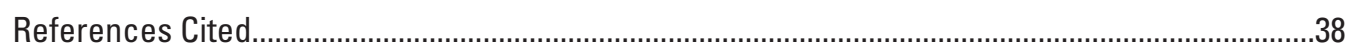




\section{Figures}

1. Map showing location of the Williston Basin and hydrogeologic unit layers, United States and Canada

2. Diagram showing lithostratigraphic and corresponding hydrogeologic units of the Williston Basin, United States and Canada.

3. Three-dimensional view of the top of the basal confining unit in the Williston and Powder River Basins, underlying the Upper Cretaceous aquifer system, United States and Canada..

4. Hydrogeologic cross section $A-A$ ' showing the glacial, lower Tertiary, and Upper Cretaceous aquifer systems in the Williston Basin, United States and Canada

5. Conceptual model of groundwater flow in the Williston Basin, United States and Canada

6. Graphs showing annual cumulative departure from the mean for precipitation and simulated precipitation recharge as a spatial average within the active model area, and precipitation for selected weather stations

7. Map showing locations of weather stations and long-term precipitation (1981-2011) data in the study area, Williston Basin, United States and Canada

8. Diagram and pie charts showing simulated groundwater-flow budget, Williston Basin, United States and Canada.

9. Graphs showing simulated groundwater-flow budget by stress period (predevelopment-2005) for the glacial aquifer system, lower Tertiary aquifer system, and Upper Cretaceous aquifer system for the control volume, Williston Basin, United States and Canada.

10. Graph showing groundwater withdrawals from wells, by aquifer system, Williston Basin, United States and Canada.

11. Map showing scenario 1 simulated hydraulic-head change from 1961 to 2005 for the Fox Hills aquifer, Williston Basin, United States and Canada

12. Map showing scenario 1 simulated hydraulic-head change from 1961 to 2035 for the Fox Hills aquifer, Williston Basin, United States and Canada

13. Graphs showing scenario 1 simulated and measured hydrographs of hydraulic head for four monitoring wells open to the Fox Hills aquifer and total flow from flowing artesian wells, Williston Basin, United States and Canada

14. Map showing scenario 2 simulated hydraulic-head change from 2005 to 2015 for the glacial aquifer system (model layer 2), Williston Basin, United States and Canada

15. Map showing scenario 2 simulated hydraulic-head change from 2005 to 2015 for the upper Fort Union aquifer, Williston Basin, United States and Canada

16. Map showing scenario 3 simulated drawdown of hydraulic head resulting from groundwater withdrawals for energy-resource production for 2015 in the glacial aquifer system (model layer 2), Williston Basin, United States and Canada.

17. Map showing scenario 3 simulated drawdown of hydraulic head resulting from groundwater withdrawals for energy-resource production for 2015 in the upper Fort Union aquifer (model layer 3), Williston Basin, United States and Canada..

18. Map showing scenario 3 simulated drawdown of hydraulic head resulting from groundwater withdrawals for energy-resource production for 2015 in the middle Fort Union hydrogeologic unit (model layer 4), Williston Basin, United States and Canada. 


\section{Figures-Continued}

19. Graph showing scenario 3 simulated change in the groundwater-flow budget from 2005 to 2015 for the active model area, Williston Basin, United States and Canada.

20. Map showing results of data-worth analysis for hydraulic-head forecasts at site H6, Williston Basin, United States and Canada 34

21. Map showing results of data-worth analysis for hydraulic-head forecasts at site H2, Williston Basin, United States and Canada

22. Map showing results of data-worth analysis for hydraulic-head forecasts at site H1, Williston Basin, United States and Canada

23. Map showing results of data-worth analysis for streamflow forecasts at site F3, Williston Basin, United States and Canada....

\section{Table}

1. Estimated and simulated average groundwater-flow budget for 1981-2005 within a control volume of the active model area.

\section{Conversion Factors}

U.S. customary units to International System of Units

\begin{tabular}{|c|c|c|}
\hline Multiply & By & To obtain \\
\hline \multicolumn{3}{|c|}{ Length } \\
\hline inch (in.) & 2.54 & centimeter $(\mathrm{cm})$ \\
\hline foot $(\mathrm{ft})$ & 0.3048 & meter $(\mathrm{m})$ \\
\hline mile (mi) & 1.609 & kilometer $(\mathrm{km})$ \\
\hline \multicolumn{3}{|c|}{ Area } \\
\hline square mile $\left(\mathrm{mi}^{2}\right)$ & 2.590 & square kilometer $\left(\mathrm{km}^{2}\right)$ \\
\hline \multicolumn{3}{|c|}{ Volume } \\
\hline gallon (gal) & 3.785 & liter $(\mathrm{L})$ \\
\hline cubic foot $\left(\mathrm{ft}^{3}\right)$ & 28.32 & cubic decimeter $\left(\mathrm{dm}^{3}\right)$ \\
\hline cubic foot $\left(\mathrm{ft}^{3}\right)$ & 0.02832 & cubic meter $\left(\mathrm{m}^{3}\right)$ \\
\hline acre-foot (acre-ft) & 1,233 & cubic meter $\left(\mathrm{m}^{3}\right)$ \\
\hline \multicolumn{3}{|c|}{ Flow rate } \\
\hline acre-foot per day (acre-ft/d) & 0.01427 & cubic meter per second $\left(\mathrm{m}^{3} / \mathrm{s}\right)$ \\
\hline acre-foot per year (acre-ft/yr) & 1,233 & cubic meter per year $\left(\mathrm{m}^{3} / \mathrm{yr}\right)$ \\
\hline foot per day (ft/d) & 0.3048 & meter per day $(\mathrm{m} / \mathrm{d})$ \\
\hline foot per year (ft/yr) & 0.3048 & meter per year (m/yr) \\
\hline cubic foot per second $\left(\mathrm{ft}^{3} / \mathrm{s}\right)$ & 0.02832 & cubic meter per second $\left(\mathrm{m}^{3} / \mathrm{s}\right)$ \\
\hline gallon per day (gal/d) & 0.003785 & cubic meter per day $\left(\mathrm{m}^{3} / \mathrm{d}\right)$ \\
\hline million gallons per day (Mgal/d) & 0.04381 & cubic meter per second $\left(\mathrm{m}^{3} / \mathrm{s}\right)$ \\
\hline inch per year (in/yr) & 25.4 & millimeter per year (mm/yr) \\
\hline
\end{tabular}




\section{Datums}

Vertical coordinate information is referenced to the North American Vertical Datum of 1988 (NAVD 88).

Horizontal coordinate information is refereced to the North American Datum of 1983 (NAD 83). Altitude, as used in this report, refers to distance above the vertical datum. 


\title{
Groundwater Availability of the Williston Basin, United States and Canada
}

\author{
By Andrew J. Long, Joanna N. Thamke, Kyle W. Davis, and Timothy T. Bartos
}

\section{Executive Summary}

The Williston Basin of the Northern Great Plains is a sedimentary basin - a geologic bowl-like structure filled with layered sedimentary rocks dating as far back as the Paleozoic age. The basin, which is nationally important for the production of energy resources, spans Montana, North Dakota, and South Dakota in the United States, and Manitoba and Saskatchewan in Canada. The three uppermost principal aquifer systems are the glacial, lower Tertiary, and Upper Cretaceous aquifer systems. As deep as 3,000 feet (ft) at the center of the basin, these are the most accessible aquifer systems in the basin and are the primary sources of potable groundwater in much of this area. The glacial aquifer system consists of Quaternary-age unconsolidated till, silt, clay, outwash sand and gravel, and occasional cobbles and boulders. The lower Tertiary and Upper Cretaceous aquifer systems consist primarily of sandstone, siltstone, mudstone, shale, and coal.

As energy demands have increased in the basin, horizontal drilling and hydraulic-fracturing have been used (especially since 2005) to develop previously inaccessible formations - namely, the Bakken and Three Forks Formations. The basin has yielded a large supply of domestic oil and natural gas since the $1950 \mathrm{~s}$, but the technologies required to extract those materials use large amounts of freshwater. The increasing freshwater demands of energy production in the Williston Basin, in addition to population growth, have led to a need for new tools to assess groundwater resources.

Average annual precipitation ranges from about 6 inches in the southwestern part of the Williston Basin to more than 30 inches in the eastern part, with much less change from north to south. The spatial distribution of groundwater recharge is consistent with that of precipitation. Average long-term precipitation recharge to groundwater (1985-2011) is 10 inches or less and results partly from snowmelt during spring (March-April). Groundwater recharge also results from streams losing flow as they infiltrate the ground and from reservoir water seeping into the ground. Groundwater loses flow to streams and reservoirs by exfiltration through the streambed material or reservoir-bottom sediment. Exfiltration to streams provides important base flow that sustains streams during dry seasons. Groundwater withdrawals are used for agriculture, public supply, industry, and domestic needs. Declining groundwater levels resulting from continuously flowing artesian wells have occurred in the Upper Cretaceous aquifer system.

The availability of groundwater for human and ecological benefit is dependent on accessibility, volume, and the rate of replenishment, which are related to other interconnected and uncertain factors. These factors include climate variability, human use of groundwater and surface water, aquifer characteristics, continual changes in groundwater storage, and changes in the ease of extracting groundwater. Analyses in this report made use of an existing numerical groundwaterflow model that recently was described and documented for the Williston Basin. This model was calibrated to temporally varying conditions for 1961-2005 and was designed to forecast the outcomes of different hydrologic scenarios, examples of which are presented in this report.

A groundwater-flow budget that quantifies all inflows and outflows for the overall groundwater system is a valuable starting point for assessment of groundwater availability. Comparison of estimated and simulated groundwater-flow budgets indicates noteworthy similarities and differences. Differences resulting primarily from limitations inherent to estimating and simulating regional-scale groundwater flow help provide ranges of uncertainty in each flow component. The long-term averages for estimated and simulated precipitation recharge for the Williston Basin were 26 and 60 percent, respectively, of total groundwater recharge. Estimated and simulated stream infiltration to groundwater were 72 and 29 percent, respectively, of all groundwater recharge. Estimated and simulated stream exfiltration from groundwater into streams were 97 and 90 percent, respectively, of all groundwater discharge.

The lower Tertiary aquifer system has the largest overall groundwater-flow budget and the greatest variability of the three aquifer systems, whereas the Upper Cretaceous aquifer system has the smallest groundwater-flow budget and least variability. The Upper Cretaceous aquifer system has, on average, a groundwater-flow budget that is less than one-third as large as each of the other two aquifer systems but accounts for about 70 percent of the total well withdrawals; this largely is because flowing artesian wells discharging from the Upper Cretaceous aquifer system account for about 50 percent of all well withdrawals. 
The numerical groundwater-flow model of the Williston Basin was used to simulate three scenarios. Scenario 1 focused on flowing artesian wells, which were simulated as headdependent boundary cells; that is, the rate of well discharge is influenced by hydraulic head surrounding the well. The model was used to simulate 1960-2035 hydraulic-head changes that would result if none of the flowing artesian wells were capped or plugged during this period and other conditions remained constant. A conservative steady groundwater pumping rate was assumed for 2006-35, which was the period projected by the model because the model was calibrated for 1960-2005. Most of the simulated decline occurred during 1960-2005 for the area surrounding the flowing artesian wells; this drawdown area continued to expand through 2035 , with simulated hydraulic-head declines of as much as $170 \mathrm{ft}$.

The total rate of outflow for flowing artesian wells increased from 1960 to 1980 to a high of about 61 cubic feet per second $\left(\mathrm{ft}^{3} / \mathrm{s}\right)$, as the number of wells increased, and then varied between about 57 and $61 \mathrm{ft}^{3} / \mathrm{s}$ until 2003. After 2003, when few additional wells were installed, the simulated outflow decreased to about $54 \mathrm{ft}^{3} / \mathrm{s}$ in 2035 ; this decrease in outflow was steepest for the 2006 stress period and gradually flattened through the remainder of the simulation, which is consistent with a flattening of the simulated hydraulic-head declines, particularly after 2010 . This simulation indicates that the installation of flowing artesian wells initiated the hydraulic-head declines, which then resulted in decreases in outflow rates because of decreasing hydraulic pressure within the wells, and that outflows were moving toward an equilibrium state with hydraulic head. A second reason for the flattening of the simulated hydraulic-head decline was that many of the wells ceased to flow. Of the 300 flowing artesian wells simulated, 75 wells ceased to flow by the end of 2035 because hydraulic head had declined below the landsurface. Although scenario 1 indicates decreasing severity of hydraulic-head decline for the future, different scenarios also should be considered, such as continued increase in groundwater pumping rates and drier climatic conditions, including long-term drought.

Scenarios 2 and 3 offer two additional examples, but many other possibilities could be simulated with the groundwater-flow model. Scenario 2 simulated 10-year drought for 2006-15, with no increases in groundwater pumping after 2005. For most of the western part of the active model area, simulated groundwater declines were small, in the range of $0-1 \mathrm{ft}$, for the glacial and lower Tertiary aquifer systems. Much of the eastern areas show declines in the range of $1-5 \mathrm{ft}$, with more than $5 \mathrm{ft}$ of decline in many areas and more than $200 \mathrm{ft}$ in some parts of the glacial aquifer system. These results show the change that followed a period of low to moderate precipitation-recharge rates; a drought simulation following higher recharge rates would result in much larger groundwater declines than those resulting from scenario 2 . Some of the central and western areas show simulated groundwater increases, primarily in the range of $0-1 \mathrm{ft}$, which is a result of spatio-temporal variability of precipitation.

Climatically wet eastern areas are more susceptible to groundwater declines during drought than are the dry western areas, and groundwater increases might occur in some western areas locally during drought because of spatio-temporal variability of precipitation.

Scenario 3 was identical to scenario 2, except that it also applied the increased groundwater withdrawals necessary to fill the needs of energy-resource production (ERP) for 2006-15. The freshwater used for ERP was estimated by two separate methods. The first method focused strictly on the estimated total freshwater needs for ERP in the Williston Basin within the United States. The second method focused on groundwater-withdrawal data obtained from water-use permits. Results of the two methods were consistent, which reduced uncertainty of these estimates. A combination of groundwater and surface water was used to supply the needs of ERP; however, if an extended drought occurred during this period, low streamflows and emptying of ephemeral lakes and ponds might have caused less surface-water availability. Therefore, the purpose of this scenario was to estimate the effects on the groundwater supply if ERP water demands were totally supplied by groundwater during a drought.

For scenario 3, the simulated drawdown was less than $25 \mathrm{ft}$. Most of the pumping wells added were in the glacial and Fort Union aquifer systems, and areas of drawdown coincide with these well locations. Much of the simulated drawdown occurred within areas of the Little Muddy aquifer, which is a sand and gravel aquifer within the glacial aquifer system; numerous permitted wells added in scenario 3 withdraw water from this aquifer. The total area affected by pumping wells added in scenario 3 is small but affects large parts of local areas. The simulated change from 2005 to 2015 included a decrease in precipitation recharge of 64 percent, which was the primary forcing that caused a 28 percent decrease in the net outflow to surface water. Simulated pumping-well outflow increased by 34 percent, and flowing-well outflow decreased by 4 percent.

Numerical groundwater-flow models are used to inform water-management decisions, and a useful model application is to design a monitoring network that would provide data that best improves the predictive ability of a model through reduction of uncertainty. Uncertainty of simulated hydrologic forecasts, or "predictive uncertainty," can be reduced by providing additional data for model calibration. If the new data were to come from a new observation well, for example, the degree of reduced uncertainty would depend on the specific location of the new well. One way to determine the best locations for new observation wells is to apply a method referred to as a "data-worth analysis." Examples of how the numerical model can be used to assist in selecting locations for new observation wells were applied and described. 


\section{Introduction}

\section{Purpose and Scope}

The increasing freshwater demands of energy production in the Williston Basin necessitate new tools to assess groundwater resources. Because of the importance of groundwater in this energy-rich area, the U.S. Geological Survey (USGS) began a study in 2011 to assess and provide better tools that can be used to manage groundwater availability in the Williston Basin. The purpose of this report is to describe the results of that study. Specifically, this report describes (1) the current groundwater availability of the three uppermost principal aquifer systems - the glacial, lower Tertiary, and the Upper Cretaceous - in the Williston Basin, (2) how these resources have changed over time, and (3) tools to assess system response to anthropogenic stresses and climate variability. The scope of this report is focused on the Williston Basin and summarizes previous publications that resulted from this study describing a hydrogeologic framework, a conceptual model and groundwater-flow budget, and a numerical model of groundwater flow (Long and others, 2014; Thamke and others, 2014; Davis and Long, 2018a). This report presents hydrologic forecasts simulated with this numerical model to assess the potential for drought, pumped groundwater, and free-flowing artesian wells to affect future groundwater availability. An example of the use of this model to help determine high-value locations to establish new hydrologic-monitoring stations also is presented. The study described in this report has benefitted from numerous studies and publications dating from the 1960s until present, most of which were summarized by Long and others (2014), Thamke and others (2014), and Davis and Long (2018a). A brief summary of the key findings from this report is in Thamke and others (2018).

This report is one in a series of reports summarizing the findings of USGS assessments of groundwater availability of principal aquifers throughout the United States. These include assessments of the Middle Rio Grande Basin, New Mexico (Bartolino and Cole, 2002); the Southwest Alluvial Basins (Tillman and others, 2008); the Central Valley Aquifer, California (Faunt, 2009); the Atlantic Coastal Plain of North and South Carolina (Campbell and Coes, 2010); the Great Basin Carbonate and Alluvial Aquifer System (Heilweil and Brooks, 2010); the U.S. Great Lakes Basin (Reeves, 2010); the Denver Basin Aquifer System, Colorado (Paschke, 2011); the Mississippi Embayment (Clark and others, 2011); the Columbia Plateau Regional Aquifer System (Vaccaro and others, 2015); the North Atlantic Coastal Plain Aquifer System (Masterson and others, 2016); and the Glacial Aquifer System of the United States (Reeves and others, 2017). A map of principal aquifers of the United States is accessible from U.S. Geological Survey (2018).

\section{Description of Study Area}

The Williston Basin is a sedimentary basin-a geologic bowl-like structure filled with layered sedimentary rocks. The basin is as deep as 10,000 feet (ft) and consists of Paleozoic, Mesozoic, and Cenozoic-age formations that overlie Precambrian-age rocks (Sandberg, 1962; Downey and Dinwiddie, 1988; Dolton and others, 1990). The basin is nationally important for the production of energy resources, spanning Montana, North Dakota, and South Dakota in the United States, and Manitoba and Saskatchewan in Canada (Thamke and others, 2014). The three uppermost principal aquifer systems in the basin are the glacial, lower Tertiary, and Upper Cretaceous. They are the most accessible aquifer systems in the basin and are the primary sources of potable groundwater in much of the area (fig. 1). The glacial aquifer system, present in the northern and eastern parts of the Williston Basin, is composed primarily of glacial drift. The lower Tertiary and Upper Cretaceous aquifer systems, throughout most of the basin, are composed of sedimentary rocks including shale, silt, sandstone, and coal. In the Williston Basin, these three aquifer systems are as deep as $2,850 \mathrm{ft}$ below land surface and overlie $800-2,000 \mathrm{ft}$ of relatively impermeable Upper Cretaceous marine shale that serves as a basal confining unit that impedes groundwater flow (Anna, 1986; Downey, 1986; Downey and Dinwiddie, 1988; Thamke and others, 2014). This report provides a broad-scale assessment of the complex topic of groundwater availability in the Williston Basin and describes tools that can be applied to help manage this resource.

\section{Energy Resources and Water Use}

The lower Tertiary and Upper Cretaceous aquifer systems extend into the Powder River Basin of Montana and Wyoming (fig. 1) and are part of the Northern Great Plains aquifer system (Whitehead, 1996). This larger aquifer system consists of all bedrock aquifers in North and South Dakota, eastern Montana, and northeastern Wyoming. Whitehead (1996) did not describe a Canadian extent of this aquifer system. In the United States, the Northern Great Plains aquifer system provides 101 million gallons per day $(\mathrm{Mgal} / \mathrm{d})$ of water to irrigation (66.6 Mgal/d), public supply (33 Mgal/d), and selfsupplied industrial use (1.62 Mgal/d) (Maupin and Barber, 2005). Most of this water is obtained from the lower Tertiary and Upper Cretaceous aquifer systems (Wesolowski, 1991). 


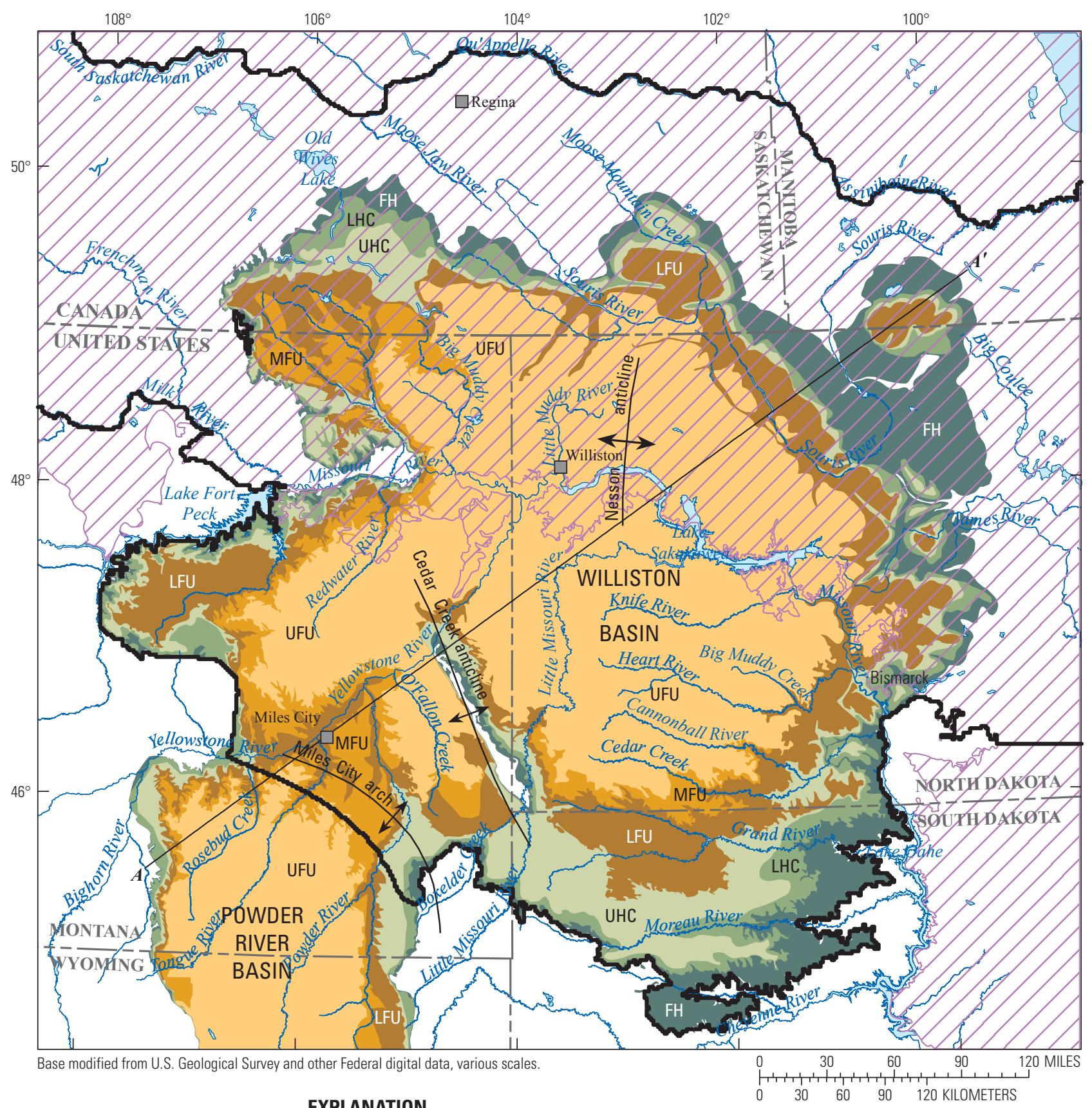

EXPLANATION

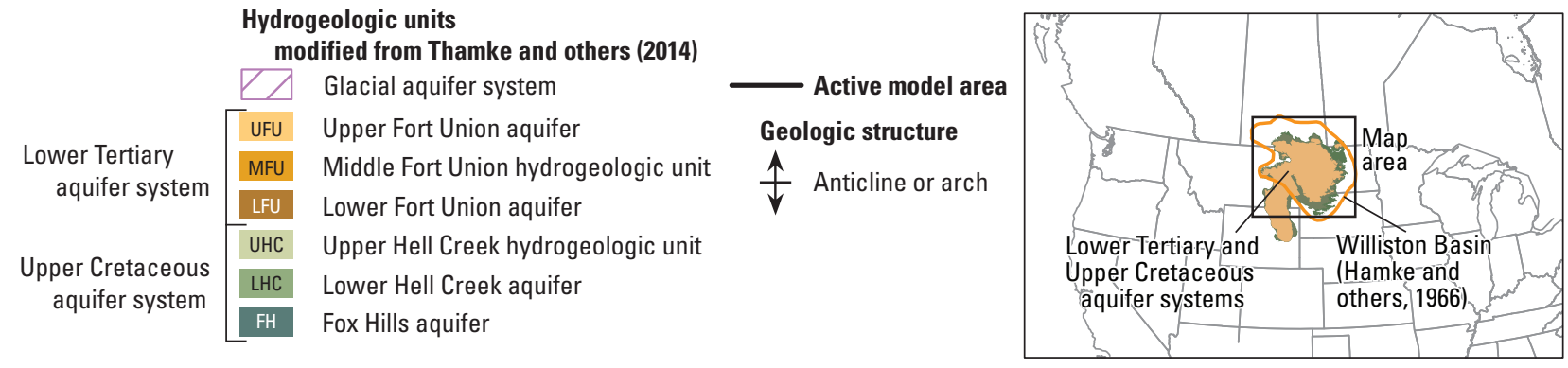

Figure 1. Location of the Williston Basin and hydrogeologic unit layers, United States and Canada. Cross section $A-A^{\prime}$ is shown in figure 4. Hydrogeologic units and geologic structures modified from Thamke and others (2014). 
Since 2005, as energy demands have increased, horizontal drilling and hydraulic-fracturing methods have been used to develop previously inaccessible formations in the Williston Basin - namely, the Bakken and Three Forks Formations (Gaswirth and others, 2013; U.S. Energy Information Administration, 2013). The Williston Basin has yielded a large supply of domestic oil and natural gas since the 1950s, but the technologies required to extract those materials use large amounts of freshwater, with the largest increases occurring since 2005 (Schuh, 2010; Anna and others, 2011; Haines and others, 2017; Barnhart and others, 2018). Water use for hydraulic-fracturing per oil well increased by about six times from 2005 to 2014 , totaling $24.5 \times 10^{9}$ gallons for about 10,140 wells (Scanlon and others, 2016). The increased demand for freshwater resulted in an increase of water pipelines by hundreds of miles and water-permit transfers from irrigation to oil production (Scanlon and others, 2016). Geologic units of early Tertiary and Late Cretaceous age contain most of the nation's reserves of coal, in the form of lignite and coalbed natural gas (Bluemle, 1998). Strip mining of coal consists of the removal of large volumes of host rock, thereby affecting aquifers, and coal bed natural gas extraction requires the removal of large volumes of groundwater from coal beds to release stored gases (Thamke and others, 2014). Continued development in the region, including alternative energy, industry, irrigation, and growing demands for domestic and municipal water in the Northern Great Plains, depends on the quantity and quality of groundwater available from these shallow and accessible aquifers.

\section{Physiography and Climate}

The study area includes the Williston Basin (fig. 1), the extent of which is not precisely defined but has been estimated by Hamke and others (1966), Pitman and others (2001), and Pollastro and others (2013). Topography in the study area is characterized by relatively low relief, except near large river channels, with a gently rolling land surface underlain by glacial drift and sedimentary rocks composed primarily of sandstone, coal, and shale. Large river systems such as the Missouri and Yellowstone Rivers erode the relatively soft sedimentary rocks and create several hundred feet of local topographic relief.

Surface-water resources in the Williston Basin include rivers, streams, lakes, and wetland ponds. In this area, the Missouri River flows toward the east and southeast, with the Yellowstone and Little Missouri Rivers entering from the south (fig. 1). The study area includes three large surfacewater reservoirs: Fort Peck Lake, Lake Sakakawea, and Lake Oahe, all located along the Missouri River (fig. 1). Several other tributaries in the southeastern part of the Williston Basin flow easterly and enter the Missouri River from the west. Numerous natural lakes and wetland ponds are scattered across the landscape in glacial deposits north of the Missouri River. Much of this area is characterized by a non-integrated drainage pattern, where few streams cross. Surface water is heavily appropriated in most of the study area (Schuh, 2010), and this water supply is not always dependable in upper ephemeral stream reaches.

The climate is semiarid, with monthly precipitation exceeding monthly potential evapotranspiration by less than 5 inches per year (in/yr) (Reilly and others, 2008). Within the study area, precipitation ranges from $6 \mathrm{in} / \mathrm{yr}$ in the southwestern part to more than $30 \mathrm{in} / \mathrm{yr}$ in the eastern part (Thornton and others, 1997, 2012; Long and others, 2014). Pasture and hayland covers 70 percent of the study area (Multi-Resolution Land Characteristics Consortium, 2011). Except for a few towns, population density generally is less than 10 people per square mile (Statistics Canada, 2001; U.S. Census Bureau, 2001).

\section{Hydrogeologic Framework}

Available groundwater resources used in the Williston Basin in the United States and Canada primarily are in three uppermost principal aquifer systems composed of Late Cretaceous, Tertiary, and Quaternary-age lithostratigraphic units (fig. 2). Thamke and others (2014) constructed a three-dimensional hydrogeologic framework that defined and described these three aquifer systems in the Williston Basin for the United States and Canada, with emphasis on the lower Tertiary and Upper Cretaceous bedrock aquifer systems. Davis and Long (2018a) further developed the hydrogeologic framework for the glacial aquifer system by spatially defining five glacial-material zones and extending this analysis to the edges of the active model area (fig. 1). This section summarizes the hydrogeologic framework described by Thamke and others (2014) and Davis and Long (2018a), which include greater detail of the lithostratigraphic and hydrogeologic units.

From shallowest (youngest) to deepest (oldest), the three principal aquifer systems are the glacial, lower Tertiary, and Upper Cretaceous aquifer systems, with the latter two contained within bedrock (fig. 2). These three principal aquifer systems are hydraulically separated from deeper aquifers by a basal confining unit composed primarily of $800-3,000 \mathrm{ft}$ of low-permeability marine shale of Upper Cretaceous age; the altitude of the top is shown in figure 3. The bowl-shaped structure and layered geology of the Williston Basin results in bedrock hydrogeologic units that are exposed to the land surface or are in contact with the overlying glacial aquifer system near the outer parts of the basin (figs. 1, 4). The glacial aquifer system overlies parts of the lower Tertiary and Upper Cretaceous aquifer systems in the northern part of the Williston Basin (fig. 1). 

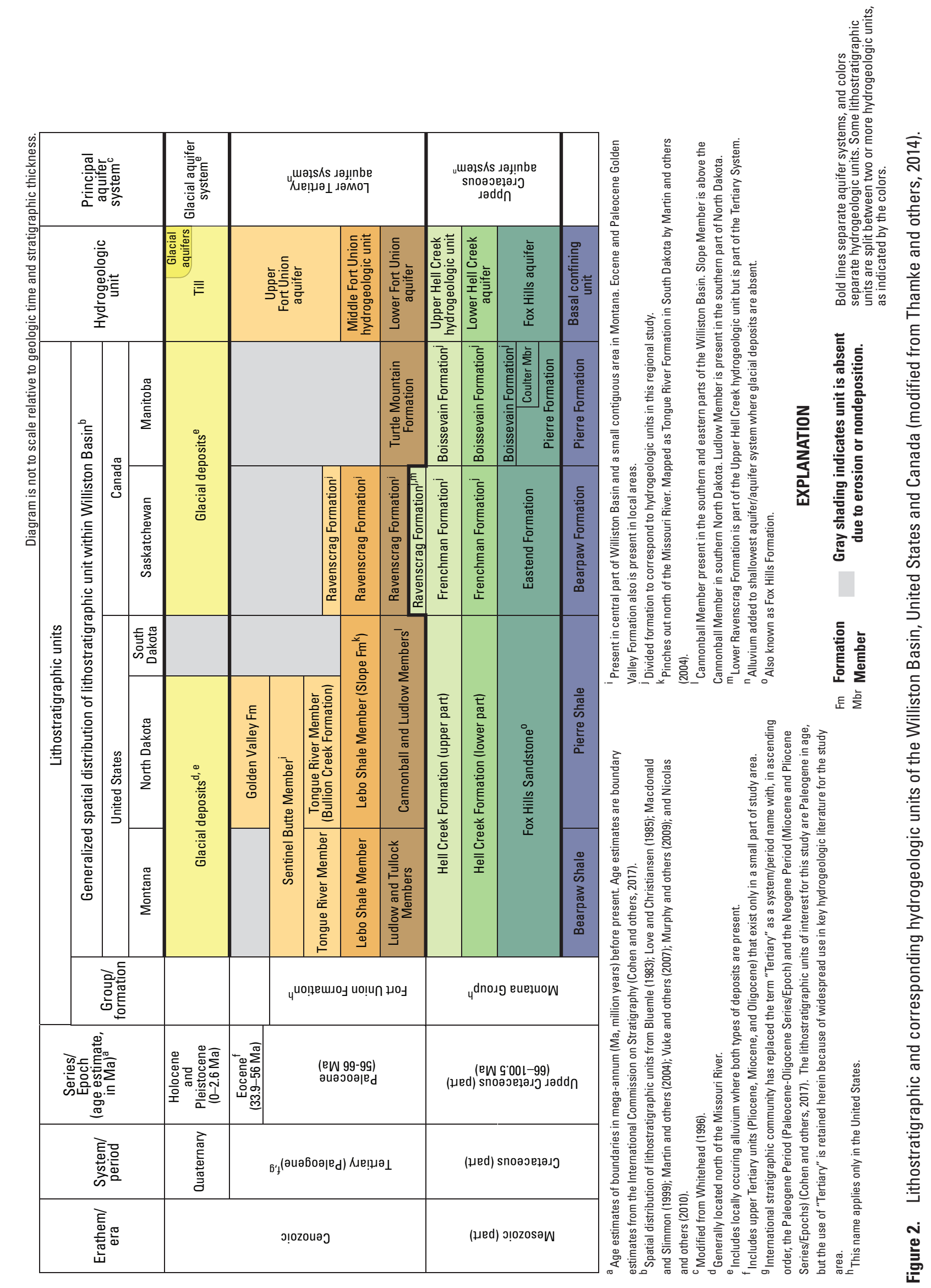


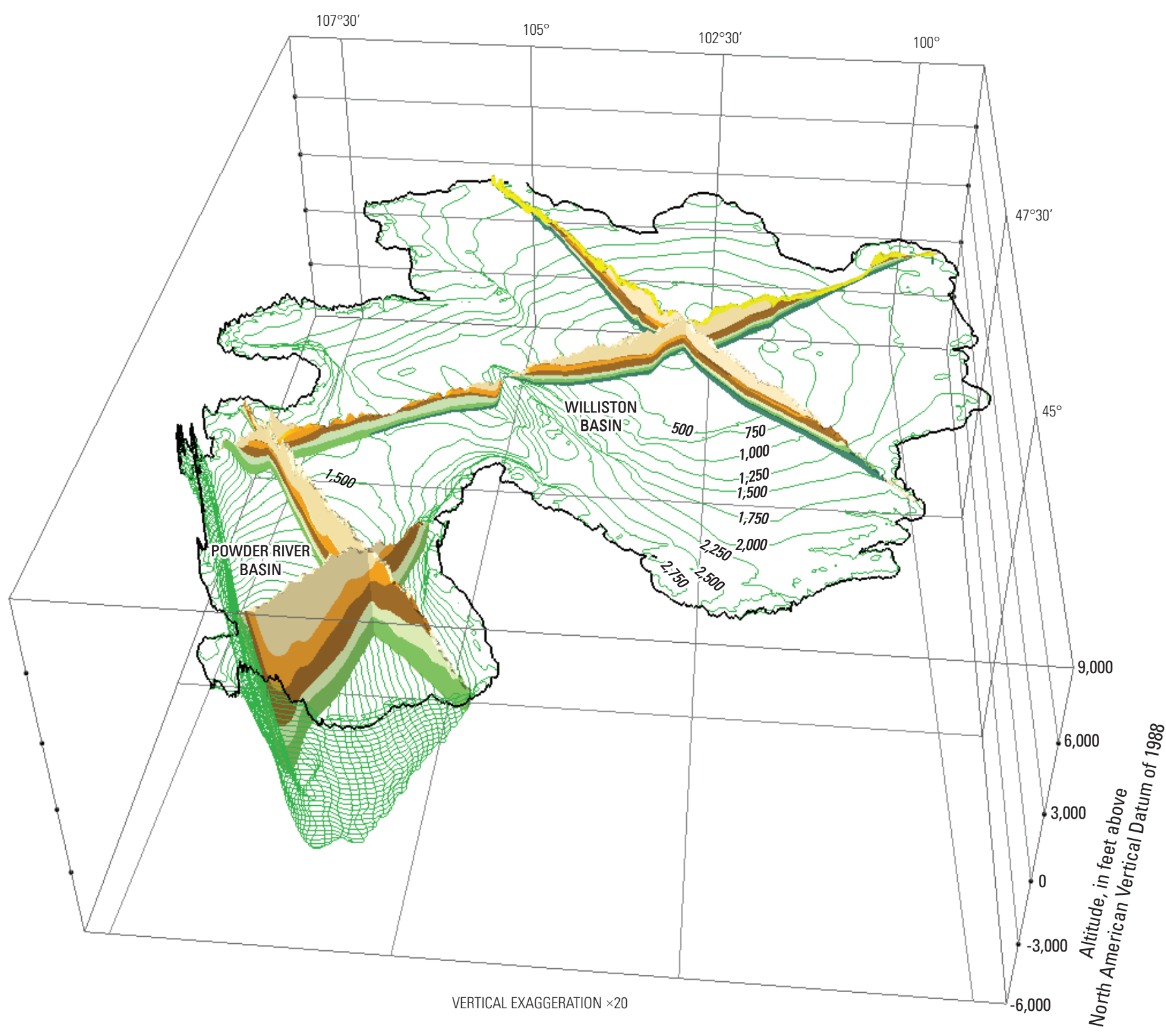

EXPLANATION

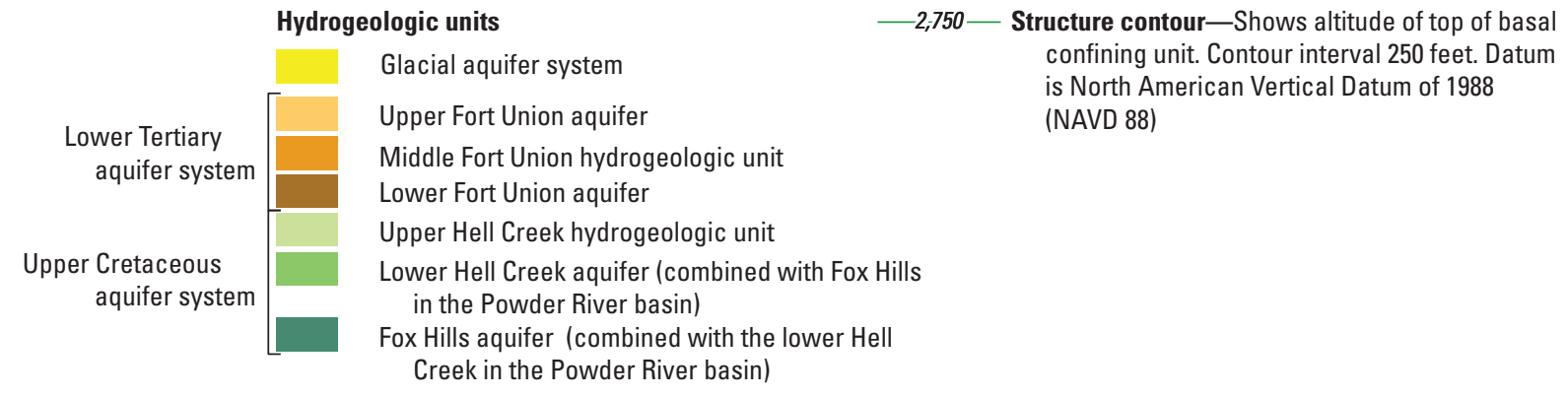

Figure 3. Three-dimensional view of the top of the basal confining unit in the Williston and Powder River Basins, underlying the Upper Cretaceous aquifer system, United States and Canada. Selected hydrogeologic units are shown, with selected hydrogeologic cross sections (from Thamke and others, 2014). 


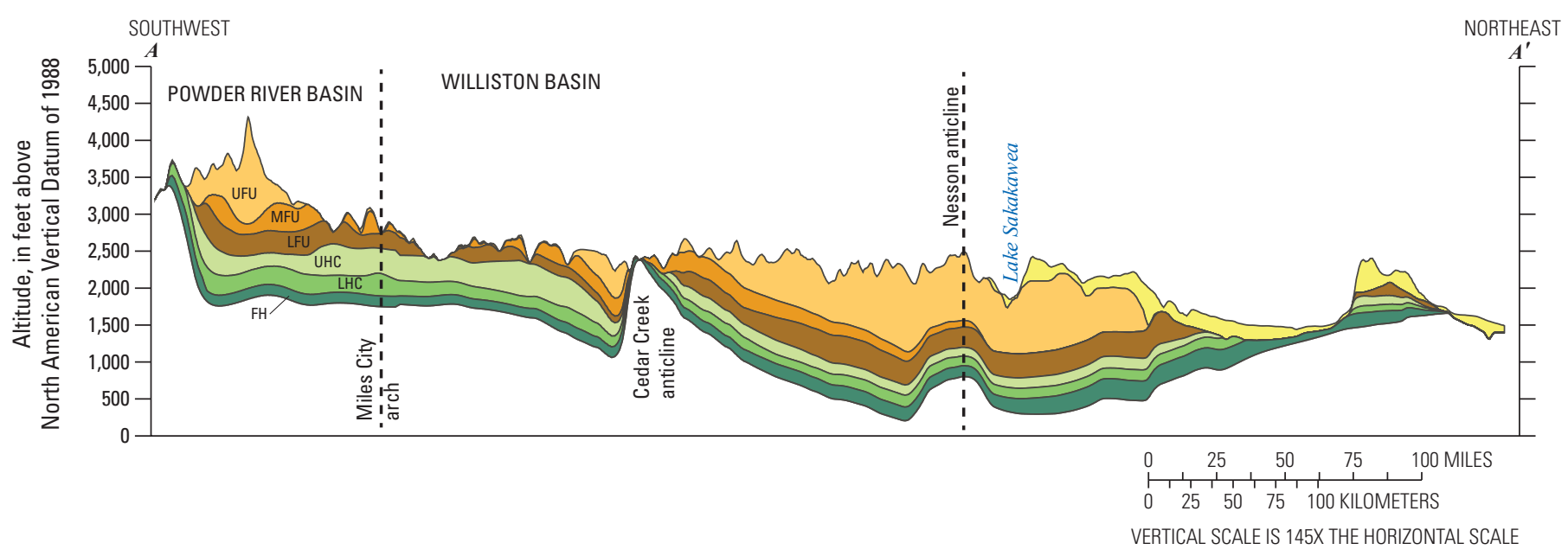

EXPLANATION

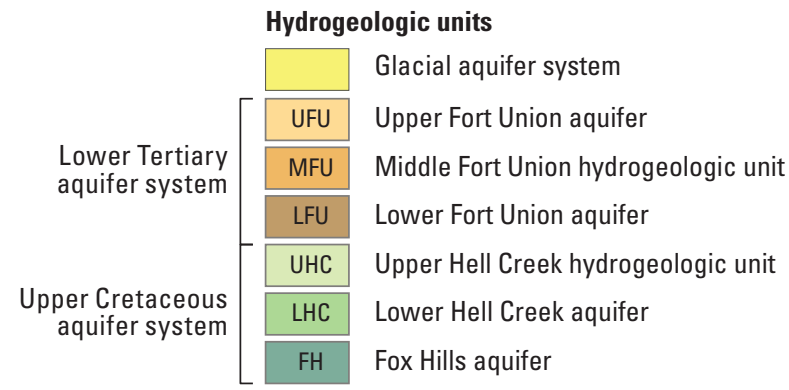

Figure 4. Hydrogeologic cross section $A-A^{\prime}$ showing the glacial, lower Tertiary, and Upper Cretaceous aquifer systems in the Williston Basin (from Long and others, 2014), United States and Canada. Location of cross section $A-A^{\prime}$ is shown in figure 1.

The glacial aquifer system consists of Quaternaryage unconsolidated till, silt, clay, outwash sand and gravel, and occasional cobbles and boulders. Reeves and others (2017) provided a generalized hydrogeologic framework and groundwater budget for the glacial aquifer system of the United States. Estimated volume of the glacial aquifer system in the study area is 150 trillion cubic feet $\left(\mathrm{ft}^{3}\right.$; Thamke and others, 2014). Widely varying lithologic characteristics result in an aquifer system that is characterized by multiple disconnected, locally productive sand and gravel aquifers buried beneath till and other glacial or surficial deposits and typically located in pre-glacial valleys that exist on the buried bedrock surface (Kehew and Boettger, 1986; Cummings and others, 2012; Pugin and others, 2014; Thamke and others, 2014). Thickness of the glacial aquifer system in the Williston Basin varies locally; maximum thickness is estimated to be about $750 \mathrm{ft}$ and thickest in northern North Dakota and Canada (Thamke and others, 2014). Hydraulic characteristics of the glacial aquifer system vary widely because of highly variable lithology. Hydraulic conductivity values estimated by Thamke and others (2014) for the glacial aquifer system range from 0.01 to 25 feet per day, varying more than for the lower Tertiary and Upper Cretaceous aquifer systems.
Davis and Long (2018a) separated the glacial aquifer system into two layers and subdivided these layers horizontally to represent different materials present in the glacial drift on the basis of geologic maps, aquifer maps, borehole logs, and locations of buried pre-glacial valleys. The upper layer was subdivided into three material zones: (1) low-permeability material consisting of till; (2) mediumpermeability material consisting of glaciolacustrine and glaciotectonic deposits; and (3) high-permeability material consisting of glaciofluvial, loess, and eolian deposits. The lower layer was subdivided into two material zones: (1) low-permeability material consisting of till and (2) highpermeability material consisting of sand and gravel that filled pre-glacial valleys. These valley-fill aquifers may be covered by different materials of low, medium, or high permeability. The spatial distribution of these five glacial-material zones is shown in Davis and Long (2018a). Additional background on glacial geomorphology is described in Aber and others (1989), Benn and Evans (1998), and Hart and Boulton (1991). Other geologic and hydrologic terms are described in Bates and Jackson (1984) and Wilson and Moore (1989). 
The remainder of this section is summarized from Thamke and others (2014). The lower Tertiary aquifer system in the Williston Basin consists of the upper and lower Fort Union aquifers separated by the middle Fort Union hydrogeologic unit (fig. 2). The lower Tertiary aquifer system is as thick as $2,250 \mathrm{ft}$, and estimated volume is 1,000 trillion $\mathrm{ft}^{3}$ in the Williston Basin. Rocks composing the lower Tertiary aquifer system represent many depositional environments, most commonly continental depositional environments (fluvial, deltaic, tidal, and barrier-shoreface) and less commonly marine depositional environments (Flores and Bader, 1999).

The upper Fort Union aquifer is as thick as $1,920 \mathrm{ft}$ and composed of crossbedded light-yellow to light-yellow-gray sandstone, sandy mudstone, gray shale, carbonaceous shale, and thick coal beds and associated clinker deposits (permeable rocks created by the natural burning of coal beds). Thickness of the upper Fort Union aquifer is greatest in the central part of the Williston Basin and thins at the edges where erosion has removed most of the unit (fig. 4).

Present throughout the central part of the Williston Basin, the middle Fort Union hydrogeologic unit thins toward the northeast and is not present in the northeastern one-third of the basin (fig. 4). Composed of as much as $520 \mathrm{ft}$ of thickness of alternating beds of sandstone, siltstone, mudstone, claystone, and lignite, rocks in the middle Fort Union hydrogeologic unit generally are finer-grained and darker-colored than the overlying upper Fort Union aquifer and underlying lower Fort Union aquifer. Because of spatially variable lithology, the middle Fort Union hydrogeologic unit may act as a confining unit in some areas and as an aquifer in other areas. The lower Fort Union aquifer is composed of as much as $670 \mathrm{ft}$ of thickness of yellow-weathering sandstones and light-grayweathering sandy mudstones interfingering with alternating brown and gray beds of sandstone, siltstone, claystone, mudstone, and lignite deposited in continental and marine environments.

The Upper Cretaceous aquifer system is the deepest and most areally extensive of the three aquifer systems and consists of, from top to bottom, the upper Hell Creek hydrogeologic unit, lower Hell Creek aquifer, and the Fox Hills aquifer (fig. 2). The volume of this aquifer system is about 1,000 trillion $\mathrm{ft}^{3}$ in the Williston Basin. The upper Hell Creek hydrogeologic unit is composed of as much as $740 \mathrm{ft}$ of thickness of alternating layers of gray and brown mudstone, siltstone, sandstone, and sparse lignite beds deposited by meandering streams with point bars and channel plugs. Because of spatial variability, this lithology may act as a confining unit in some areas and as an aquifer in other areas. The general lithology of the lower Hell Creek aquifer is similar to the upper Hell Creek hydrogeologic unit, except that the latter has a smaller percentage of sandstone. Streamchannel deposits and erosional surfaces are common in the lower Hell Creek aquifer (Flores, 1992), with a maximum thickness of as much as $550 \mathrm{ft}$ in the Williston Basin. The Fox Hills aquifer is the most areally extensive of the units, with as much as $420 \mathrm{ft}$ of thickness of interbedded sandstone, siltstone, and mudstone.

\section{Modeling}

\section{Conceptual Model of Groundwater Flow}

Average long-term precipitation recharge (1985-2011) for the study area ranges from 0 to about $10 \mathrm{in} / \mathrm{yr}$ (Long and others, 2014), generally with low values in the west and high values in the east. Precipitation in the form of snow primarily is stored during winter and infiltrates during spring melting periods. Groundwater recharge in the study area also results from stream reaches that lose flow as they infiltrate the ground and reservoir water that potentially seeps into the ground (Whitehead, 1996; Aurand, 2013; Bednar, 2013; Long and others, 2014). Groundwater loses flow to streams and reservoirs by exfiltration through the streambed material or reservoir sediments (Long and others, 2014). Exfiltration to streams provides important base flow that sustains many streams during dry seasons (fig. 5).

Long and others (2014) estimated the groundwater-flow budget, or balance of total groundwater inflows and outflows, for a control volume within the study area; this control volume was defined as a volume of the earth consisting of the lower Tertiary and Upper Cretaceous aquifer systems and the glacial aquifer system directly overlying these bedrock aquifer systems in the Williston Basin. Davis and Long (2018a) modified this control volume slightly near the Miles City arch (fig. 1). The base of the Upper Cretaceous aquifer system within the active model area (fig. 1) defines the horizontal extent and bottom of the control volume, and the land surface defines the top.

The glacial aquifer system contains productive buried sand and gravel aquifers that are the source of water for thousands of shallow wells (Whitehead, 1996; Long and others, 2014). The glacial aquifer system has a wide range of hydraulic conductivities and is characterized by disconnected local flow systems. The underlying bedrock aquifers commonly are under confined or partially confined conditions, except along the basin margins or in the shallowest aquifers (Long and others, 2014). Groundwater flow is exchanged, in both directions, between the glacial aquifers system and the underlying bedrock aquifers (Davis and Long, 2018a). Groundwater flow in the study area, particularly in the deeper aquifers, generally is from west and southwest to east, where discharge to streams and springs occurs; in the shallower aquifers, however, groundwater flow largely is controlled by land-surface topography, with steeper potentiometric surfaces than in the underlying aquifers (Long and others, 2014). Further descriptions of groundwater flow characteristics are in section, "Comparison of Conceptual and Numerical Models." 


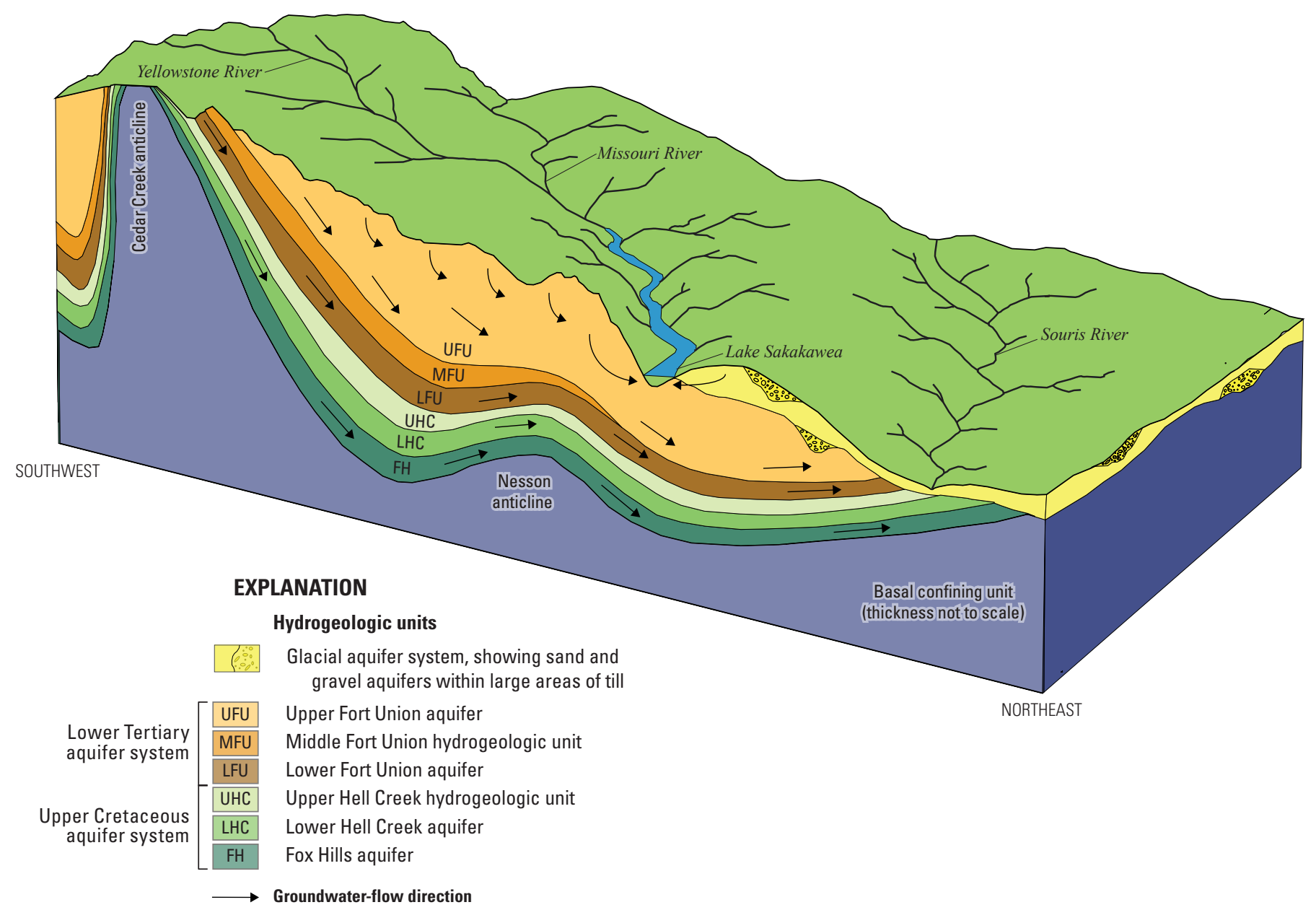

Figure 5. Groundwater flow in the Williston Basin, United States and Canada (modified from Long and others, 2014).

Declining groundwater levels resulting from continuously flowing artesian wells have occurred in the Fox Hills and lower Hell Creek aquifers; these wells, installed for domestic and agricultural use, flow continuously because of hydrostatic aquifer pressure (Fischer, 2013; Montana Department of Natural Resources and Conservation, 2014; North Dakota State Water Commission, 2015). Fischer (2013) described 521 flowing artesian wells in North Dakota that are open to the Fox Hills and lower Hell Creek aquifers, primarily near the Yellowstone, Little Missouri, and Knife Rivers (fig. 1). Flowing artesian wells may have, in part, caused groundwaterlevel declines of about 1 foot per year ( $\mathrm{ft} / \mathrm{yr}$ ) since the 1970s in the Fox Hills and lower Hell Creek aquifers near the Yellowstone River (Smith and others, 2000; Fischer, 2013).
Collectively, these wells were estimated to have a total flow rate of about $1.6 \mathrm{ft}^{3} / \mathrm{s}$ in 2008 on the basis of direct flow measurements from a subset of the wells (Fischer, 2013). However, because of uncertainty of this estimate, Fischer (2013) applied numerical modeling to improve the estimate and to better estimate the discharge from individual wells, including unmeasured wells. The total simulated withdrawal for all pumped and flowing artesian wells combined was in the range of 3-6 times higher than that originally estimated by Fischer (2013) for 1980-2008. Because most of the uncertainty in groundwater withdrawal is associated with the flowing artesian wells, numerical modeling indicates that the original estimate of $1.6 \mathrm{ft}^{3} / \mathrm{s}$ probably was low. 


\section{Summary of Numerical Modeling}

Two calibrated numerical groundwater-flow models were described by Davis and Long (2018a), and the digital files associated with the models are available in Davis and Long (2018b). The first model represents average hydrologic conditions for 1981-2005 executed in steady-state mode (Harbaugh, 2005) and is referred to as the "steady-state model" in this report. The second model was calibrated to temporally varying conditions for 1961-2005 and is referred to as the "transient model" in this report. The main purpose of the steady-state model was to provide a structure and starting point for the transient model. The transient model was designed to be a tool for forecasting the outcomes of different hydrologic scenarios. Thamke and others (2014) provided the bedrock hydrogeologic framework and initial (uncalibrated) aquifer-property values that were used in numerical modeling. Long and others (2014) described a conceptual model of groundwater flow, including a groundwater-flow budget, that provided a basis for numerical modeling. Another purpose of the steady-state model was to test this conceptual model and to calibrate many of the adjustable parameters, such as hydraulic conductivity, the values of which were then used in the transient model (Davis and Long, 2018a).

The transient model is not fully continuous with respect to time but rather represents distinct blocks of time called "stress periods," within which all specified model inflows are constant. All model output in this report represents the end of each stress period. The transient model consists of an initial steady-state stress period to simulate a long-term period prior to 1961 when groundwater withdrawals were small; this is referred to as the "predevelopment period" in this report. Following this predevelopment stress period are four 5-year stress periods representing calendar years 1961-65, 1966-70, 1971-75, and 1976-80, which are followed by 25 annual stress periods representing each of the calendar years, 1981-2005. This transient model was used in this study to simulate groundwater responses to hydrologic scenarios involving flowing artesian wells, drought, and increased groundwater withdrawal, which are described in sections that follow. These scenarios were simulated by adding additional stress periods to the transient model and thereby extending the simulation period through 2035.

The steady-state and transient models had identical spatial dimensions and grid layout (Davis and Long, 2018a). The model grid in the horizontal dimension consisted of square cells, about 1 mile (mi) (1,600 meters) on each side, with a total of about 657,000 cells in the active model area. The models consisted of eight layers: two layers representing the glacial aquifer system (layers 1 and 2) and six layers representing the six underlying bedrock hydrogeologic units (layers 3-8) (figs. 4, 5).

\section{Assessing Groundwater Availability}

Groundwater availability of a regional groundwater system is complex, dependent of many interconnected and uncertain factors. These factors include climate variability, human use of groundwater, complex aquifer characteristics, continual changes in groundwater storage, and changes in the ease of extracting groundwater. For example, aquifers that are highly productive but small in volume are most vulnerable to severe dewatering if local water demands are high. The groundwater stored in a regional aquifer overall might be minimally affected by local groundwater withdrawal but heavily affected locally in the withdrawal area. If the saturated zone of an unconfined aquifer is several hundred feet thick, a lowered water table might cause minimal change as a fraction of total groundwater storage but leads to other problems, such as (1) reduced streamflow and lake levels because of reduced groundwater input; (2) increased difficulty extracting groundwater from the deepening source; (3) possible decreased water quality at deeper levels; and (4) possible aquifer compaction resulting from reduced hydrostatic pressure in the aquifer's structural matrix (Anderson and Woosley, 2005; Barlow and Leake, 2012). Confined aquifers are affected in similar ways. The total volume of groundwater stored in a confined or unconfined aquifer may be of interest to some water managers but provides little information that is useful for managing groundwater because of the aforementioned problems.

A groundwater-flow budget that quantifies all inflows and outflows for the overall groundwater system is a valuable starting point to assess groundwater availability for human and ecological needs. The change in groundwater storage that results from changing inflows and outflow is a useful metric to assess the long-term sustainability of an aquifer, and a monthly or annual groundwater-flow budget provides an estimate of this metric. A groundwater-flow budget also is useful for comparing the relative flow magnitudes of different inflows and outflows. Because natural inflows to an aquifer generally are balanced by natural outflows, consumptive groundwater use ideally should be small in comparison to total groundwater recharge for long-term sustainability.

Quantification of the hydrogeologic framework defines the properties and characteristics of an aquifer system and can be used, along with a groundwater-flow budget, to develop a conceptual understanding, or model, of groundwater flow. The hydrogeologic framework, groundwater-flow budget, and conceptual model described by Long and others (2014) and Thamke and others (2014) were used to construct a numerical model of groundwater flow (Davis and Long, 2018a). To assess groundwater availability in the Williston Basin, this model was used to assess changes in groundwater storage and groundwater levels that potentially would result from human activity and climate variability. 


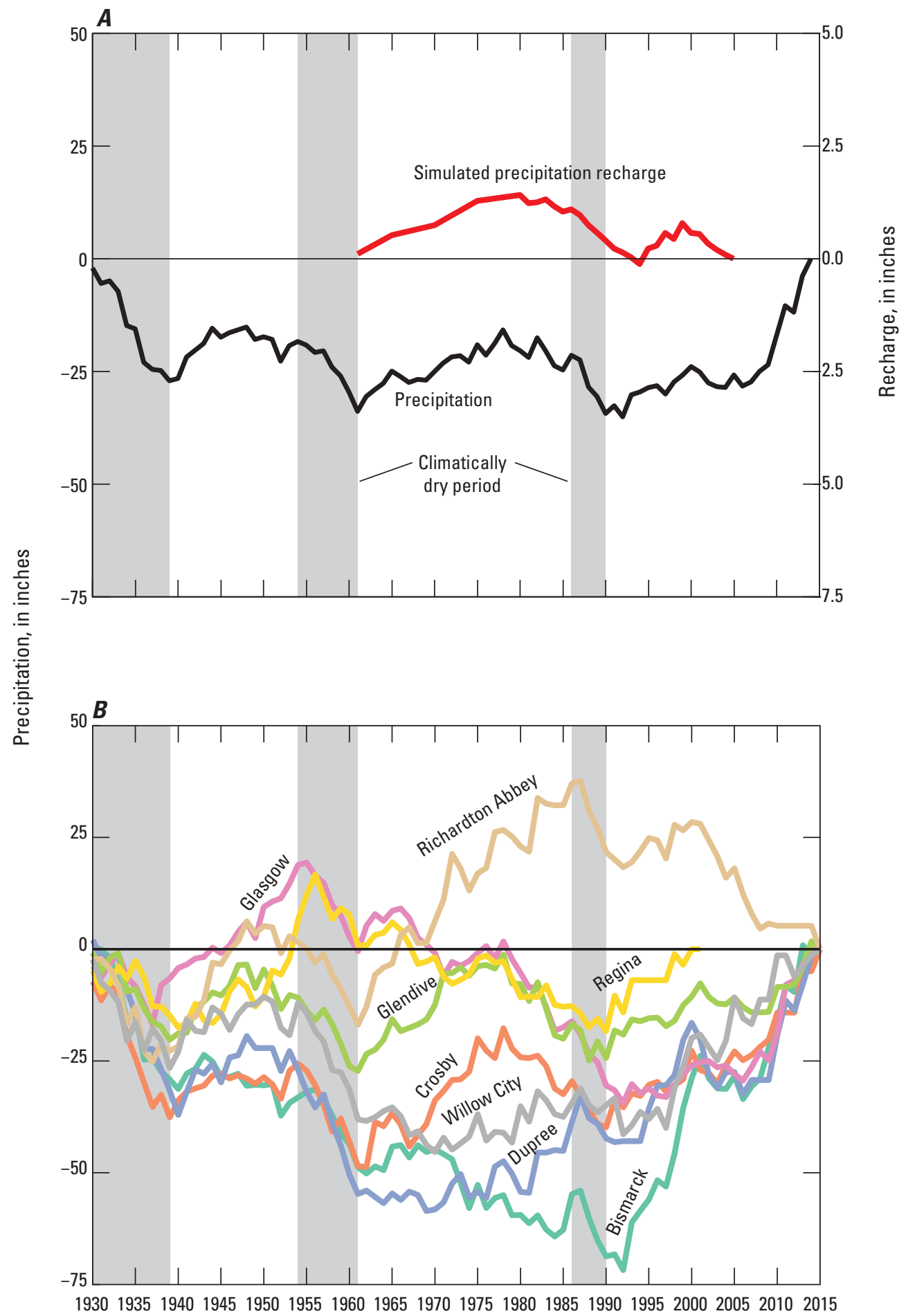

Figure 6. Annual cumulative departure from the mean for $(A)$ precipitation and simulated precipitation recharge as a spatial average within the active model area (Davis and Long, $2018 \mathrm{~b})$, and (B) precipitation for selected weather stations. Climatically dry periods are shown in gray. Weather station locations are shown in figure 7. 


\section{Analysis of Precipitation and Recharge}

An analysis of precipitation patterns indicates that climate within the study area is characterized by large spatial and temporal variation. An analysis of the annual cumulative departure from the mean (ACDM) for precipitation is one way to visualize multi-year or decadal pattern in precipitation rates across the study area. The ACDM, representing the spatial average of spatially-distributed (or gridded) annual precipitation estimates for the study area, was calculated for 1930-2014 (fig. 6A). The ACDM is the cumulative summation through time of the positive or negative difference between each annual precipitation value and the long-term mean, or average, value. Daily precipitation values from the PRISM Climate Group (Northwest Alliance for Computational Science and Engineering, 2018) averaged over the study area were accessed through the USGS GeoData Portal (U.S. Geological Survey, 2018). However, the PRISM data were not available for the Canadian part of the study area. Maurer and others (2002) provided a similar dataset with spatially distributed precipitation estimates for the entire study area, including Canada, but for a shorter period (1950-99). Because comparison of total annual precipitation for these two datasets indicates similarity, PRISM data were used to assess long-term changes by analysis of the ACDM (fig. 6A), which represents the United States only.

Downward slopes in the ACDM (fig. $6 \mathrm{~A}$ ) result from multiple years of below-average precipitation, whereas upward slopes indicate wet periods. Three distinct dry periods that lasted at least 4 years since 1930 are evident for periods where the slope of the ACDM for precipitation is relatively steep and downward overall (fig. 6A). These periods consist of most of the 1930s, the late 1950s, and the late 1980s. The wettest periods include the early 1940s, the early 1960s, and 2007-14.

The ACDM for simulated groundwater recharge has less interannual variability than the ACDM for precipitation (fig. 6A), which indicates that the soils store infiltrating precipitation for periods long enough to damp the variability of precipitation that becomes recharge. The volume of recharge is much less than the volume of precipitation as a result of evapotranspiration and direct runoff, which is evident in figure $6 \mathrm{~A}$, where the $\mathrm{ACDM}$ for recharge is exaggerated by a factor of 10 in relation to precipitation.

The ACDM was calculated individually for eight weather stations in the study area (figs. $6 B, 7$ ). Daily precipitation values for climate stations in the study area for 1930-2006 were available from the Global Historical Climatology Network (National Oceanic and Atmospheric Administration, 2018b). These data were supplemented with precipitation data for the same stations from Climate Data Online (National Oceanic and Atmospheric Administration, 2018a) to extend the period of record to 2015 . The daily values were used to calculate ACDM for each station for 1930-2014 (fig. 6B). There are spatial differences in the occurrence of wet and dry periods between the northwest and southeast parts of the study area. However, all the stations experienced mostly dry years during the three dry periods that were indicated for the spatial average (fig. 6A). The Glasgow and Regina stations in the northwest experienced wet conditions during the 1940s and early 1950s, compared to the other stations. The Richardton Abbey station overall was most different from the other stations, particularly after 1975, where the ACDM generally increased until 1987 and decreased until 2015. The Bismarck station was almost opposite to the Richardton Abbey station after 1961 .

A map of the long-term precipitation rate indicates a large change in total precipitation from west to east but less change from north to south (fig. 7), which is similar to the spatial distribution of groundwater recharge (Long and others, 2014). Differences in the ACDM for precipitation between stations indicate that temporal patterns of precipitation are related to the spatial distribution of precipitation. A spatio-temporal analysis of precipitation, therefore, provides insight by proxy into the spatio-temporal characteristics of groundwater recharge.

Consistent with the spatial distribution of precipitation are the ACDM curves for the weather stations, which also have more variability from west to east than from north to south (figs. $6 \mathrm{~B}, 7$ ). Furthermore, the timing of dry and wet periods is not consistent everywhere in the study area. For example, the Glasgow and Regina stations, located farthest to the northwest, overall have similar ACDM curves; however, the Glendive and Crosby stations have similar curve characteristics that differ from Glasgow and Regina (fig. 6B). The next station to the east, Richardton Abbey, has a unique ACDM and might represent a climatic transition from west to east. Separating these weather-station groupings into categories of climatically "driest," "moderately dry," "moderate," "moderately wet," and "wettest" helps to visualize this pattern in relation to the long-term precipitation map (fig. 7). Although the Willow City and Dupree stations are spaced far apart, they have similar ACDM characteristics and are in the "moderately wet" zone. The Bismarck station, in the "wettest" zone, also differs from the other stations. Therefore, the ACDM curves for the weather stations indicate climatic differences from west to east but similarities from north to south; this is consistent with long-term average precipitation that has a gradient from west to east. 


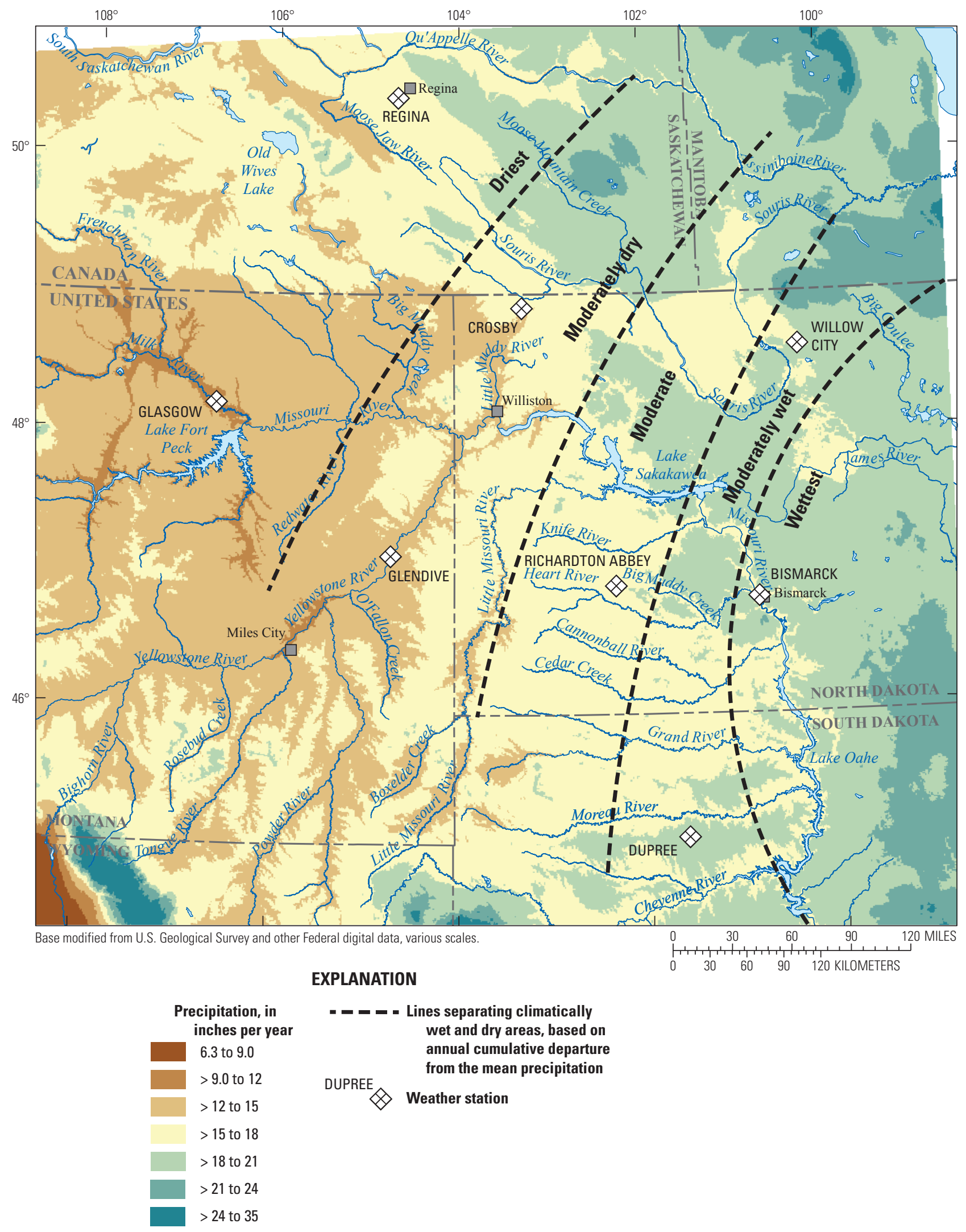

Figure 7. Locations of weather stations and long-term precipitation (1981-2011) data in the study area, Williston Basin, United States and Canada. Precipitation data from Long and others (2014). 


\section{Comparison of Conceptual and Numerical Models}

A comparison of the groundwater-flow budget from the conceptual model (Long and others, 2014) and the steadystate numerical model (Davis and Long, 2018a) serves as a qualitative evaluation of both models because these models should be reasonably consistent. Differences between these two groundwater-flow budgets help to quantify the range of uncertainty of both budgets (table 1).

\section{Groundwater Flow}

Long and others (2014) described general groundwaterflow directions and other characteristics within the context of an overall conceptual model of the study area. In this description, the estimated potentiometric surfaces for aquifers near the land surface closely resemble the undulating land topography, and flow directions are from upland areas toward streams. In the deepest aquifers, groundwater flows from southwest to northeast, with minimal influence from the land surface and has a smoother potentiometric surface. The lower Fort Union aquifer, with a middle range of depth among the three bedrock aquifers, has a potentiometric surface with characteristics that are a mixture of the deeper and shallower bedrock aquifers. Davis and Long (2018a) showed that the steady-state model simulated characteristics similar to those described by the conceptual model and further quantified similarities and differences of simulated and measured hydraulic-head values, spatially and temporally. Estimated groundwater-flow directions for the upper Fort Union aquifer, lower Fort Union aquifer, and Upper Cretaceous aquifer system were visually similar to simulated flow directions (Long and others; 2014; Davis and Long, 2018a).

Long and others (2014) did not provide a potentiometric surface for the glacial aquifer system, which therefore cannot be compared with the numerical model. However, the numerical-model simulation results are consistent with the locations of permitted groundwater wells in North Dakota, available from the North Dakota State Water Commission (2017). The numerical model generally simulated upland areas of the glacial aquifer system as unsaturated, where the simulated hydraulic head is below the bottoms of the cells (Davis and Long, 2018a), and the permitted wells generally are clustered in areas simulated as saturated. This indicates that modeling was consistent with the permit locations because water production wells would be in saturated areas where groundwater is available.

Table 1. Estimated and simulated average groundwater-flow budget for 1981-2005 within a control volume of the active model area.

[The last two columns show an alternate budget in which reservoir exfiltration is quantified as a net gain from groundwater, and reservoir infiltration is, therefore, zero (modified from Davis and Long, 2018a). Percent: The percentage of total recharge or total discharge. The totals may not add to 100 due to rounding. Abbreviations: $\mathrm{ft}^{3} / \mathrm{s}$, cubic foot per second; - , not estimated; $<$, less than]

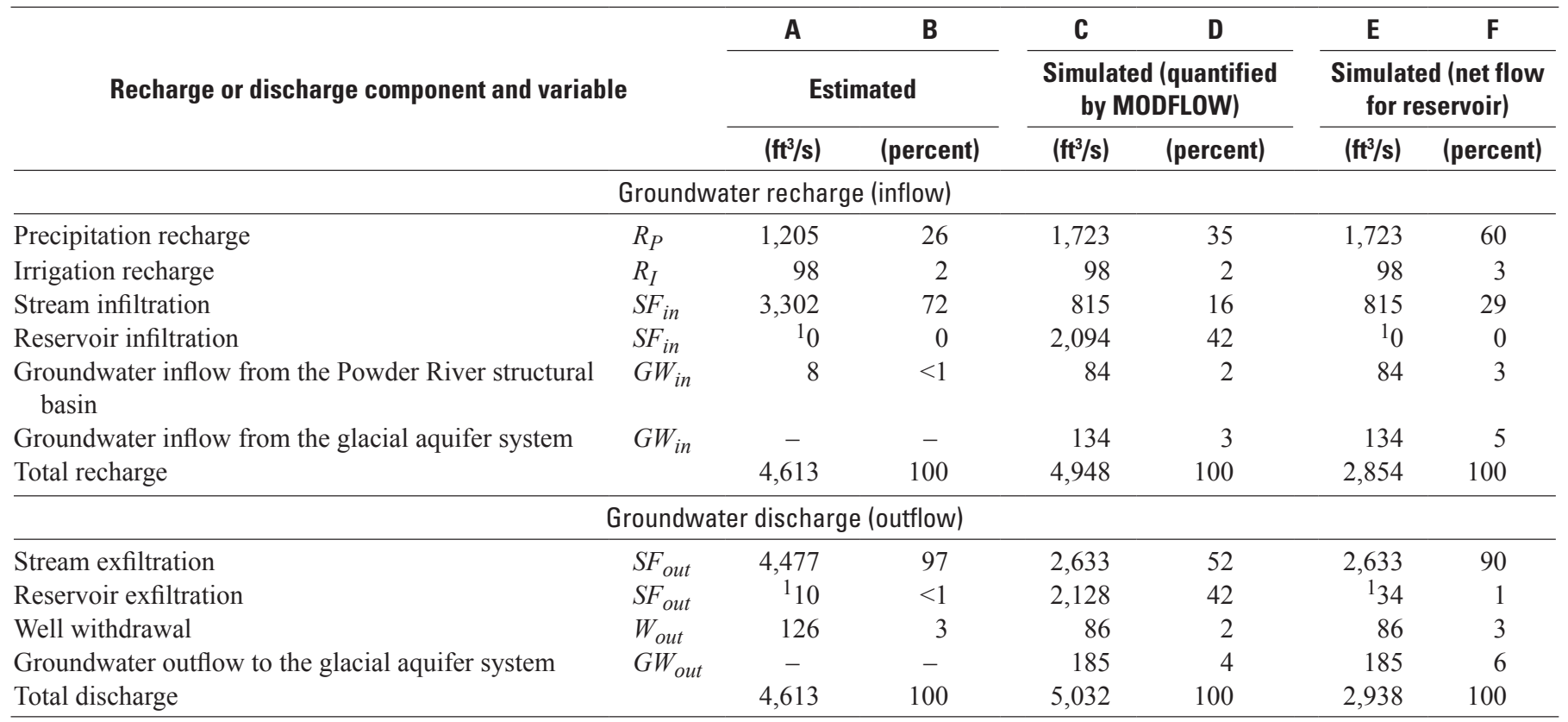

\footnotetext{
${ }^{1}$ Assumes a net value for groundwater infiltration and exfiltration.
} 


\section{Average Groundwater-Flow Budget}

The groundwater-flow budget is described by equation 1 , in which inflows and outflows are assigned positive and negative values, respectively.

$$
R_{P}+R_{I}+S F_{\text {in }}+G W_{\text {in }}+S F_{\text {out }}+G W_{\text {out }}+W_{\text {out }}+\Delta S=0
$$

where

$$
\begin{aligned}
& R_{P} \quad \text { is precipitation recharge; } \\
& R_{I} \quad \text { is irrigation recharge (excess irrigation that } \\
& \text { infiltrates the aquifer); } \\
& S F_{\text {in }} \quad \text { is stream and reservoir infiltration to } \\
& \text { groundwater; } \\
& G W_{\text {in }} \quad \text { is groundwater inflow to the control volume; } \\
& S F_{\text {out }} \quad \text { is stream and reservoir exfiltration from } \\
& \text { groundwater; } \\
& G W_{\text {out }} \quad \text { is groundwater outflow from the control } \\
& \text { volume; } \\
& W_{\text {out }} \quad \text { is well withdrawal and flowing artesian wells; } \\
& \text { and } \\
& \Delta S \quad \text { is storage change (positive or negative). }
\end{aligned}
$$

Long and others (2014) estimated the groundwaterflow budget for average conditions for a 25 -year period (1981-2005), as illustrated conceptually in figure 8A. Because this control volume was slightly modified by Davis and Long (2018a), as previously described, the estimated budget also was adjusted for consistency with the modified control volume (column A, table 1). Long and others (2014) did not consider possible storage change $(\Delta S)$ over the 25-year period. Simulated groundwater-flow budgets presented herein for the predevelopment period through 2005 consist of values from Davis and Long (2018a). Similarly to the estimated groundwater-flow budget, the simulated groundwater-flow budget for average conditions is dominated by $S F_{\text {in }}$ and $S F_{\text {out }}$ and secondarily by $R_{P}$; minor components consist of $W_{\text {out }}$, $G W_{\text {in }}$, and $G W_{\text {out }}$ (fig. $8 B$; table 1 ). $R_{P}$ is a major forcing component that affects streamflow, which likewise affects $S F_{i n}$; the combination of $R_{P}$ and $S F_{i n}$ are the major forcings that affect $S F_{\text {out }}$. Consequently, $R_{P}, S F_{\text {in }}$, and $S F_{\text {out }}$ account for 94 percent of the pie-chart area for average conditions (fig. 8B). Of the three reservoirs in the study area, Lake Sakakawea is the only reservoir within the active model area (fig. 1).

Comparison of the estimated and simulated groundwaterflow budgets indicates noteworthy similarities and differences (table 1). Differences result primarily from limitations inherent in estimating and simulating regional-scale groundwater flow and help provide ranges of uncertainty in each flow component. Long and others (2014) estimated precipitation recharge for the entire study area by using the Soil-Water
Balance (SWB) model (Westenbroek and others, 2010). Davis and Long (2018a) initially applied these SWB estimates to the numerical model and then adjusted the original estimates upward during model calibration; this increase was supported by comparison to two other recharge estimation methods for selected parts of the study area, in which the SWB estimates were at the lower range of estimates from the other methods (Aurand, 2013; Long and others, 2014). These methods were the chloride mass-balance and water-table-fluctuation methods (Healy and Cook, 2002; Healy, 2010). For the steady-state model (1981-2005), precipitation recharge was 1.4 times higher than the estimated value (columns $\mathrm{A}$ and $\mathrm{C}$, table 1).

Column $\mathrm{C}$ in table 1 consists of the simulated budget as quantified by MODFLOW and is the sum of all flows for each model cell for each flow category. For the reservoir component, column $\mathrm{C}$ indicates large values for reservoir infiltration and exfiltration, which are nearly balanced (column $\mathrm{C}$, table 1), because infiltration occurred for some reservoir cells and exfiltration occurred for others. Column E in table 1 shows results of an alternate way to quantify the simulated budget, one that is more consistent with the estimated budget. The estimated budget simplified the reservoir component by assuming a net reservoir exfiltration of $10 \mathrm{ft}^{3} / \mathrm{s}$ (column A, table 1), with no attempt to estimate infiltration and exfiltration for different areas of the reservoir. This results in a net value of zero for reservoir infiltration. If a net groundwater flow for the reservoir is applied to the simulated budget, the net reservoir infiltration and exfiltration is 0 and $34 \mathrm{ft}^{3} / \mathrm{s}$, respectively (column E, table 1), and the estimated and simulated values are similar -1 percent or less of total groundwater discharge (columns B and F, table 1).

An assessment of the recharge and discharge components as percentages of total recharge and discharge is a convenient way to compare the estimated and simulated groundwater-flow budgets (columns B and F, table 1). The long-term averages for estimated and simulated precipitation recharge were 26 and 60 percent, respectively, of total groundwater recharge. Estimated and simulated stream infiltration to groundwater were 72 and 29 percent, respectively, of all groundwater recharge. Estimated and simulated stream exfiltration from groundwater into streams were 97 and 90 percent, respectively, of all groundwater discharge. Although simulated stream infiltration was much lower than the estimated value (table 1), uncertainty of the estimate was large, partly resulting from uncertainty in consumptive use of surface water, which primarily occurs during the irrigation season (Long and others, 2014). Estimated stream exfiltration relied heavily on measured streamflow and base-flow estimates during the postirrigation season (Long and others, 2014) and, therefore, was minimally affected by consumptive use. 


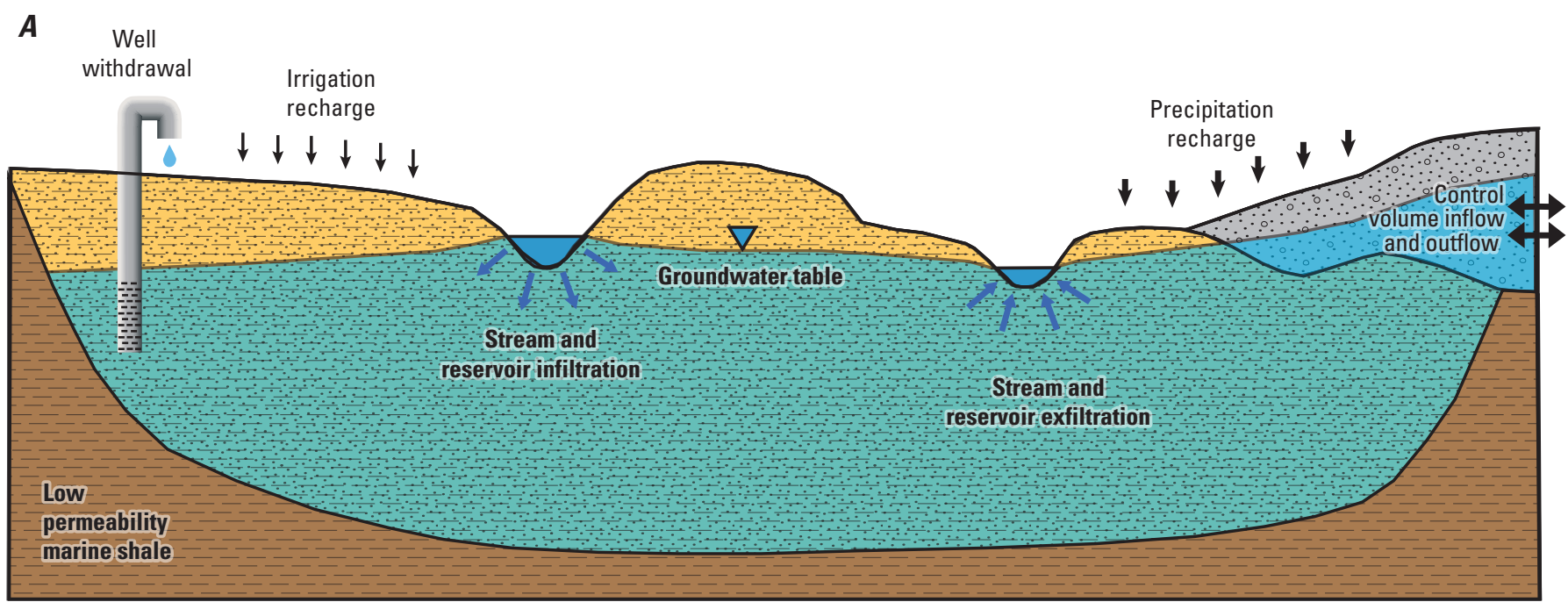

B
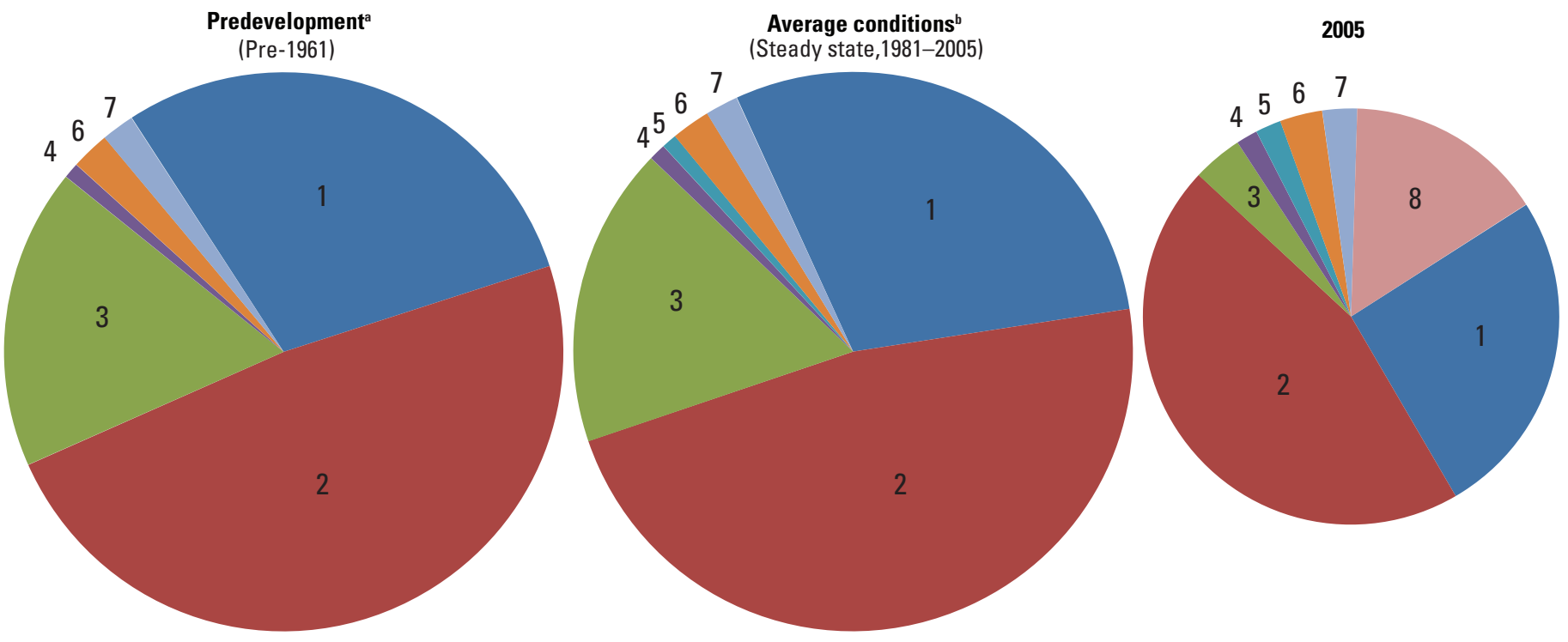

\section{EXPLANATION}

\section{Hydrogeologic units}

Glacial aquifer system

Lower Tertiary and Upper Cretaceous aquifer systems

Basal confining unit

Footnotes:

a. Predevelopment well withdrawal was not considered and is not shown on pie chart

b. Storage change is zero for steady state.

\section{Water budget pie charts}

- 1. Stream and reservoir infiltration $\left(S F_{i n}\right)$

- 2. Stream and reservoir exfiltration $\left(S F_{\text {out }}\right)$

3. Precipitation recharge $\left(R_{P}\right)$

- 4. Irrigation recharge $\left(R_{I}\right)$

5. Well withdrawal $\left(W_{\text {out }}\right)$

6. Groundwater inflow to the control volume $\left(G W_{i n}\right)$

- 7. Groundwater outflow from the control volume $\left(G W_{\text {out }}\right)$

8. Storage change $(\Delta S)$

Figure 8. Simulated groundwater-flow budget, Williston Basin, United States and Canada. (A) Conceptual profile of the groundwater system; $(B)$ relative magnitudes of water-budget components for predevelopment (pre-1961), average conditions (steady state, 19812005), and 2005. This groundwater-flow budget applies to the control volume. Values are from Davis and Long (2018b). 
Irrigation recharge is the excess irrigation that infiltrates the aquifer, for which the simulated and estimated values were identical, because this rate was specified in the model rather than calibrated. A relatively small amount $\left(8 \mathrm{ft}^{3} / \mathrm{s}\right)$ was estimated and simulated for groundwater flow from the Powder River Basin into the Williston Basin through connected hydrogeologic units (table 1). The glacial aquifer system extends beyond the limits of the control volume and, therefore, allows horizontal groundwater flow into and out of the control volume. The simulated groundwater inflow and outflow for the glacial aquifer system is 5 and 6 percent, respectively, of the simulated groundwater-flow budget (column F, table 1); the estimated counterparts of this inflow and outflow were assumed to be balanced (Long and others, 2014) and, therefore, not considered in the estimated groundwater-flow budget. Well withdrawal was a small part of the estimated and simulated groundwater-flow budget (table 1); the estimated value was reduced by 32 percent in the steady-state model (1981-2005) because of numerical instability during model calibration, as described by Davis and Long (2018a). However, this reduction of estimated well withdrawal was not applied to the transient model and, therefore, had no effect on simulating hydrologic scenarios.

Infiltration to groundwater from domestic on-site sewage treatment, or septic, systems also was considered. About 9 percent of all well withdrawals in the control volume are from domestic wells (Long and others, 2014). If as much as 90 percent of the domestic groundwater use is presumed to be diverted to septic systems, the infiltration from domestic septic systems would be less than 0.3 percent of total groundwater recharge. Even if the error in this estimate is large, the septicsystem infiltration rate would be small enough to neglect.

\section{Simulated Transient Groundwater-Flow Budget}

For transient simulations, storage change $(\Delta S)$ balances equation 1 so that the sum of all components equates to zero, and the sign of $\Delta S$ is determined on this basis. For example, if inflows exceed outflows, $\Delta S$ is negative and represents an increase in groundwater storage. The groundwater-flow budget for the predevelopment period differs little from that of average conditions (steady state, 1981-2005) because average well withdrawals for 1981-2005 were a small part of the total groundwater-flow budget (fig. $8 B$ ).

Simulated precipitation recharge for 2005 was small in comparison to that of average conditions (fig. $8 B$ ), which is consistent with below-average precipitation recharge for 2000-2005, as shown by a negative slope in the cumulative-departure curve (fig. $6 A$ ). Low precipitation recharge for 2005 resulted in total inflow that was only 69 percent as large as total outflow and, consequently, large storage-change, $\Delta S$ (fig. $8 B$ ).

A groundwater-flow budget for the transient model (predevelopment-2005) provides additional insight into hydrologic change, as well as differences in the three aquifer systems (fig. 9). The time increments in figure 9 are variable, with 5-year increments for 1961-80 and 1-year increments for 1981-2005. The total length of each bar represents the total magnitude of the groundwater-flow budget by stress period, which visually characterizes wet and dry periods; for example, 1995-99 was climatically wet and has the largest flows for all three aquifer systems. Generally, the wet and dry periods are visible and consistent for all three aquifer systems. These temporal changes are consistent with the cumulative departure from average precipitation recharge $\left(R_{P}\right)$ (fig. $\left.6 A\right)$ : 1961-75 had moderately above-average $R_{P} ; 1971-86$ had variable $R_{P}$ that was above and below average; 1987-94 represented low $R_{P} ; 1995-99$ represented high $R_{P}$; and 2000-2005 represented low $R_{P}$ (fig. 9). In each stress period, $\Delta S$ is either positive or negative, and if $R_{P}$ is high, total inflows generally are greater than total outflows, resulting in negative $\Delta S$ (increased storage); whereas, low $R_{P}$ corresponds to positive $\Delta S$ (decreased storage) (fig. 9).

Surface-water infiltration ( $S F_{i n}$, positive) and exfiltration $\left(S F_{\text {out }}\right.$, negative), shown in figure 9 , together are the largest component of the groundwater-flow budget. $S F_{\text {out }}$ is larger than $S F_{\text {in }}$ for all three aquifer systems, particularly for the Upper Cretaceous aquifer system where $S F_{\text {in }}$ is negligible.

The lower Tertiary aquifer system has the largest overall groundwater-flow budget and the greatest variability of the three aquifer systems. The Upper Cretaceous aquifer system has the smallest groundwater-flow budget and least variability (fig. 9); the small groundwater-flow budget partly results from a land-surface exposure that is areally small relative to the other two aquifer systems (fig. 1). The Upper Cretaceous aquifer system has, on average, a groundwater-flow budget that is less than one-third as large as the other two aquifer systems but accounts for about 70 percent of the total well withdrawals for the control volume (fig. 10); this largely is because flowing artesian wells discharging from the Upper Cretaceous aquifer system account for about 50 percent of all well withdrawals for the control volume (Davis and Long, 2018a). Groundwater pumped from the lower Tertiary and Upper Cretaceous aquifer systems was below average during 1996-2000 (fig. 10) because of high precipitation recharge (figs. 6, 9), which reduced demand. This high-recharge period also corresponds to a decrease in total well withdrawals as a percentage of groundwater inflow for the control volume, although this percentage has increased overall from the predevelopment period to 2005 (fig. 10). 


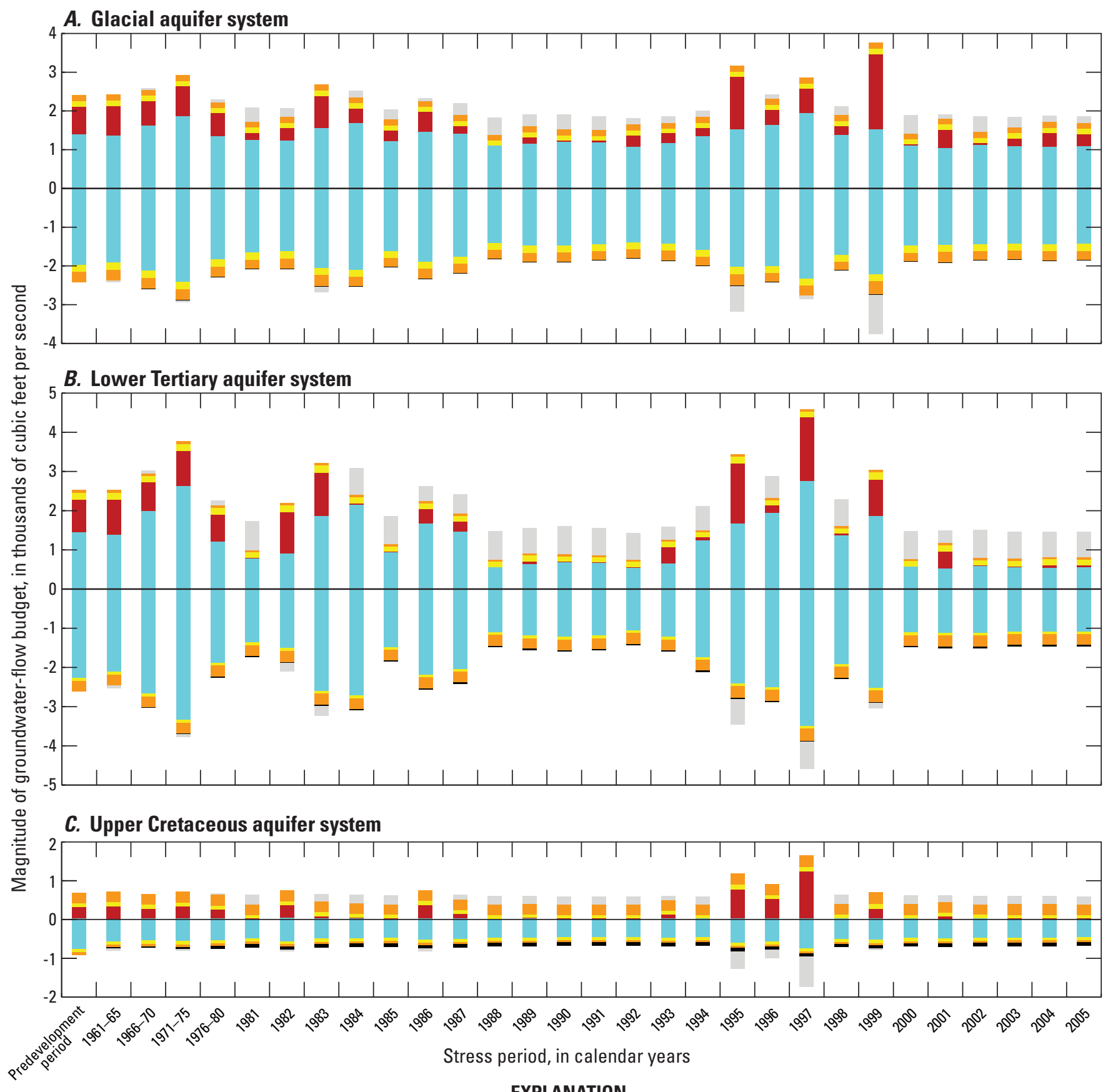

EXPLANATION

Surface-water infiltration (positive) and exfiltration (negative)

Precipitation and irrigation recharge

Inflow from (positive) and outflow to (negative) the glacial aquifer system
Inflow from (positive) and outflow to (negative) bedrock aquifer systems

Well withdrawal

Storage change

Figure 9. Simulated groundwater-flow budget by stress period (predevelopment-2005) for the $(A)$ glacial aquifer system, $(B)$ lower Tertiary aquifer system, and $(C)$ Upper Cretaceous aquifer system for the control volume, Williston Basin, United States and Canada. Values are from Davis and Long (2018b). 


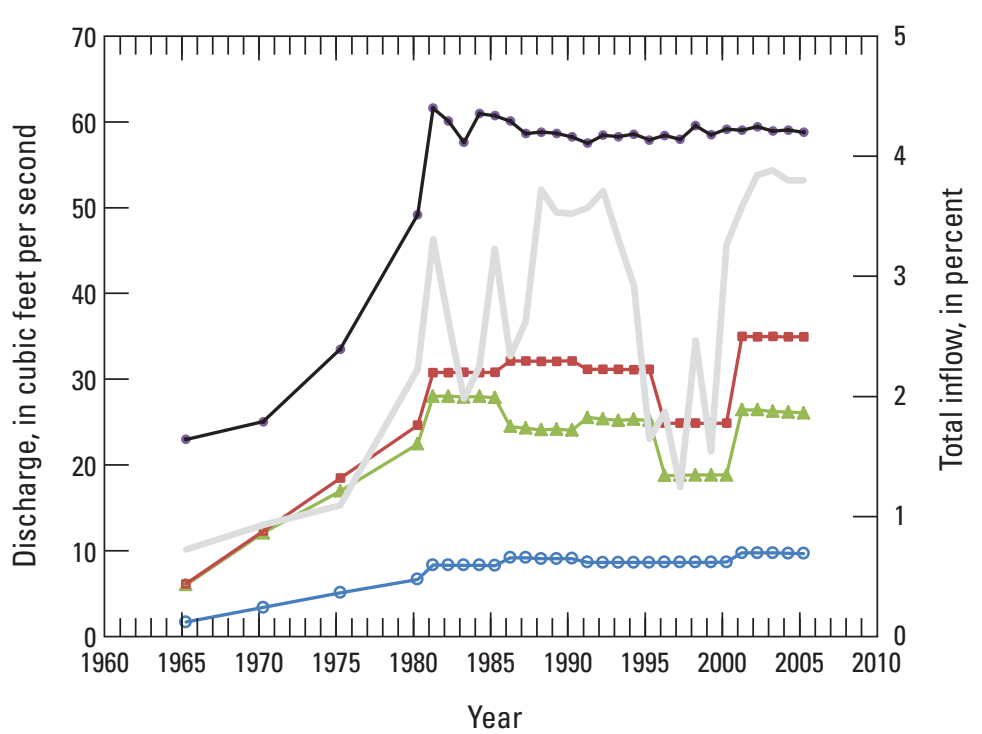

EXPLANATION

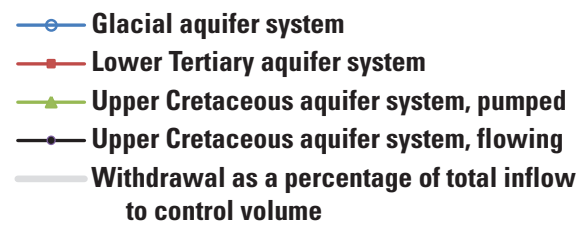

Figure 10. Groundwater withdrawals from wells, by aquifer system, Williston Basin, United States and Canada. Values from Davis and Long (2018b).

\section{Hydrology of Flowing Artesian Wells}

About 70 percent of the flowing artesian wells that were completed in the Fox Hills and lower Hell Creek aquifers were installed during 1960-90 (Fischer, 2013). Within most of the study area, groundwater levels generally were steady prior to 2000 (Thamke and others, 2014), but declining water levels have occurred locally in areas where flowing artesian wells are located because of their cumulative groundwater discharge. Near the Yellowstone River, flowing artesian wells contributed to groundwater-level declines of about $1 \mathrm{ft} / \mathrm{yr}$ since the 1970s in the Fox Hills and lower Hell Creek aquifers (Smith and others, 2000; Fischer, 2013). Hydraulic-head changes, mostly declines, were in these two aquifers near the Little Missouri River for 1994-2006 (Honeyman, 2007a, $2007 \mathrm{~b}, 2007 \mathrm{c}$ ). These rates of change ranged from -4.1 to $1.4 \mathrm{ft} / \mathrm{yr}$, with a mean rate of about $-1.28 \mathrm{ft} / \mathrm{yr}$, which was projected to result in wells ceasing to flow during 2007-93, depending on the well (Honeyman, 2007a, 2007b, 2007c). In addition to discharging to the land surface, flowing artesian wells near the Yellowstone and Little Missouri Rivers also might allow leakage into the overlying lower Tertiary aquifer system because of inadequate sealing or corrosion of well materials (Fischer, 2013) in combination with the upward hydraulic gradient that occurs in these areas (Long and others, 2014).

\section{Simulated Groundwater Response to Flowing Artesian Wells}

Hydrostatic pressure in the aquifer causes flowing artesian wells to flow without a pump. Fischer (2013) described flowing artesian wells in North Dakota, installed for domestic and agricultural use, that are open to the Fox Hills and lower Hell Creek aquifers of the Upper Cretaceous aquifer system. The wells primarily are near the Yellowstone, Little Missouri, and Knife Rivers, with additional flowing artesian wells near Lake Sakakawea (fig. 1). These wells are of concern because they generally are not capped or valved, resulting in continuous discharge of groundwater (Smith and others, 2000; Honeyman 2007a, 2007b, 2007c; Fischer, 2013). Flowing artesian wells also are located in parts of Montana (Wanek, 2009). To better understand the potential effects of flowing artesian wells into the future, a set of assumptions was selected and applied to a model scenario; however, many different assumptions could be made about the future, all of which would affect flowing artesian wells. This scenario is only one example of the many sets of assumptions that could be applied to test the effects of flowing artesian wells.

\section{Scenario 1: Flowing Artesian Wells}

Flowing artesian wells were simulated as head-dependent boundary cells (Davis and Long, 2018a); that is, the rate of well discharge is influenced by hydraulic head surrounding the well and, therefore, is similar to spring discharge. These wells were simulated as being open to the Fox Hills and lower Hell Creek aquifers. The transient model was used to assess potential outcomes if none of the flowing artesian wells were capped or plugged through 2035, with other conditions remaining constant. The simulation results provide estimates of (1) when flowing artesian wells might cease to flow because of hydraulic-head declines, and (2) the spatial distribution of hydraulic-head declines. Model input and output for this scenario are available from Davis and Long (2018c). Scenario 1 was executed for 1961-2035 and was identical to the original transient model for its simulation through 2005. Period 2006-35 was simulated with 1-year stress periods. To extend this simulation through 2035, precipitation-recharge rates and conditions for the MODFLOW Streamflow-Routing Package that were applied to the steady-state model were applied in the flowing-wells scenario at steady rates for 2006-35. The groundwater pumping rates that originally were 
applied to the 2005 stress period were applied in the flowingwells scenario at steady rates for 2006-35. This assumes no increased groundwater pumping for energy-resource production, which is highly uncertain into the future and, therefore, is a conservative approach. Applying these steady rates was an attempt to assess the effects of flowing artesian wells without interference from other changing hydrologic conditions; however, the assumptions made for the rates of pumping and other hydrologic conditions play a large role in the outcome. Because groundwater pumping is expected to continue long into the future to some degree, this scenario cannot isolate the effects of flowing artesian wells but is useful as a long-term assessment of flowing artesian wells, if it is assumed that groundwater pumping will continue.

All simulated flowing artesian wells were applied equally to the Fox Hills and lower Hell Creek aquifers, and results are summarized for the Fox Hills aquifer. Most of the simulated hydraulic-head decline for the Fox Hills aquifer occurred for the 1961-2005 period (fig. 11), but the simulation through 2035 showed that this drawdown area continued to enlarge after 2005 (fig. 12). Simulated declines were largest in areas near the Yellowstone, Missouri, and Little Missouri Rivers, where flowing artesian wells are located (fig. 12). Simulated hydraulic-head decline was as much as $170 \mathrm{ft}$ in some areas. Simulated and measured hydraulic head generally was inverse to simulated outflow from flowing artesian wells in areas where drawdowns occurred (fig. 13). The total rate of outflow for flowing artesian wells increased from 1965 to 1980 to a high of about $61 \mathrm{ft}^{3} / \mathrm{s}$, as the number of wells increased, and then varied between about 61 and $57 \mathrm{ft}^{3} / \mathrm{s}$ until 2003 (fig. 13). After 2003, when few additional wells were installed, the simulated outflow decreased to about $54 \mathrm{ft}^{3} / \mathrm{s}$ in 2035 ; this decrease in outflow was steepest for the 2006 stress period and gradually flattened through the remainder of the simulation, which is consistent with a flattening of the simulated hydraulic-head declines, particularly after 2010 (fig. 13). This simulation indicates that the installation of flowing artesian wells initiated the hydraulic-head declines, which then resulted in decreases in outflow rates because of decreasing hydraulic pressure within the wells, and that outflows were moving toward an equilibrium state with hydraulic head.

A second reason for the flattening of the simulated hydraulic-head decline was that many of the wells ceased to flow. The total number of flowing artesian wells established in the model was 571 (Davis and Long, 2018a), and of these, 271 wells did not flow at any time during the simulation because hydraulic head was always below the land-surface (fig. 12). As hydraulic head declined throughout the simulation, 68 of these wells responded by ceasing to flow by the end of 2005 , another 7 wells ceased flowing by the end of 2035, and the remaining 225 simulated wells continued to flow at the end of the simulation (fig. 12).
The simulated precipitation recharge for the 2006-35 period was high in relation to the earlier simulated period, which is another factor that partly resulted in a flattening of the hydraulic-head decline for that period (fig. 13). The average simulated recharge for 1981-2005 was $1,723 \mathrm{ft}^{3} / \mathrm{s}$, which is low in comparison to the value of $3,174 \mathrm{ft}^{3} / \mathrm{s}$ that was used for the steady-state model, as well as for the 2006-35 period in scenario 1 . The value of $3,174 \mathrm{ft}^{3} / \mathrm{s}$ for steady state was based on the average estimated recharge for the 1981-2011 period because this was considered to best represent the long-term average (Davis and Long, 2018a), and the last 6 years of this period (2006-11) were unusually wet years (fig. 6A). Another factor influencing the flattening of the hydraulic-head decline (fig. 13) is the simulated overlying aquifers that helped to buffer the decline by supplying groundwater inflow to the Fox Hills and lower Hell Creek aquifers as hydraulic pressure was reduced in those aquifers. Although scenario 1 indicates decreasing severity of hydraulic-head decline for the future, different scenarios also should be considered. For example, if other conditions prevail in the future - such as continued increase in groundwater pumping rates, drier climatic conditions, or long-term drought - then hydraulic-head declines would be larger than those indicated by scenario 1 .

Fischer (2013) took a somewhat different approach to simulate the Fox Hills and lower Hell Creek aquifers' hydraulic-head declines resulting from flowing artesian wells; this model consisted of one layer and flowing artesian wells that were simulated with specified flow rates, independent of hydraulic head. The result of this simulation was a decline of hydraulic-head values of as much as $200 \mathrm{ft}$ for 1942-2009 and as much as $55 \mathrm{ft}$ for a projected future scenario representing 2009-39.

As described in section, "Conceptual Model of Groundwater Flow," the total withdrawal for all pumped and flowing artesian wells combined was simulated by Fischer (2013) to be in the range of 3-6 times higher than what was originally estimated for 1980-2008; this increase for the numerical model was necessary to simulate the measured hydraulic-head declines near flowing artesian wells. One reason for numerical modeling was to improve the uncertain estimate of the total flow rate from flowing artesian wells of $1.6 \mathrm{ft}^{3} / \mathrm{s}$ (Fischer, 2013). Inadequate sealing or corrosion of these wells, which may result in leakage into the lower Tertiary aquifer system, contributes to this uncertainty (Fischer, 2013). For scenario 1 herein, the rate of flowing artesian wells was as high as $61 \mathrm{ft}^{3} / \mathrm{s}$, which also was much higher than the $1.6 \mathrm{ft}^{3} / \mathrm{s}$ originally estimated. Therefore, two different models indicate that the total flow rate from flowing artesian wells is much higher than $1.6 \mathrm{ft}^{3} / \mathrm{s}$. 


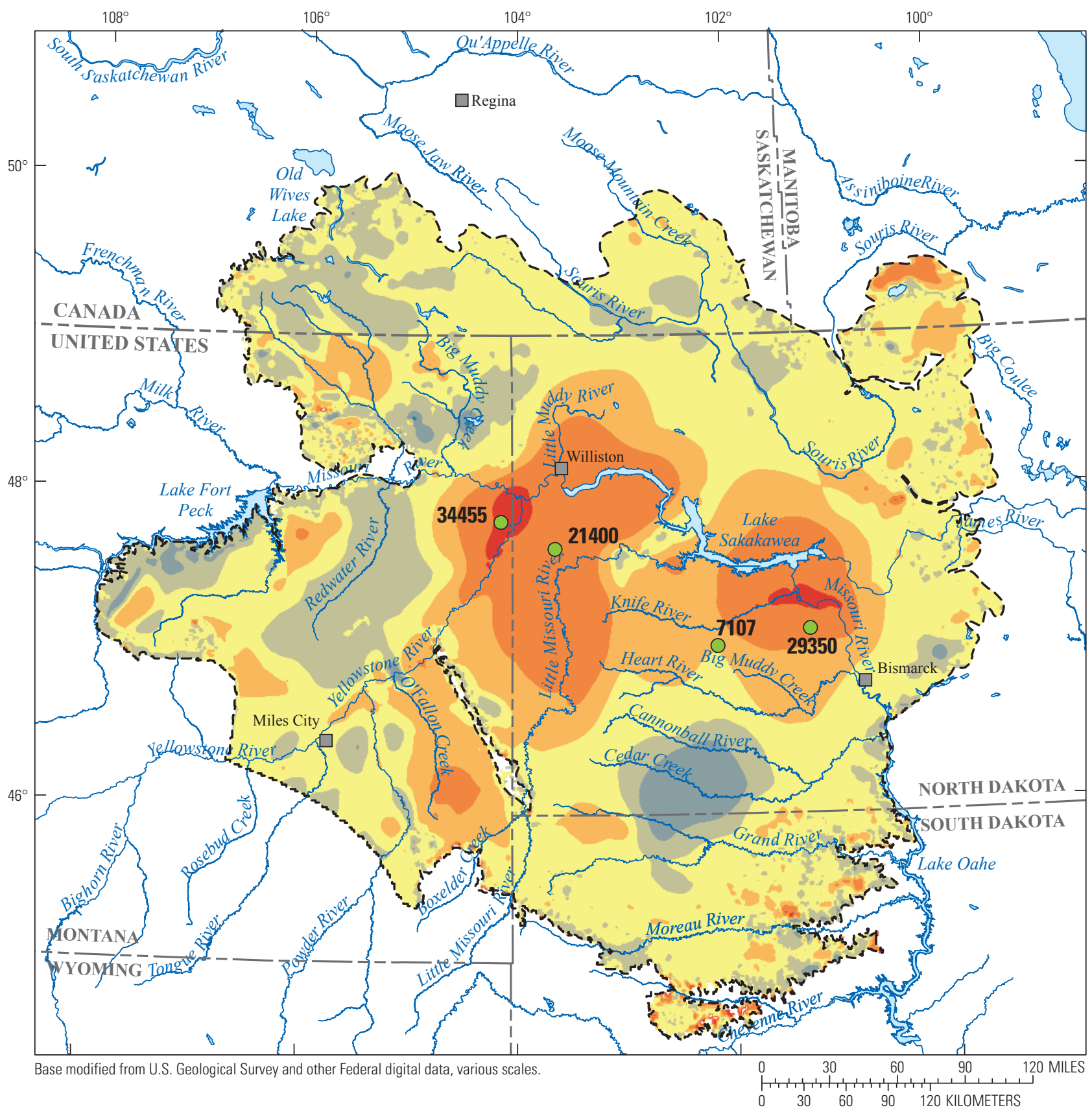

EXPLANATION

Change in simulated hydraulic head, Fox Hills aquifer (1961-2005), in feet. Negative values indicate head decline
Modeled extent of the Fox Hills aquifer

Hydraulic-head monitoring well

Figure 11. Scenario 1 simulated hydraulic-head change from 1961 to 2005 for the Fox Hills aquifer, Williston Basin, United States and Canada. 


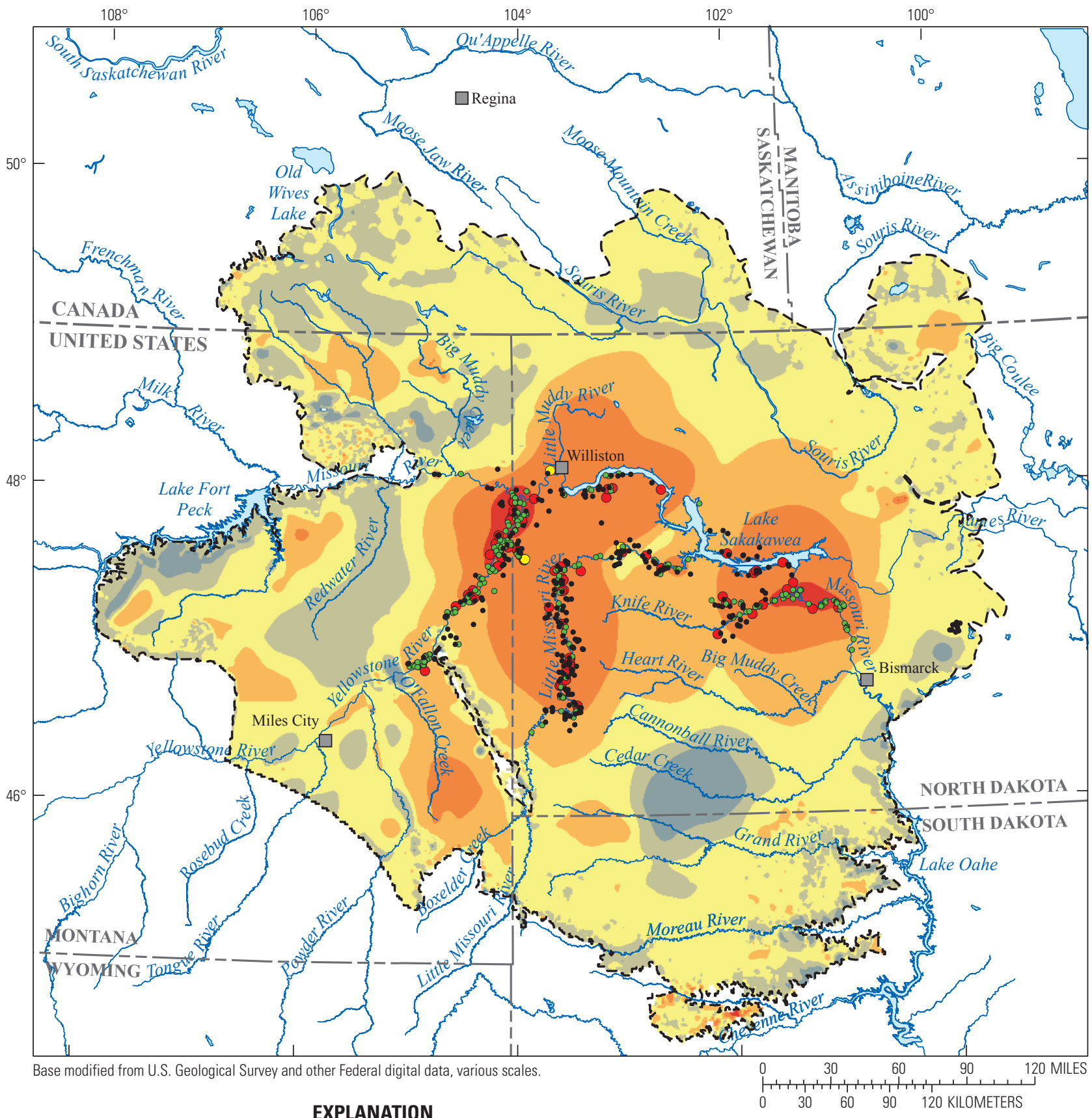

EXPLANATION

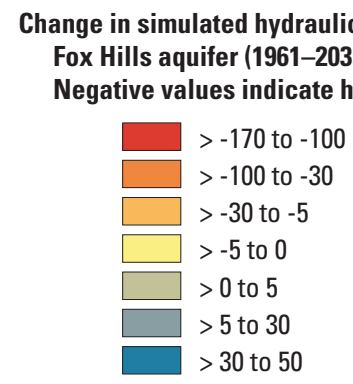

- - - Modeled extent of the Fox Hills aquifer

Simulated flowing artesian well

Well stopped flowing prior to 2005 (68 wells)

Well stopped flowing between 2005 and 2035 (7 wells)

Well that was flowing in 2035 (225 wells)

Well did not flow during the simulation period (271 wells)

Figure 12. Scenario 1 simulated hydraulic-head change from 1961 to 2035 for the Fox Hills aquifer, Williston Basin, United States and Canada. 


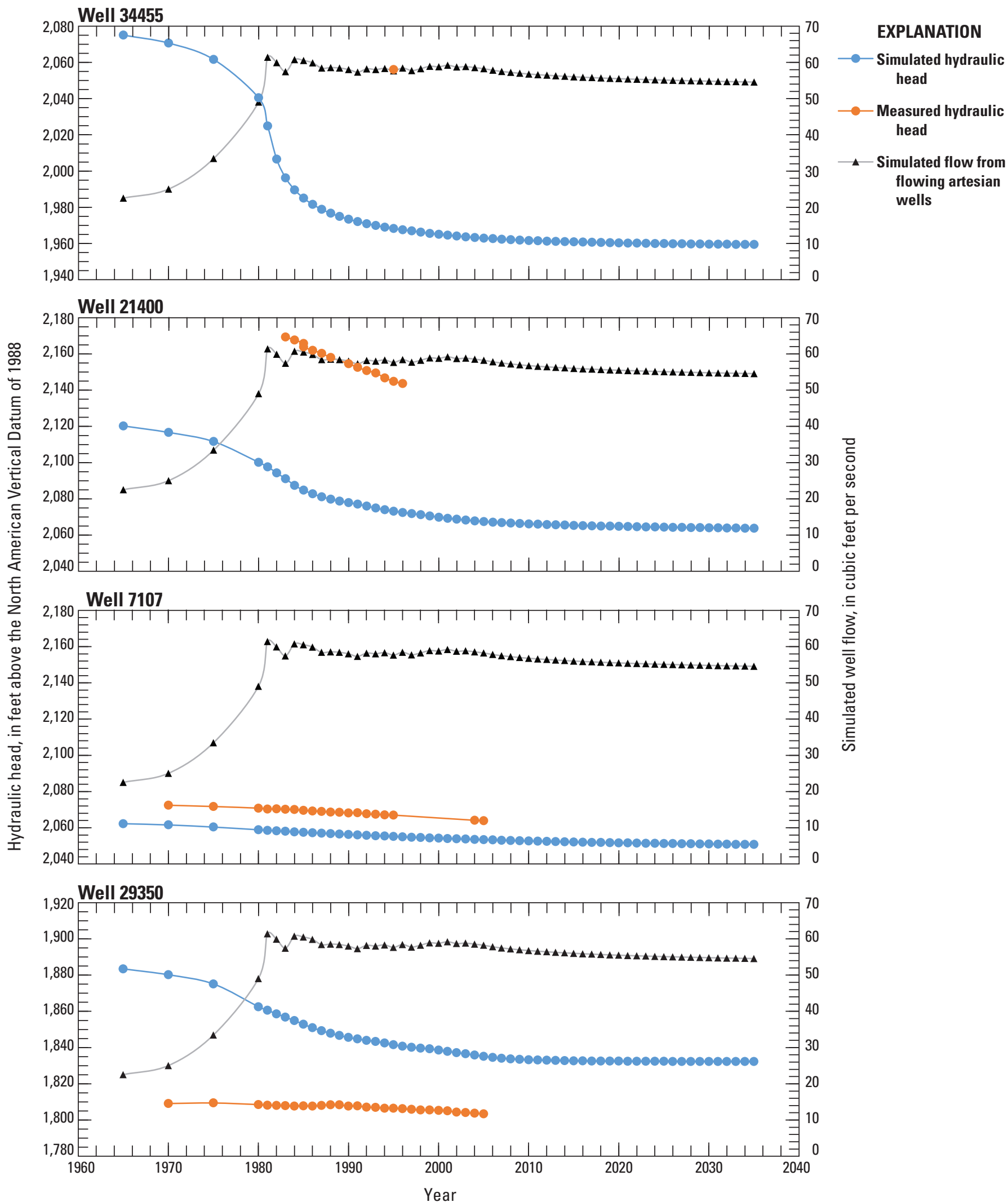

Figure 13. Scenario 1 simulated and measured hydrographs of hydraulic head for four monitoring wells open to the Fox Hills aquifer and total flow from flowing artesian wells, Williston Basin, United States and Canada. Locations of wells are shown in figure 11. 


\section{Simulated Groundwater Responses during Drought}

The increased freshwater demands for energy-resource production (ERP) from the Williston Basin were offset by precipitation rates that were higher than average during the 2006-15 period, as indicated by a steep increase in the annual cumulative departure from mean precipitation (fig. $6 A$ ). The resulting increases in streamflow and groundwater recharge allowed for the availability of temporary surface-water and groundwater permits in North Dakota (North Dakota State Water Commission, 2017). If, however, a drought had occurred during this period of increased groundwater withdrawal, how would this affect groundwater availability? To help answer this question, a hypothetical 10-year drought was simulated for 2006-15, and two groundwater-withdrawal scenarios were applied as a comparison (scenarios 2 and 3). Scenarios 2 and 3 offer additional example scenarios, but many other possibilities could be simulated with this model. Model input and output for these scenarios are available from Davis and Long (2018c).

\section{Scenario 2: Drought with Steady Groundwater Withdrawals}

Estimated annual groundwater recharge for 1987-91 was the lowest 5 years of the estimated record for 1981-2011 (Long and others, 2014). To simulate a drought, precipitation recharge and flow conditions for the Streamflow-Routing Package that were applied to the transient model (Davis and Long, 2018a) for 1987-91 were applied twice consecutively to simulate a 10 -year drought for the $2006-15$ period. To simulate steady groundwater withdrawals, the groundwater pumping rates that originally were applied to the 2005 stress period were applied in this scenario at steady rates for 2006-15, which represents pumping rates prior to large increases in water use for ERP.

For most of the western part of the active model area, simulated groundwater declines resulting from the 10-year drought were small, in the range of $0-1 \mathrm{ft}$, for the glacial aquifer system and the upper Fort Union aquifer (figs. 14, 15). In the eastern areas, simulated declines in the range of 1-5 ft were common, with more than $5 \mathrm{ft}$ of decline in many areas (figs. 14, 15). More than $200 \mathrm{ft}$ of simulated decline occurred for eastern parts of the glacial aquifer system (fig. 14). These results show the change from 2005 (the year prior to the simulated drought) to 2015 , when simulated precipitation recharge was 1,437 and $516 \mathrm{ft}^{3} / \mathrm{s}$, respectively, for the active model area. This is only a moderate decrease in recharge compared to the long-term average rate of $3,174 \mathrm{ft}^{3} / \mathrm{s}$ that was simulated in the steady-state model (Davis and Long, 2018a). The highest simulated precipitation-recharge rates were for $1995\left(5,846 \mathrm{ft}^{3} / \mathrm{s}\right), 1997\left(5,202 \mathrm{ft}^{3} / \mathrm{s}\right)$, and $1999\left(5,946 \mathrm{ft}^{3} / \mathrm{s}\right)$.
A drought simulation following any of these higher recharge rates would result in much larger groundwater declines.

Some of the central and western areas show groundwater increases, primarily in the range of $0-1 \mathrm{ft}$ (figs. 14, 15). This results from the spatio-temporal variability of precipitation, as described in section, "Analysis of Precipitation and Recharge." A noteworthy insight from this simulation is that the climatically wet eastern areas are more susceptible to groundwater declines during drought than are the dry western areas, and groundwater increases might occur in some western areas locally because of spatio-temporal variability.

\section{Scenario 3: Drought with Increased Groundwater Withdrawals}

This scenario was identical to scenario 2, except that increased groundwater withdrawals to supply the needs of ERP for 2006-15 also were applied. The freshwater used for ERP was estimated by two separate methods. The first method, the consumption estimate, focused strictly on the estimated freshwater needs for ERP in the Williston Basin within the United States and did not differentiate groundwater from surface water. The second method, the supply estimate, focused on groundwater-withdrawal data for North Dakota obtained from water-use permits (North Dakota State Water Commission, 2017). The supply estimate provided pumping rates, locations, and specific aquifers for individual wells that were used in the model simulation. Results of the two methods were consistent, which reduced uncertainty of these estimates.

A combination of groundwater and surface water was used to supply the needs of ERP during 2006-15 (North Dakota State Water Commission, 2017). However, if an extended drought occurred during this period, low streamflows might have resulted in less surface-water availability. The purpose of this scenario was to estimate the effects on the groundwater supply if ERP water demands were totally supplied by groundwater during a drought.

\section{Consumption Estimate}

Total freshwater use for ERP in the Williston Basin in the United States was obtained from Barnhart and others (2018), who tabulated the annual reported freshwater use for hydraulic fracturing (referred to as "treatments") for the study area. Barnhart and others (2018) provided spatially distributed treatment data for a grid spacing of $1 \mathrm{mi}$ but did not determine specific sources of water or differentiate groundwater sources from surface-water sources. Herein, these treatment volumes per grid cell per year were used to determine the consumption estimates. For 2006-15 period, the total consumption estimate was 94,000 acre-feet (acre-ft) for the Williston Basin in the United States, with about 90,000 acre-ft of this in North Dakota and the remainder in Montana. 


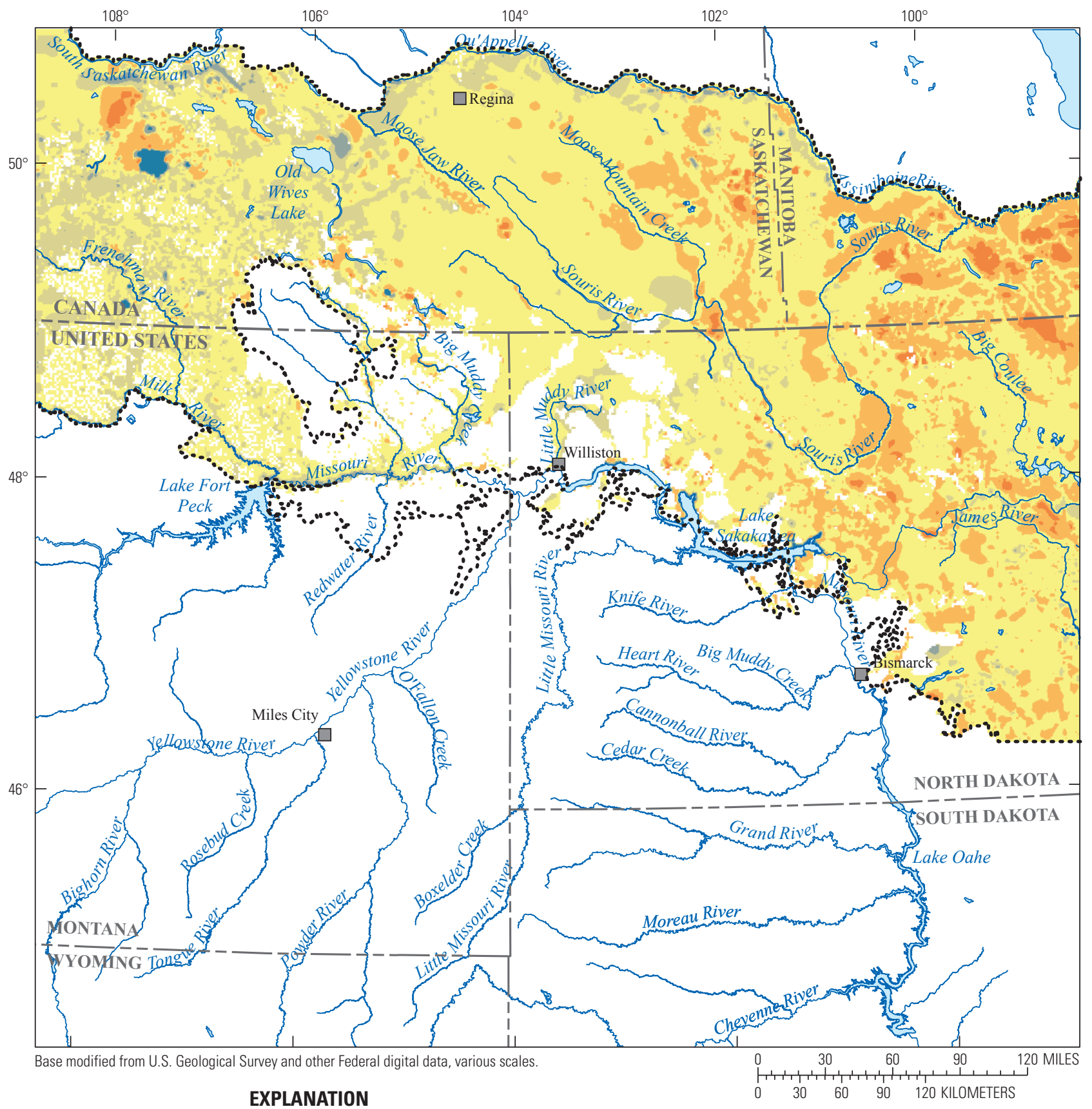

Change in simulated hydraulic head, glacial aquifer system (2005-2015), in feet

$>-231$ to -5
$>-5$ to -1
$>-1$ to 0
$>0$ to 1
$>1$ to 5
$>5$ to 82

-... Extent of the glacial aquifer system. White indicates unsaturated areas.

Williston Basin, United States and Canada. Negative values indicate decline. 


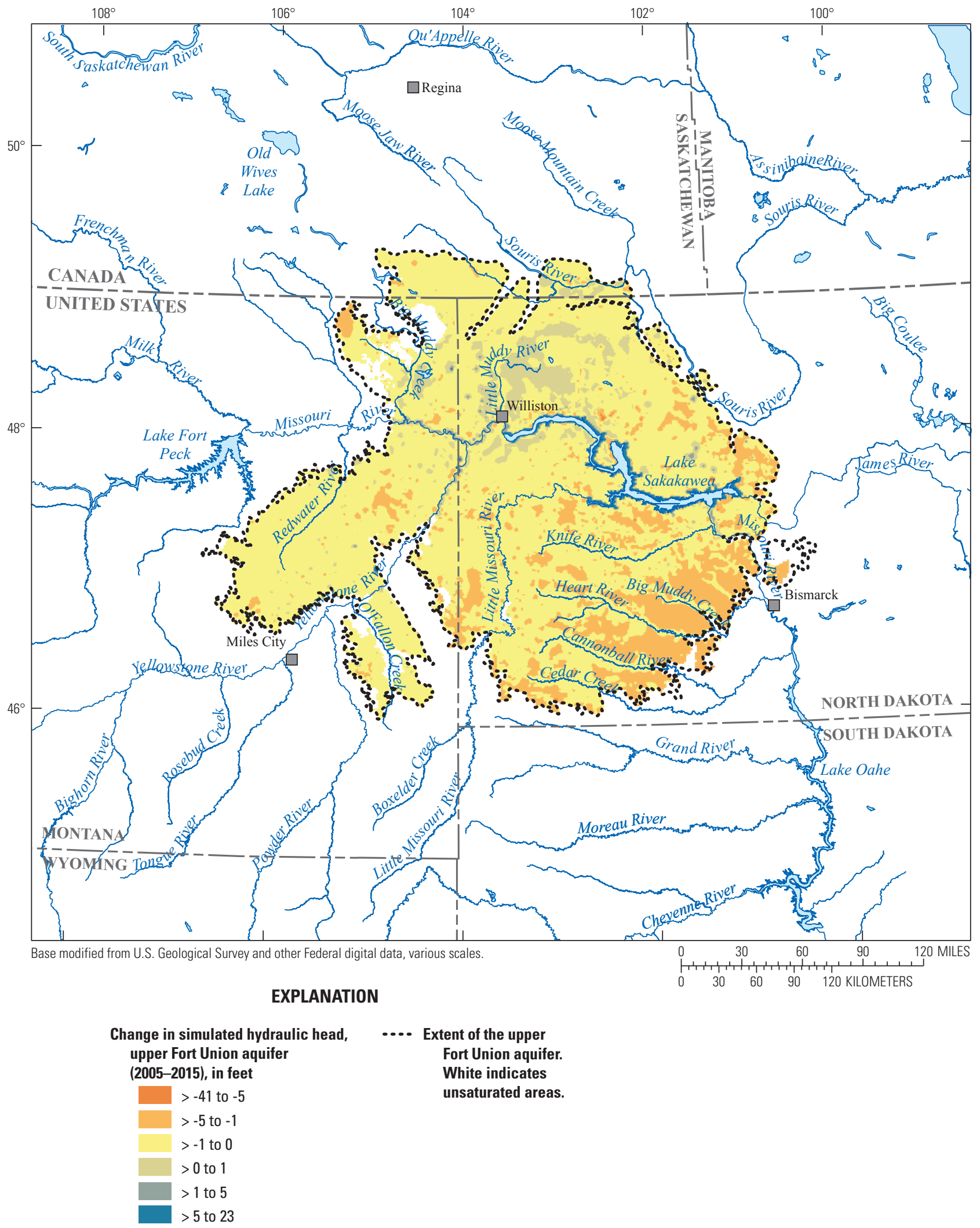

Figure 15. Scenario 2 simulated hydraulic-head change from 2005 to 2015 for the upper Fort Union aquifer, Williston Basin, United States and Canada. Negative values indicate decline. 


\section{Supply Estimate}

The supply estimate was used to assign well locations and pumping rates for ERP applications. This scenario was applied only within the area of North Dakota because the consumption estimate for North Dakota accounted for 96 percent of the total consumption estimate for the Williston Basin in the United States. Additionally, the State of North Dakota provided to the public detailed water-permitting data that could be applied directly to the model. Data for permits to use groundwater and surface water in North Dakota for ERP were obtained from the North Dakota State Water Commission (2017). In addition to the steady groundwater pumping rates applied in scenario 2 , data from these groundwater permits were applied in scenario 3 to account for the additional needs of ERP. Standard permits and temporary permits are two classes of permits that were obtained from the North Dakota State Water Commission. In North Dakota, standard permits generally apply for multiyear periods, whereas temporary permits are issued for 1 year or less. For standard permits, only those issued for use in ERP were used in this scenario. All temporary permits for 2006-2015 granted for industrial purposes were assumed to be used for ERP. Water-use rates reported by each permittee were available for the standard permits and were used in this scenario; for temporary permits, the permitted rates were used because the reported rates were not provided. A small number of permits were either outside of the active model area or open to formations below the Fox Hills aquifer and, therefore, were not included in this scenario.

Although the consumption estimate did not separate groundwater use from surface-water use, a water-budget analysis of the two estimation methods for North Dakota indicated that the supply estimate was consistent with the consumption estimate. The total supply estimate for North Dakota groundwater was 51,000 acre-ft for 2006-15, and the total consumption estimate for North Dakota was 90,000 acre-ft for surface water and groundwater combined, which equates to 39,000 acre-ft of surface-water use. Using these estimates, the ratio of groundwater to surface water is about 1.3. As a comparison, the ratio of groundwater to surface-water usage for the North Dakota standard-permit data for ERP was about 1.4 for the same period. A limitation of this analysis is that groundwater might have been transported across the border of Montana and North Dakota; however, the transport volume was assumed to be cancelled by transport in both directions because of treatments that were needed in Montana.

In many cases, the specific source aquifer was not specified in the groundwater-permit data. For example, in some cases the Fort Union Formation was listed as the source, and this formation was represented by model layers 3,4 , and 5 (Davis and Long, 2018a). In these cases, the simulated well was assigned to model layer 3, 4, or 5, depending on which had the highest hydraulic conductivity to best accommodate the withdrawal rate. In some cases, the source was simply listed as groundwater, in which case the simulated well was assigned to the model layer with the highest hydraulic conductivity for standard permits; for temporary permits, however, the model layer was selected from layers 1-5 because permits for 2006-15 generally were applied to aquifers represented by these model layers.

Although permitted wells with a glacial-aquifer source generally were clustered in areas simulated as saturated, a regional model cannot include a high level of spatial detail and accuracy and, therefore, adjustments to some well locations were made. If a well was at a location that had unsaturated model cells, the location was moved as much as $7 \mathrm{mi}$ to a new location that could better accommodate simulated pumping. About 19 percent of the simulated pumping wells were moved in this way.

\section{Simulation of Scenario 3}

As described in the previous section, the ratio of groundwater to surface-water use for ERP in North Dakota was about 1.4. If, however, surface water was not available, and groundwater was to supply all ERP needs, the total groundwater-use rate of 51,000 acre-ft for 2006-15 would have increased to about 87,400 acre-ft, or 1.71 times higher. Therefore, all ERP water-use data from the North Dakota permits were multiplied by 1.71 for this scenario. Each individual ERP permit site was added as a new pumping well in the simulation. All pumping wells from scenario 2 were assumed to supply non-ERP usage and remained unchanged for scenario 3 .

The difference in simulated hydraulic-head values between scenarios 2 and 3 represents the drawdown that would result from the new wells added to simulate groundwater pumping for ERP needs. The simulated drawdown that resulted from the new wells was less than $25 \mathrm{ft}$ for 2015 (figs. 16, 17, 18). Most of the pumping wells added in scenario 3 were in the glacial aquifer system, upper Fort Union aquifer, and middle Fort Union hydrogeologic unit, and areas of drawdown coincide with these well locations (figs. 16, 17, 18). For many of the added pumping wells, drawdown in the pumped aquifer also resulted in drawdown in the underlying or overlying aquifer. For example, much of the simulated drawdown occurred within areas of the Little Muddy aquifer, which is a sand and gravel aquifer within the glacial aquifer system (fig. 16), and numerous permitted wells added in 
scenario 3 withdraw water from this aquifer. These simulated pumping wells also resulted in drawdown in the upper Fort Union aquifer and to lesser extent in the middle Fort Union hydrogeologic unit (figs. 17, 18). The total area affected by the added pumping wells for scenario 3 is small overall but represents a large part of the Little Muddy aquifer, in addition to other local areas (figs. 16, 17, 18).

A comparison of the scenario 3 groundwater-flow budgets for 2005 and 2015 indicates noteworthy changes. Precipitation recharge decreased by 69 percent, which was the primary forcing that resulted in a 28 percent decrease in the net outflow to surface water. Simulated pumping-well outflow changed from 73.4 in 2005 to $98.3 \mathrm{ft}^{3} / \mathrm{s}$ in 2015 , an increase of $24.9 \mathrm{ft}^{3} / \mathrm{s}$ (18,039 acre-ft/yr), or 34 percent (fig. 19). Although pumping wells do not account for a large part of the budget overall, local effects of these wells are an important consideration for groundwater management. Lowered hydraulic-head values caused flowing-well outflow to decrease by 4 percent. Constant-head inflow and outflow represent groundwater flow across the model-domain boundaries, with greater inflows than outflows.

The stress periods for 2005 and 2015 were similar in having greater total outflows than inflows, the difference of which is shown by the storage change (fig. 19). This indicates that both these years were drier than the previous year (2004 and 2014, respectively). Had the drought simulation followed a wet period, such as the late 1990s, changes would be much larger than shown in figure 19.

\section{Improving Hydrologic Monitoring Networks}

Because of the costs and resources needed to install hydrologic monitoring networks, their design should be well planned and have specific objectives. Numerical groundwaterflow models are used to inform water-management decisions, and a useful application is to design a monitoring network that would provide data that best improves the predictive ability of a model. Because any prediction is inherently uncertain, reducing this uncertainty is critical to improving this ability.

Uncertainty of simulated hydrologic forecasts, or predictive uncertainty, can be reduced by providing additional data to better inform model calibration. If the new data were to come from a new observation well, for example, the degree of uncertainty reduction for a specific forecast of interest depends on the location of this well within the model area. One way to determine the best locations for new observation wells is to apply a method described by Fienen and others (2010) and White and others (2016), referred to in this report as a "data-worth analysis." For example, the model might be used to forecast the effects of a new pumping well on streamflow. If water-level data from a new observation well were used to update the model calibration, this could reduce model uncertainty associated with this forecast of interest, depending on the location of that well. The data-worth value is equal to the forecast uncertainty when a new observation well is included in model calibration divided by the forecast uncertainty without the new well. A data-worth map would show the relative value of additional groundwater-level data at different locations.

As an example, the data-worth analysis was applied to hydrologic forecasts of interest for the Williston Basin simulated by the steady-state model (1981-2005) described by Davis and Long (2018a). Therefore, the analysis applies to equilibrium conditions, but a similar analysis could be applied to scenarios simulating a finite time period. The analysis area includes the Clear Lake and Little Muddy aquifers, which are sand and gravel aquifers within the glacial aquifer system (fig. 20). A simulated pumping well was added to the area representing the Clear Lake aquifer in model layer 2 at a rate of $2.8 \mathrm{ft}^{3} / \mathrm{s}$, and six locations within or near this aquifer were selected as example sites to forecast the effects of the pumping well on hydraulic head (sites H1-H6, fig. 20). All input, output, and executable files for this analysis are in Davis and Long (2018c).

Figure 20 shows the results of the data-worth analysis applied to site H6. The simulated glacial aquifer system, represented by model layers 1 and 2, was unsaturated in upland areas, and therefore, results of the data-worth analysis primarily are restricted to lowland areas, where observation wells could be installed (fig. 20). Simulated groundwater flow is toward the southeast and south in the Clear Lake and Little Muddy aquifers. Northeast of a groundwater divide (fig. 20) that corresponds to a surface-water divide, groundwater flow is toward the north and northeast. The largest area showing high data worth is north of the northern tip of the Clear Lake aquifer, in the northwestern corner of North Dakota (fig. 20), with data-worth values as high as 30 percent. This indicates that it would be a good location for a new observation well and that observations near the upgradient divide, where no observation wells currently are located, would help inform the simulated predictions of hydraulic head at site H6. The area near a groundwater divide might be one of the best locations because this has the highest local hydraulic head that influences groundwater flow downgradient at site $\mathrm{H} 6$. 


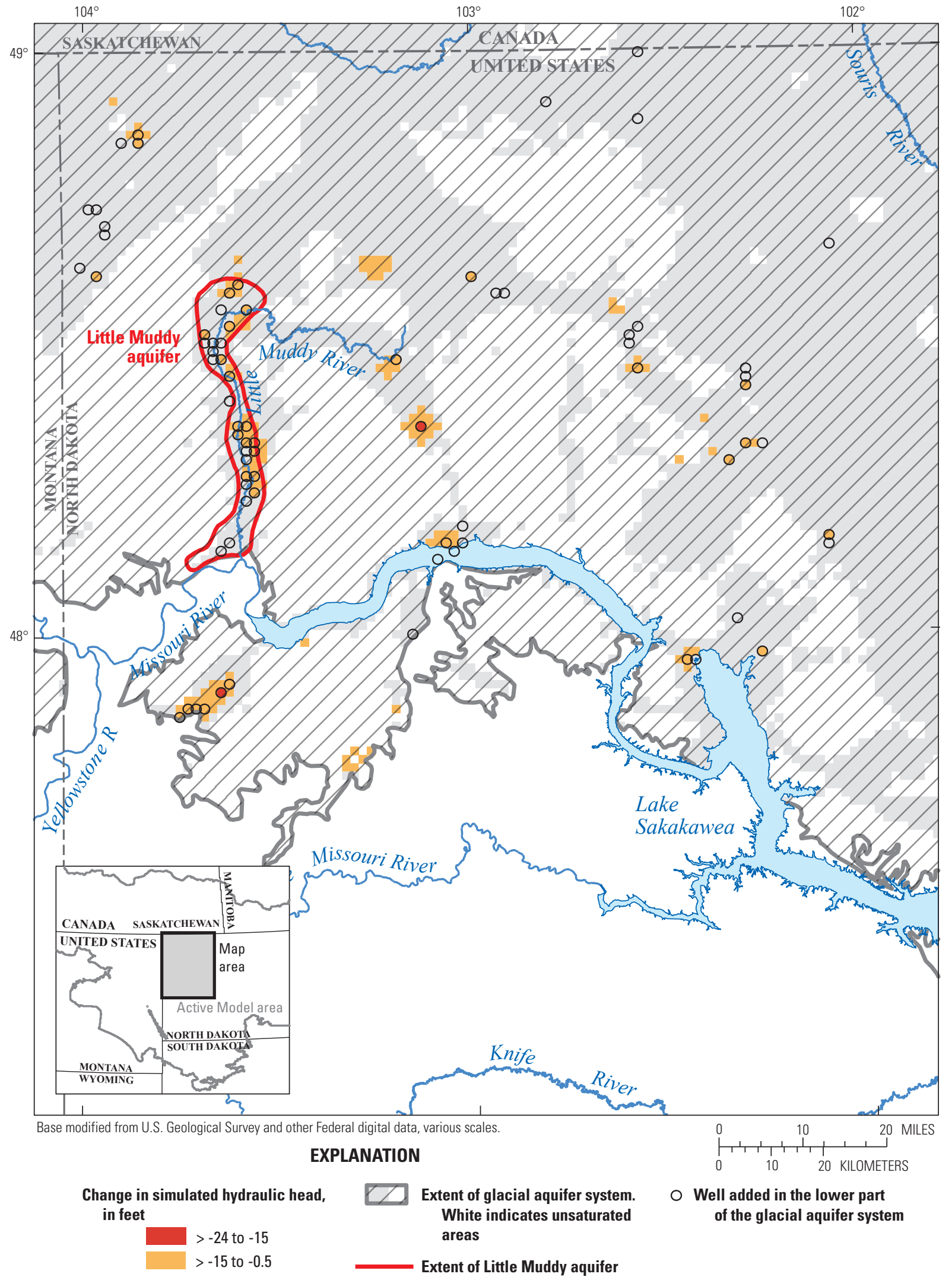

Figure 16. Scenario 3 simulated drawdown of hydraulic head resulting from groundwater withdrawals for energyresource production for 2015 in the glacial aquifer system (model layer 2), Williston Basin, United States and Canada. Negative values indicate decline. 


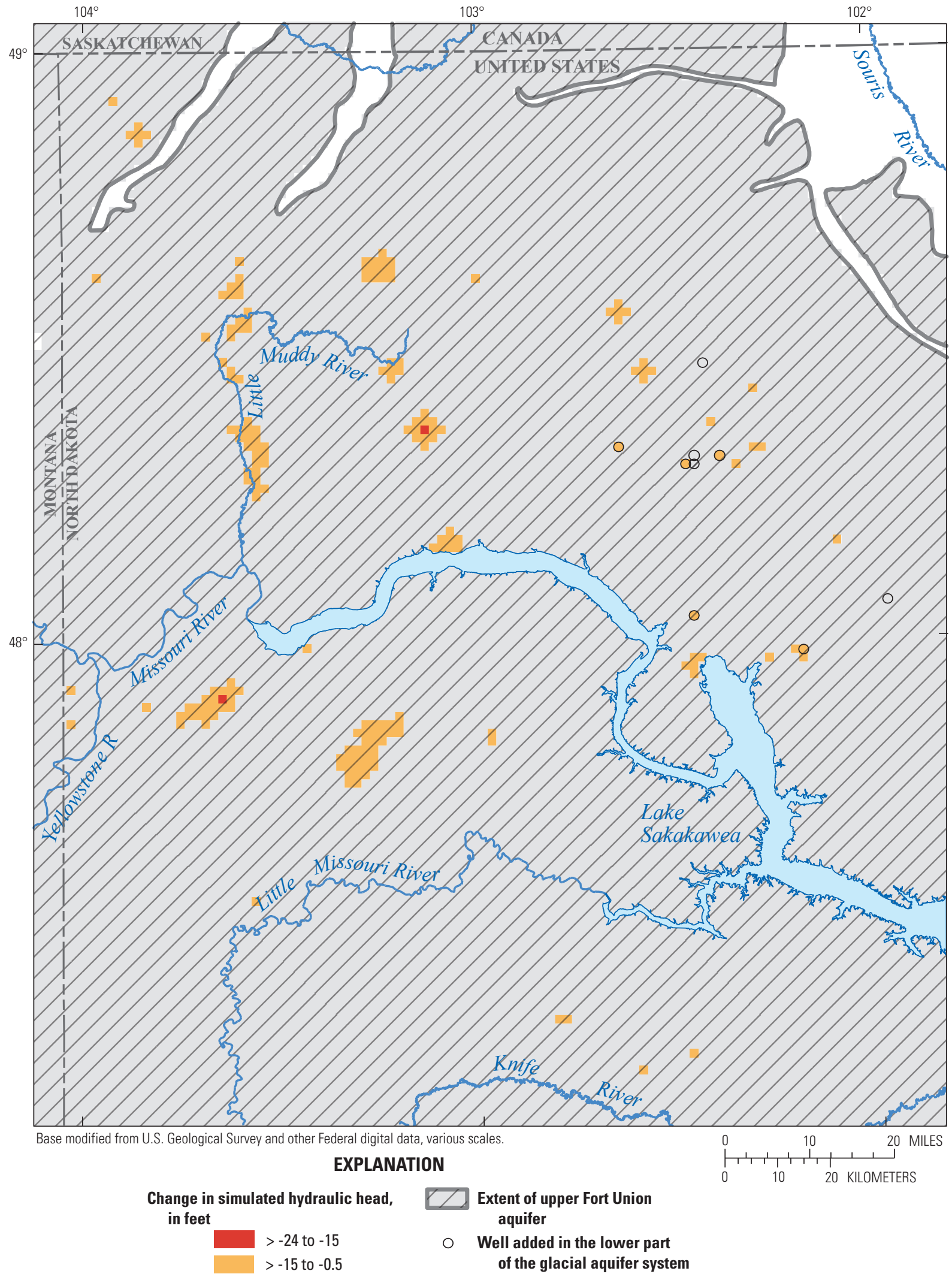

Figure 17. Scenario 3 simulated drawdown of hydraulic head resulting from groundwater withdrawals for energyresource production for 2015 in the upper Fort Union aquifer (model layer 3), Williston Basin, United States and Canada. Negative values indicate decline. 


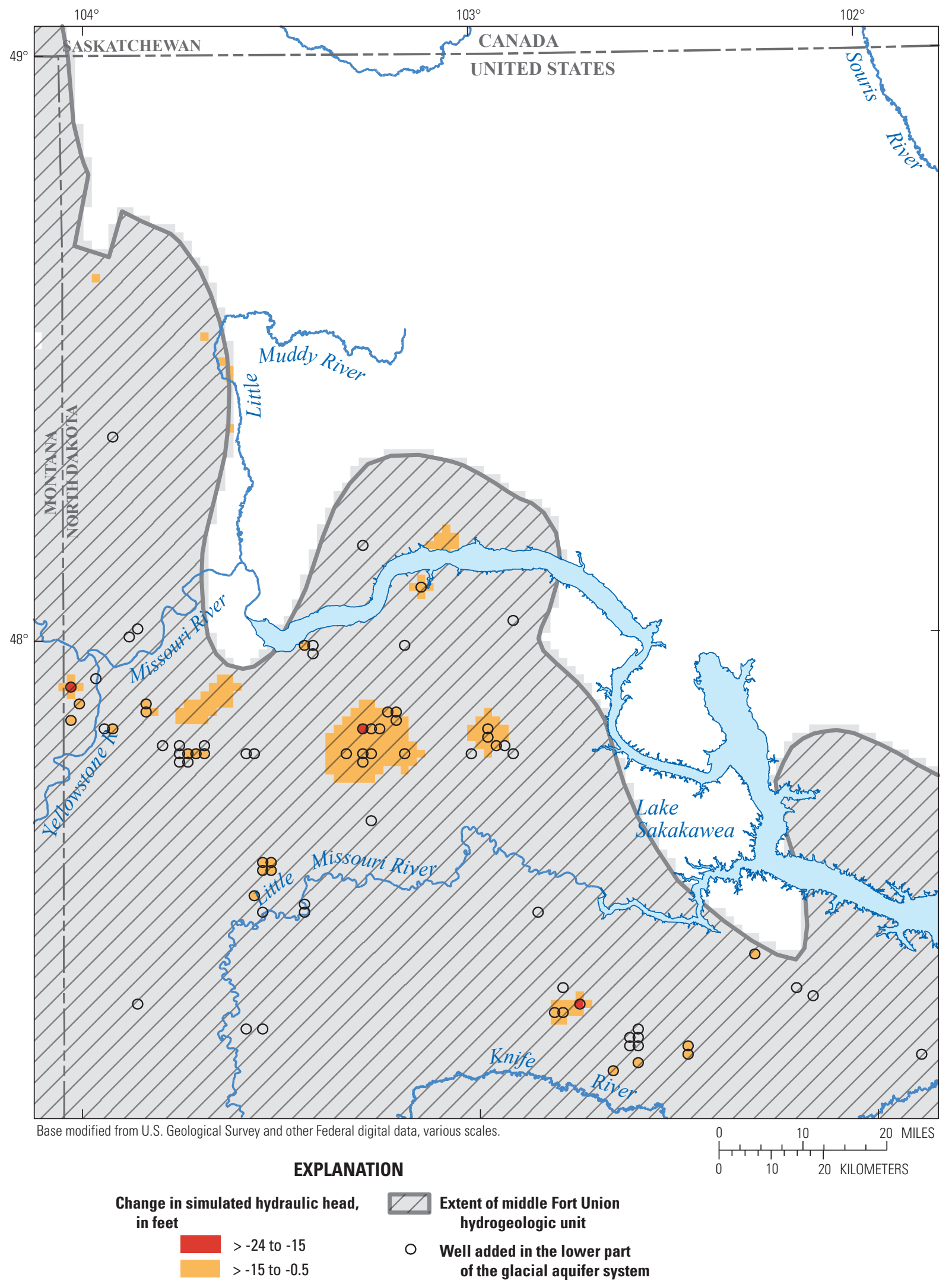

Figure 18. Scenario 3 simulated drawdown of hydraulic head resulting from groundwater withdrawals for energyresource production for 2015 in the middle Fort Union hydrogeologic unit (model layer 4), Williston Basin, United States and Canada. Negative values indicate decline. 


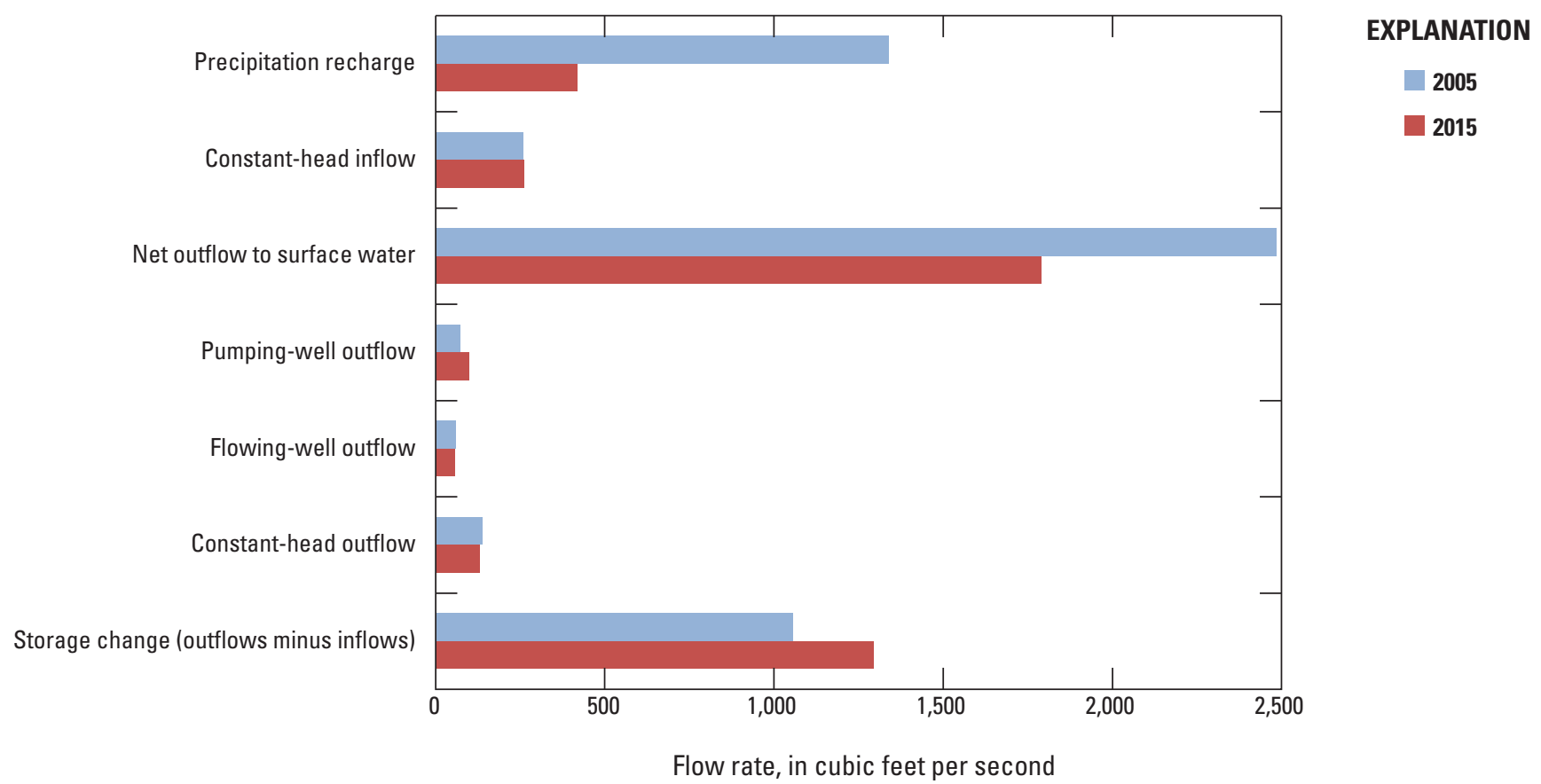

Figure 19. Scenario 3 simulated change in the groundwater-flow budget from 2005 to 2015 for the active model area, Williston Basin, United States and Canada.

The analysis was less clear for sites farther to the southwest of site H6. For site H2, the analysis indicated a slight preference for a new observation well in the far northeastern corner of figure 21, in the areas where data-worth values are in the range of $1-5$ percent. Similar to site H6, this area is near the groundwater divide and has no current observation wells. For site H1, the analysis showed no clear area where an observation well would help inform predictions (fig. 22). Results for sites $\mathrm{H} 3, \mathrm{H} 4$, and $\mathrm{H} 5$ were similar to those of site H1. One factor influencing the low effectiveness of this analysis for sites $\mathrm{H} 1-\mathrm{H} 5$ might be the large areas simulated as unsaturated; this restricts groundwater flow to a narrow area that includes the Clear Lake aquifer. Furthermore, this area already contains observation wells (fig. 22). Site H6, however, is closer to the groundwater divide than the other sites in the Clear Lake aquifer area and is in an area less restricted to the narrow saturated area.
A similar analysis was applied to streamflow predictions of interest. Seven locations for streamflow predictions within and near the Clear Lake aquifer area were selected (sites F1-F7, fig. 23), and the same pumping scenario was applied. Similar to the analysis for sites H1-H5, the analysis for site F3 showed no clear area where an observation well would help inform predictions (fig. 23), and the analyses for the other streamflow-prediction sites all were similar to the analysis for site F3. This probably was a result of the same factors as those related to the hydraulic-head predictions, because sites F1-F7 all are farther southwest of site H6 (figs. 22 and 23). 


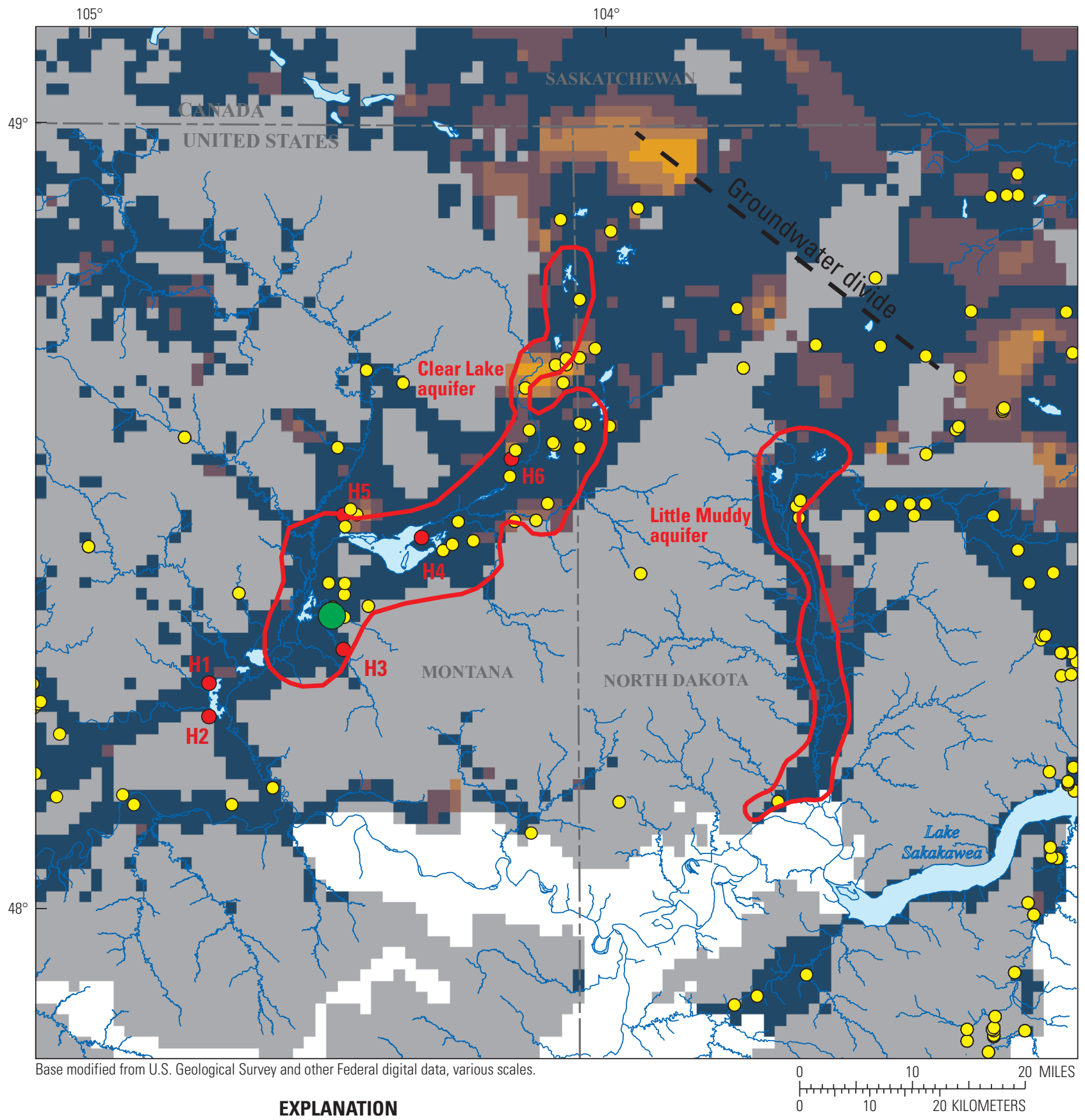

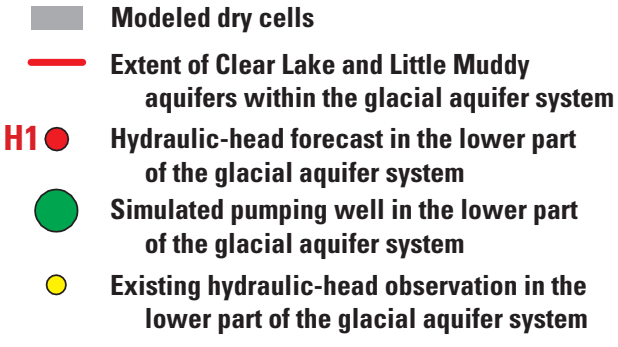

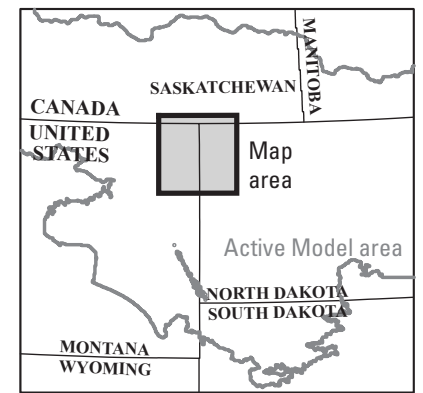

Figure 20. Results of data-worth analysis for hydraulic-head forecasts at site H6, Williston Basin, United States and Canada. The figure shows the relative data-worth values associated with a potential new observation well that, if installed, could reduce simulated uncertainty of a hydraulic-head forecast at site $\mathrm{H} 6$. 
$104^{\circ}$

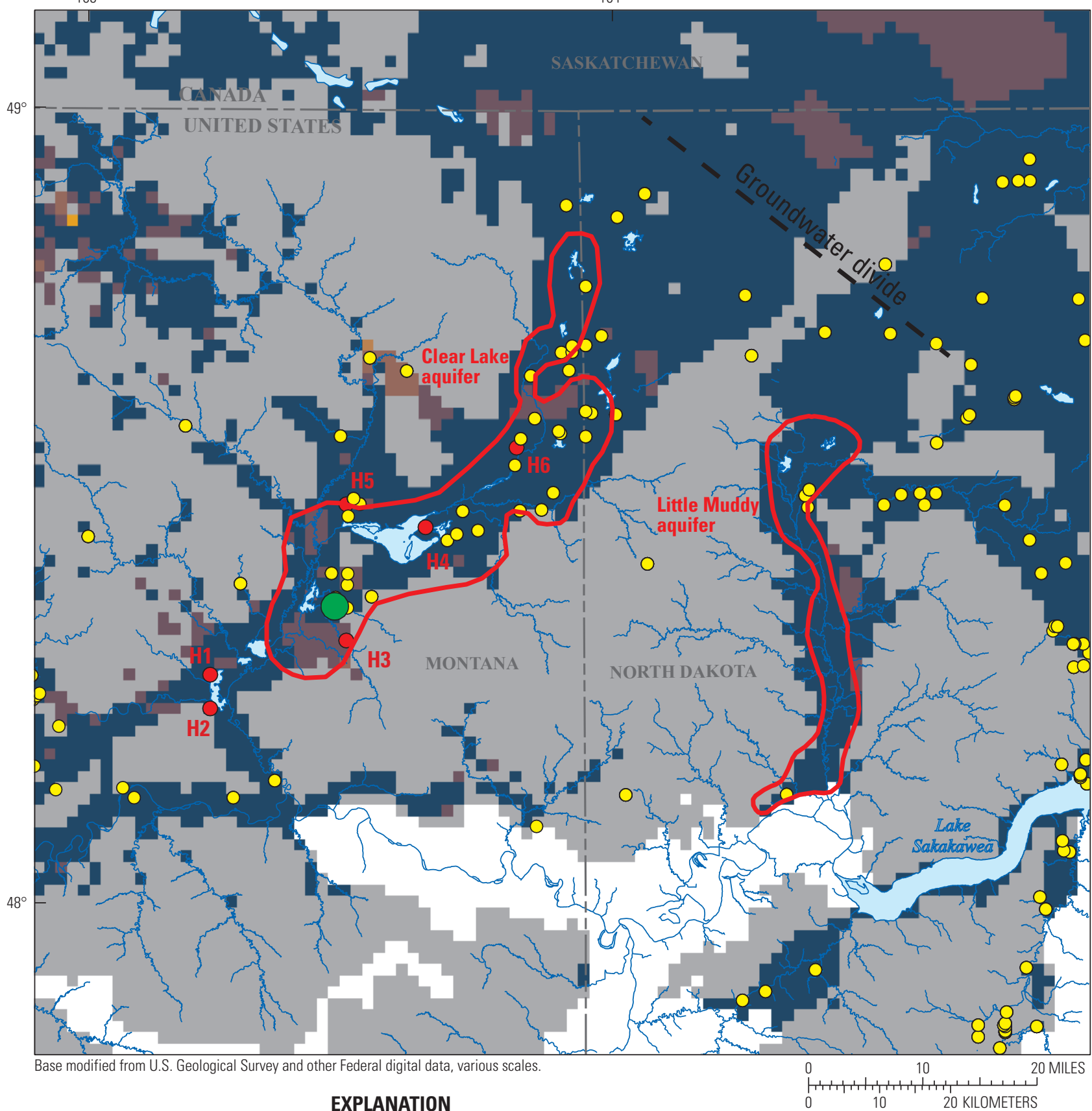

Reduction in uncertainty for hydraulic-head forecast at site $\mathrm{H} 2$, in percent

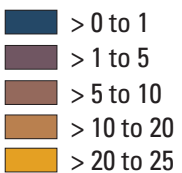

Modeled dry cells

Extent of Clear Lake and Little Muddy aquifers within the glacial aquifer system

H1O Hydraulic-head forecast in the lower part of the glacial aquifer system

Simulated pumping well in the lower part of the glacial aquifer system

$\bigcirc$ Existing hydraulic-head observation in the lower part of the glacial aquifer system

Figure 21. Results of data-worth analysis for hydraulic-head forecasts at site H2, Williston Basin, United States and Canada. The map shows the relative data-worth values associated with a potential new observation well that, if installed, could reduce simulated uncertainty of a hydraulic-head forecast at site $\mathrm{H} 2$. 


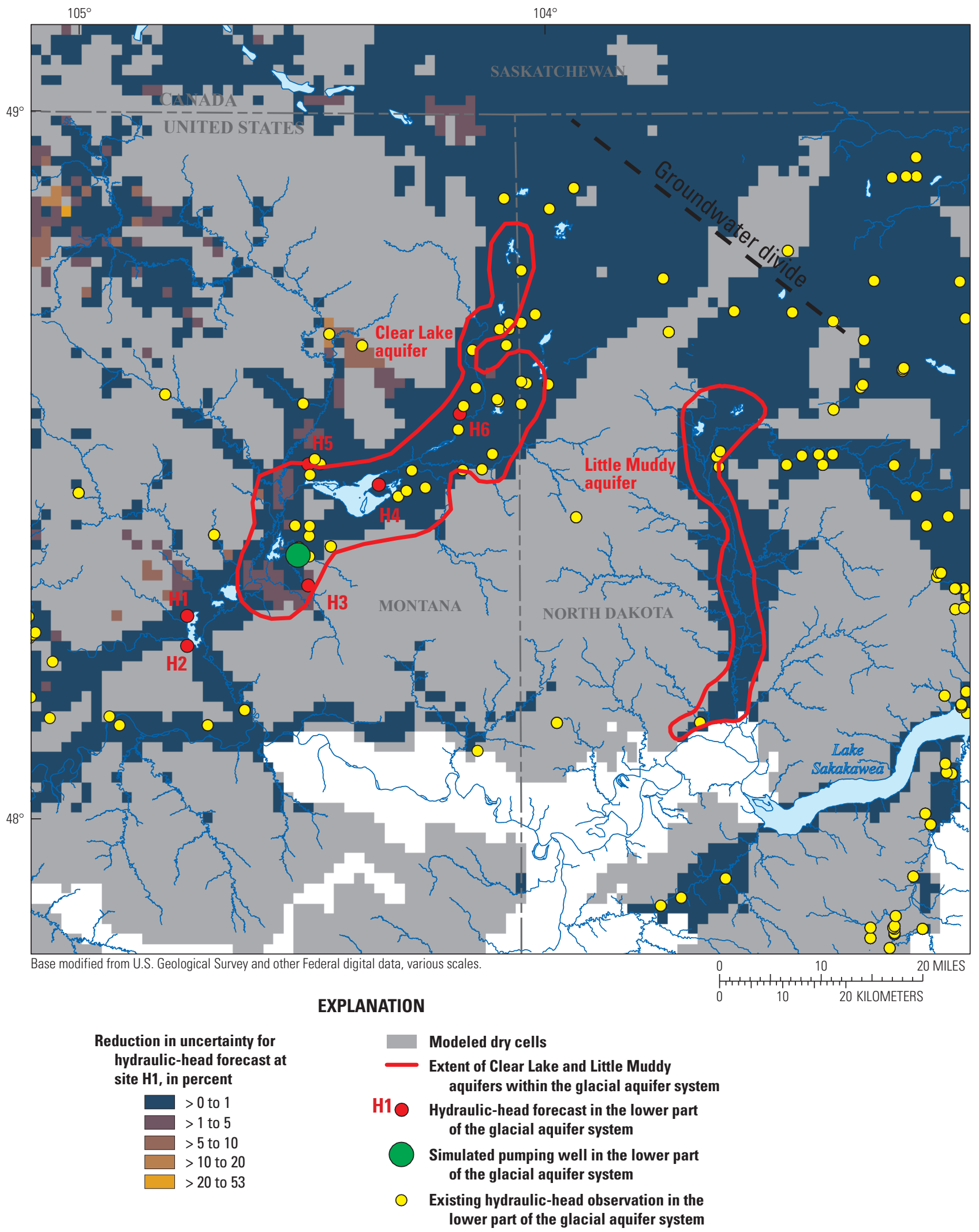

Figure 22. Results of data-worth analysis for hydraulic-head forecasts at site H1, Williston Basin, United States and Canada. The map shows the relative data-worth values associated with a potential new observation well that, if installed, could reduce simulated uncertainty of a hydraulic-head forecast at site $\mathrm{H} 1$. 
$104^{\circ}$

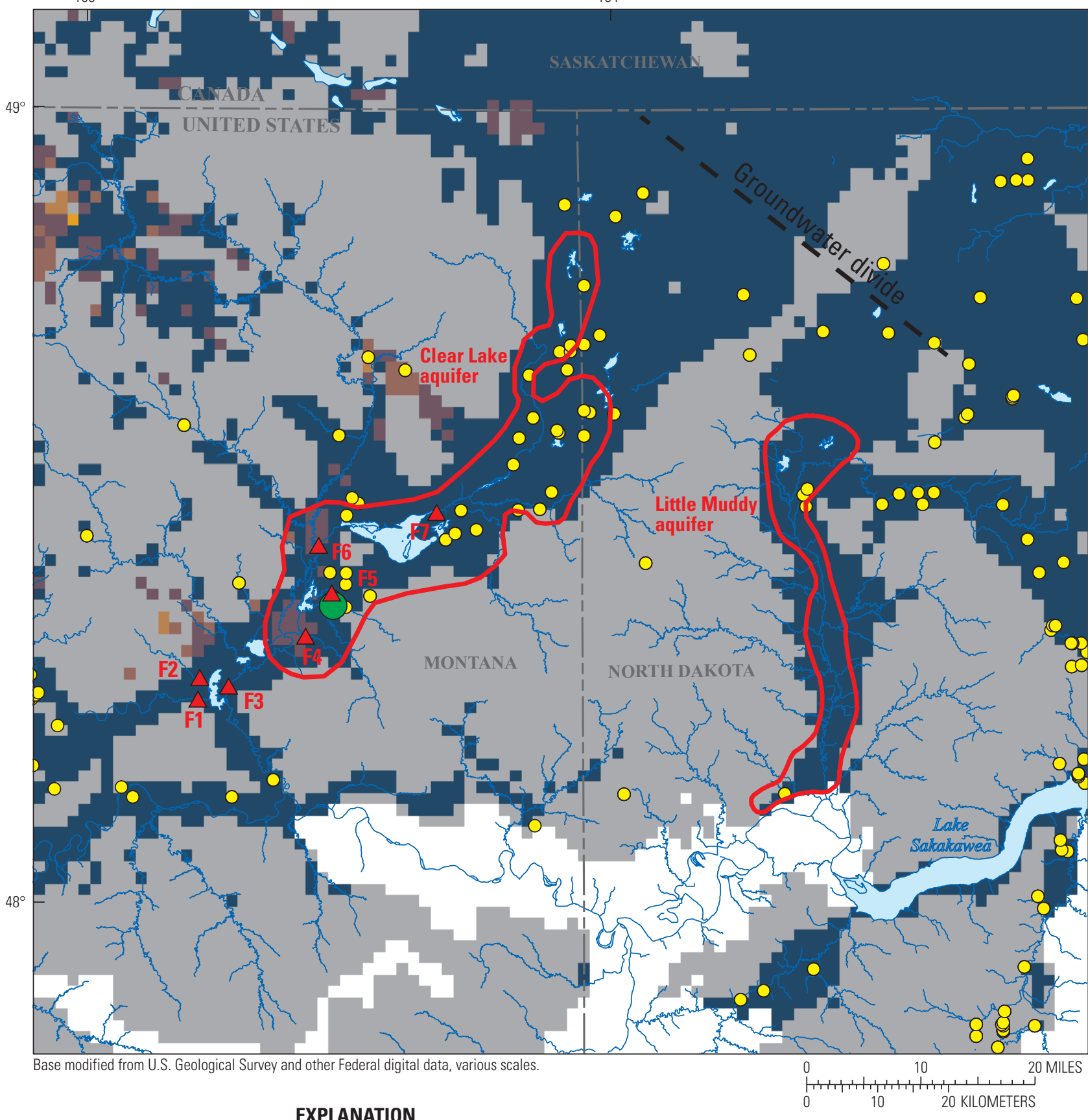

Reduction in uncertainty for streamflow forecast at site $\mathrm{F3}$, in percent

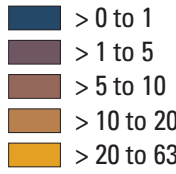

EXPLANATION

Modeled dry cells

Extent of Clear Lake and Little Muddy aquifers within the glacial aquifer system

F1 Streamflow forecast

Simulated pumping well in the lower part of the glacial aquifer system

Existing hydraulic-head observation in the lower part of the glacial aquifer system

Figure 23. Results of data-worth analysis for streamflow forecasts at site F3, Williston Basin, United States and Canada. The map shows the relative data-worth values associated with a potential new observation well that, if installed, could reduce simulated uncertainty of a streamflow forecast at site F3. 


\section{Numerical Groundwater-Flow Model Uses, Limitations, and Challenges}

The numerical groundwater-flow model described herein is useful for groundwater resource management and planning (Davis and Long, 2018a). Groundwater resources are affected by climate and the use of groundwater for human activities, for which numerous scenarios are possible during the coming years and decades. Scenario examples show how this model can be used to assess and plan for hydrologic stressors; however, numerous additional scenarios could be simulated. The digital files associated with this model and scenario simulations are available to government entities and the public for simulating other scenarios of interest (Davis and Long, 2018b, 2018c). The model also may be useful for the planning of data-collection networks, as described in section, "Improving Hydrologic Monitoring Networks."

All models are simplified approximations of the real world, but different models are designed and applied to different scales of space and time. Because the model described herein is regional, its strength is in regional applications and assessments. The horizontal dimension of each model cell is $1 \mathrm{mi}$ on each side and, therefore, the model cannot simulate groundwater gradients and flows at less than this scale. However, the effects of a single pumping well can be simulated in a meaningful way, especially if the well's zone of influence extends into multiple model cells. A similar scale of effective simulation applies to the interaction of groundwater and surface water. The time scale of this model is separated into annual and 5-year periods within which hydrologic stresses are constant, meaning seasonal, monthly, or daily changes cannot be simulated. The strength of this model is in the assessment of interannual or interdecadal changes, such as a 5-year drought or long-term groundwater decline resulting from groundwater extraction. Additional details on model limitations were described in Davis and Long (2018a), such as limited data availability related to flowing artesian wells.

A considerable challenge in assessing groundwater availability for the Nation is that this resource primarily is of a regional nature. A map of the principal aquifers of the United States illustrates the regional extent of these aquifers and aquifer systems (U.S. Geological Survey, 2018). Numerical groundwater models provide the best available scientific tool for assessing groundwater availability under potential future scenarios and hydrologic stressors. These models represent regional flow systems that are stressed by extensive human activity and climatic fluctuations. Although processes occurring at fine scales of time and space contribute to the processes occurring at long-term and regional scales, the models must be simplified and discretized into coarse scales because of limitations of computational power, as well as limitations imposed on the scope and time frame of the overall investigation. Therefore, regional groundwater availability assessments favor the big picture over fine-scale processes, important as they may be. Nonetheless, these bigpicture assessments are critical to understanding and assessing groundwater availability for the Nation, now and in the future.

\section{References Cited}

Aber, J.S., Croot, D.G., and Fenton, M.M., 1989, Nature of glaciotectonism, in Aber, J.S., Croot, D.G., and Fenton, M.M., eds., Glaciotectonic landforms and structures: Berlin, Germany, Springer Nature, p. 1-12, doi:10.1007/978-94015-6841-8_1.

Anderson, M.T., and Woosley, L.H., Jr., 2005, Water availability for the Western United States-Key scientific challenges: U.S. Geological Survey Circular 1261, 85 p., https://pubs.usgs.gov/circ/2005/circ1261/.

Anna, L.O., 1986, Geologic framework of the ground-water system in Jurassic and Cretaceous rocks in the Northern Great Plains, in parts of Montana, North Dakota, South Dakota, and Wyoming: U.S. Geological Survey Professional Paper 1402-B, 36 p., https://doi.org/10.3133/pp1402B.

Anna, L.O., Pollastro, Richard, and Gaswirth, S.B., 2011, Williston Basin Province-Stratigraphic and structural framework to a geologic assessment of undiscovered oil and gas resources, in U.S. Geological Survey Williston Basin Province Assessment Team, comp., Assessment of undiscovered oil and gas resources of the Williston Basin Province of North Dakota, Montana, and South Dakota, 2010: U.S. Geological Survey Digital Data Series 69-W, chap. 2, 21 p., 1 CD-ROM, https://doi.org/10.3133/ds69W.

Aurand, K.R., 2013, Groundwater recharge estimates for the lower Tertiary and Upper Cretaceous aquifers in the Williston and Powder River structural basins: Rapid City, South Dakota, South Dakota School of Mines and Technology, M.S. thesis, 107 p.

Bates, R.L., and Jackson, J.A., 1984, Dictionary of geological terms (3rd ed.): New York, Doubleday, 571 p.

Barlow, P.M., and Leake, S.A., 2012, Streamflow depletion by wells - Understanding and managing the effects of groundwater pumping on streamflow: U.S. Geological Survey Circular 1376, 84 p., https://doi.org/10.3133/ cir1376.

Barnhart, T.B., Long, A.J., Haines, S.S., and Varela, B., 2018, Water use for hydraulic fracturing treatments in the Williston Basin, United States, 2000-2015: U.S. Geological Survey data release, https://doi.org/10.5066/F78P5ZDV. 
Bartolino, J.R., and Cole, J.C., 2002, Ground-water resources of the Middle Rio Grande Basin, New Mexico: U.S. Geological Survey Circular 1222, 132 p.

Bednar, J.M., 2013, Interaction of groundwater and surface water in the Williston and Powder River structural basins: Rapid City, South Dakota, South Dakota School of Mines and Technology, M.S. Thesis, 120 p.

Benn, D.I., and Evans, D.J.A., 1998, Glaciers and glaciation: New York, Oxford University Press, Inc., 734 p.

Bluemle, J.P., 1983, Geologic and topographic bedrock map of North Dakota: North Dakota Geological Survey, Miscellaneous Map 25, 1 sheet, scale 1:670,000.

Bluemle, J.P., 1998, The coalbed methane potential of North Dakota lignites: North Dakota Geological Survey Open-File Report 98-1, 38 p.

Campbell, B.G., and Coes, A.L., eds., 2010, Groundwater availability in the Atlantic Coastal Plain of North and South Carolina: U.S. Geological Survey Professional Paper 1773, 241 p., 7 pls., https://doi.org/10.3133/pp1773.

Clark, B.R., Hart, R.M., and Gurdak, J.J., 2011, Groundwater availability of the Mississippi embayment: U.S. Geological Survey Professional Paper 1785, 62 p., https://doi. org/10.3133/pp1785.

Cohen, K.M., Finney, S.C., Gibbard, P.L., and Fan, J., 2017, International chronostratigraphic chart: International Commission on Stratigraphy, v. 2017-02. [Also available at https://www.stratigraphy.org/ICSchart/ ChronostratChart2017-02.pdf.]

Cummings, D.I., Russell, H.A.J., and Sharpe, D.R., 2012, Buried-valley aquifers in the Canadian Prairies-Geology, hydrogeology, and origin: Canadian Journal of Earth Sciences, v. 49, p. 987-1004.

Dolton, G.L., Fox, J.E., and Clayton, J.L., 1990, Petroleum geology of the Powder River Basin, Wyoming and Montana: U.S. Geological Survey Open-File Report 88-450-P, 64 p., https://doi.org/10.3133/ofr88450P.

Davis, K.W., and Long, A.J., 2018a, Construction and calibration of a groundwater-flow model to assess groundwater availability in the uppermost principal aquifer systems of the Williston Basin, United States and Canada: U.S. Geological Survey Scientific Investigations Report 2017-5158, 70 p., https://doi.org/10.3133/sir20175158.

Davis, K.W., and Long, A.J., 2018b, MODFLOW-NWT model used to assess groundwater availability in the uppermost principal aquifer systems of the Williston structural basin, United States and Canada: U.S. Geological Survey data release, https://doi.org/10.5066/F75B01CZ.
Davis, K.W., and Long, A.J., 2018c, MODFLOW-NWT model of predictive simulations of groundwater response to selected scenarios in the Williston Basin, United States and Canada: U.S. Geological Survey data release, https://doi. org/10.5066/P9FACTT3.

Downey, J.S., 1986, Geohydrology of bedrock aquifers in the Northern Great Plains in parts of Montana, North Dakota, South Dakota, and Wyoming: U.S. Geological Survey Professional Paper 1402-E, 87 p., https://doi.org/10.3133/ pp1402E.

Downey, J.S., and Dinwiddie, G.A., 1988, The regional aquifer system underlying the Northern Great Plains in parts of Montana, North Dakota, South Dakota, and WyomingSummary: U.S. Geological Survey Professional Paper 1402-A, 64 p., 3 pls., https://doi.org/10.3133/pp1402A.

Faunt, C.C., Hanson, R.T., Belitz, K., Schmid, W., Predmore, S.P., Rewis, D.L., and McPherson, K., 2009, Groundwater availability of the Central Valley aquifer, California: U.S. Geological Survey Professional Paper 1766, 225 p., https://doi.org/10.3133/pp1766.

Fienen, M.N., Doherty, J.E., Hunt, R.J., and Reeves, H.W., 2010, Using prediction uncertainty analysis to design hydrologic monitoring networks-Example applications from the Great Lakes water availability pilot project: U.S. Geological Survey Scientific Investigations Report 2010-5159, 44 p., https://doi.org/10.3133/sir20105159.

Fischer, K., 2013, Groundwater flow model inversion to assess water availability in the Fox Hills-Hell Creek aquifer: North Dakota State Water Commission, North Dakota Water Resource Investigation No. 54, 325 p. [Also available at http://www.swc.nd.gov/info_edu/reports_and_publications/ water_resource_investigations.html.]

Flores, R.M., 1992, Sedimentology of the Upper Cretaceous and Paleocene coal-bearing regressive sequences, Williston Basin, Montana, in Sholes, M.A., ed., Coal geology of Montana: Montana Bureau of Mines and Geology Special Publication 102, p. 1-21.

Flores, R.M., and Bader, L.R., 1999, Fort Union coal in the Powder River Basin, Wyoming and Montana-A synthesis, in U.S. Geological Survey, comp., 1999 Resource assessment of selected Tertiary coal beds and zones in the Northern Rocky Mountains and Great Plains Region: U.S. Geological Professional Paper 1625-A, chap. PS, WF1-WF64, https://doi.org/10.3133/pp1625A. 
Gaswirth, S.B., Marra, K.R., Cook, T.A., Charpentier, R.R., Gautier, D.L., Higley, D.K., Klett, T.R., Lewan, M.D., Lillis, P.G., Schenk, C.J., Tennyson, M.E., and Whidden, K.J., 2013, Assessment of undiscovered oil resources in the Bakken and Three Forks Formations, Williston Basin Province, Montana, North Dakota, and South Dakota, 2013: U.S. Geological Survey Fact Sheet 2013-3013, 4 p., https://doi.org/10.3133/fs20133013.

Haines, S.S., Varela, B.A., Hawkins, S.J., Gianoutsos, N.J., Thamke, J.N., Engle, M.A., Tennyson, M.E., Schenk, C.J., Gaswirth, S.B., Marra, K.R., Kinney, S.A., Mercier, T.J., and Martinez, C.D., 2017, Assessment of water and proppant quantities associated with petroleum production from the Bakken and Three Forks Formations, Williston Basin Province, Montana and North Dakota, 2016: U.S. Geological Survey Fact Sheet 2017-3044, 4 p., https://doi. org/10.3133/fs20173044.

Hamke, J.R., Marchant, L.C., and Cupps, C.Q., 1966, Oilfields in the Williston Basin in Montana, North Dakota, and South Dakota: U.S. Bureau of Mines Bulletin 629, 487 p.

Harbaugh, A.W., 2005, MODFLOW-2005-The U.S. Geological Survey modular ground-water model-The ground-water flow process: U.S. Geological Survey Techniques and Methods 6-A16, variously paged, https:// doi.org/10.3133/tm6A16.

Hart, J.K., and Boulton, G.S., 1991, The inter-relation of glaciotectonic and glaciodepositional processes within the glacial environment: Quaternary Science Reviews, v. 10, p. 335-350.

Healy, R.W., 2010, Estimating groundwater recharge: Cambridge, United Kingdom, Cambridge University Press, $245 \mathrm{p}$.

Healy, R.W., and Cook, P.G., 2002, Using groundwater levels to estimate recharge: Hydrogeology Journal, v. 10, no. 1, p. 91-109, https://dx.doi.org/10.1007/s10040-001-0178-0.

Heilweil, V.M., and Brooks, L.E., eds., 2011, Conceptual model of the Great Basin carbonate and alluvial aquifer system: U.S. Geological Survey Scientific Investigations Report 2010-5193, $191 \mathrm{p}$.

Honeyman, R.P., 2007a, Pressure head fluctuations of the Fox Hills-Hell Creek aquifer in Billings, Golden Valley, and Slope Counties, North Dakota: North Dakota State Water Commission, Water Resources Investigation No. 42, 115 p. [Also available at http://www.swc.nd.gov/info_edu/reports_ and_publications/water_resource_investigations.html.]
Honeyman, R.P., 2007b, Pressure head fluctuations of the Fox Hills-Hell Creek aquifer in McKenzie County, North Dakota: North Dakota State Water Commission, Water Resources Investigation No. 43, 130 p. [Also available at https://www.swc.nd.gov/info_edu/reports_and_publications/ water_resource_investigations.html.]

Honeyman, R.P., 2007c, Pressure head fluctuations of the Fox Hills-Hell Creek aquifer in the Knife River Basin, North Dakota: North Dakota State Water Commission, Water Resources Investigation No. 44, 86 p. [Also available at https://www.swc.nd.gov/info_edu/reports_and_publications/ water_resource_investigations.html.]

Kehew, A.E., and Boettger, W.M., 1986, Depositional environments of buried-valley aquifers in North Dakota: Ground Water, v. 24, no. 6, p. 728-734.

Long, A.J., Aurand, K.R., Bednar, J.M., Davis, K.W., Mckaskey, J.D.R.G., and Thamke, J.N., 2014, Conceptual model of the uppermost principal aquifer systems in the Williston and Powder River structural basins, United States and Canada: U.S. Geological Survey Scientific Investigations Report 2014-5055, 41 p., https://doi. org/10.3133/sir20145055.

Love, J.D., and Christiansen, A.C., 1985, Geologic map of Wyoming: U.S. Geological Survey unnumbered series, 3 sheets, scale 1:500,000, https://pubs.er.usgs.gov/ publication/70046739.

Macdonald, R., and Slimmon, W.L., comps., 1999, Geological map of Saskatchewan: Saskatchewan Industry and Resources, Saskatchewan Geological Survey, 1 sheet, scale 1:1,000,000.

Martin, J.E., Sawyer, J.F., Fahrenbach, M.D., Tomhave, D.W., and Schulz, L.D., 2004, Geologic map of South Dakota: South Dakota Geological Survey, General Map Series 10, scale 1:500,000.

Masterson, J.P., Pope, J.P., Fienen, M.N., Monti, J., Jr., Nardi, M.R., and Finkelstein, J.S., 2016, Assessment of groundwater availability in the Northern Atlantic Coastal Plain aquifer system from Long Island, New York, to North Carolina: U.S. Geological Survey Professional Paper 1829, 76 p., https://doi.org/10.3133/pp1829.

Maupin, M.A., and Barber, N.L., 2005, Estimated withdrawals from principal aquifers in the United States, 2000: U.S. Geological Survey Circular 1279, 46 p., https://doi. org/10.3133/cir1279.

Maurer, E.P., Wood, A.W., Adam, J.C., Lettenmaier, D.P., and Nijssen, B., 2002, A long-term hydrologically-based data set of land surface fluxes and states for the conterminous United States: Journal of Climate, v. 15, no. 22, p. 3237-3251. 
Montana Department of Natural Resources and Conservation, 2014, Montana State water plan-A watershed approach to the 2015 Montana State Water Plan: Montana Department of Natural Resources and Conservation, $81 \mathrm{p}$.

Multi-Resolution Land Characteristics Consortium, 2011, National land cover database - Conterminous United States NLCD 2006 land cover: U.S. Geological Survey MultiResolution Land Characteristics Consortium database, 30-m data, https://www.mrlc.gov/nlcd2006.php.

Murphy, E.C., Nordeng, S.H., Juenker, B.J., and Hoganson, J.W., 2009, North Dakota stratigraphic column: North Dakota Geological Survey Miscellaneous Series 91, $1 \mathrm{p}$.

National Oceanic and Atmospheric Administration, 2018a, Climate data online-Dataset discovery: National Oceanic and Atmospheric Administration, Climate Data Online, https://www.ncdc.noaa.gov/cdo-web/datasets\#ANNUAL.

National Oceanic and Atmospheric Administration, 2018b, GHCN-monthly version 2: National Oceanic and Atmospheric Administration, Global Historical Climatology Network, https://www.ncdc.noaa.gov/ghcnm/v2.php.

Nicolas, M.P.B., Matile, G.L.D., Keller, G.R., and Bamburak, J.D., 2010, Phanerozoic geology of southern Manitoba: Manitoba Geological Survey Stratigraphic Map Series SM2010-1, 1 sheet, scale 1:600,000.

North Dakota State Water Commission, 2015, 2015 North Dakota State Water Management Plan: North Dakota State Water Commission, $119 \mathrm{p}$.

North Dakota State Water Commission, 2017, State Water Commission and Office of the State Engineer: North Dakota State Water Commission, https://www.swc.nd.gov/info_edu/ map_data_resources/.

Northwest Alliance for Computational Science and Engineering, 2018, PRISM climate data: Corvallis, Oregon State University, Northwest Alliance for Computational Science and Engineering, http://www.prism.oregonstate. edu/.

Paschke, S.S., ed., 2011, Groundwater availability of the Denver Basin aquifer system, Colorado: U.S. Geological Survey Professional Paper, 274 p., https://pubs.usgs.gov/ $\mathrm{pp} / 1770 /$.

Pitman, J.K., Price, L.C., and LeFever, J.A., 2001, Diagenesis and fracture development in the Bakken Formation, Williston Basin-Implications for reservoir quality in the middle member: U.S. Geological Survey Professional Paper 1653, 19 p., https://doi.org/10.3133/pp1653.
Pollastro, R.M., Roberts, L.N.R., and Cook, T.A., 2013, Geologic assessment of technically recoverable oil in the Devonian and Mississippian Bakken Formation, in U.S. Geological Survey Williston Basin Province Assessment Team, compilers, Assessment of undiscovered oil and gas resources of the Williston Basin Province of North Dakota, Montana, and South Dakota, 2010: U.S. Geological Survey Digital Data Series DDS-69-W, chap. 5, of U.S. Geological Survey Williston Basin Province (ver. 1.1, November 2013), https://doi.org/10.3133/ds69W.

Pugin, A.J.-M., Oldenborger, G.A., Cummings, D.I., Russell, H.A.J., and Sharpe, D.R., 2014, Architecture of buried valleys in glaciated Canadian Prairie regions based on high resolution geophysical data: Quaternary Science Reviews, v. 86, p. 13-23.

Reeves, H.W., 2010, Water availability and use pilot-A multiscale assessment in the U.S. Great Lakes Basin: U.S. Geological Survey Professional Paper 1778, 105 p., https:// doi.org/10.3133/pp1778.

Reeves, H.W., Bayless, E.R., Dudley, R.W., Feinstein, D.T., Fienen, M.N., Hoard, C.J., Hodgkins, G.A., Qi, S.L., Roth, J.L., and Trost, J.J., 2017, Generalized hydrogeologic framework and groundwater budget for a groundwater availability study for the glacial aquifer system of the United States: U.S. Geological Survey Scientific Investigations Report 2017-5015, 49 p., https://doi. org/10.3133/sir20175015.

Reilly, T.E., Dennehy, K.F., Alley, W.M., and Cunningham, W.L., 2008, Ground-water availability in the United States: U.S. Geological Survey Circular 1323, 70 p., https://doi.org/10.3133/cir1323.

Sandberg, C.A., 1962, Geology of the Williston Basin, North Dakota, Montana, and South Dakota, with reference to subsurface disposal of radioactive wastes: U.S. Geological Survey Open-File Report 62-115, 148 p., https://doi. org/10.3133/ofr62115.

Scanlon, B.R., Reedy, R.C., Male, F., and Hove, M., 2016, Managing the increasing water footprint of hydraulic fracturing in the Bakken Play, United States: Environmental Science and Technology, v. 50, no. 18, p. 10273-10281.

Schuh, W.M., 2010, Water appropriation requirements, current water use, and water availability for energy industries in North Dakota - A 2010 summary: North Dakota State Water Commission Water Resources Investigation No. 49, 415 p. [Also available at http://www.swc.nd.gov/info_edu/reports and_publications/water_resource_investigations.html.]

Smith, L.N., LaFave, J.I., Patton, T.W., Rose, J.C., and McKenna, D.P., 2000, Groundwater resources of the Lower Yellowstone River area-Dawson, Fallon, Prairie, Richland, and Wibaux Counties, Montana: Montana Bureau of Mines and Geology Groundwater Assessment Atlas 1, variously paged. 
Statistics Canada, 2001, Population counts, land area and population density, for Canada, Provinces and Territories, 2001 census: Statistics Canada. [Available at https:// www12.statcan.ca/english/census01/products/standard/ popdwell/Table-PR.cfm?T=2\&S=1\&O=A.]

Thamke, J.N., LeCain, G.D., Ryter, D.W., Sando, Roy, and Long, A.J., 2014, Hydrogeologic framework of the upper principal aquifer systems in the Williston and Powder River structural basins, United States and Canada: U.S. Geological Survey Scientific Investigations Report 20145047, 38 p., https://doi.org/10.3133/sir20145047.

Thamke, J.N., Long, A.J., and Davis, K.W., 2018, Williston Basin groundwater availability, United States and Canada: U.S. Geological Survey Fact Sheet 2018-3046, 4 p., https:// doi.org/10.3133/fs20183046.

Thornton, P.E., Running, S.W., and White, M.A., 1997, Generating surfaces of daily meteorology variables over large regions of complex terrain: Amsterdam, Netherlands, Journal of Hydrology, v. 190, p. 214-251, https://dx.doi. org/10.1016/S0022-1694(96)03128-9.

Thornton, P.E., Thornton, M.M., Mayer, B.W., Wilhelmi, N., Wei, Y., and Cook, R.B., 2012, Daymet-Daily surface weather on a $1 \mathrm{~km}$ grid for North America, 1980-2011: Oak Ridge Tennessee, Oak Ridge National Laboratory Distributed Active Archive Center. [Available at https:// daymet.ornl.gov/.]

Tillman, F.D., Leake, S.A., Flynn, M.E., Cordova, J.T., Schonauer, K.T., and Dickinson, J.E., 2008, Methods and indicators for assessment of regional ground-water conditions in the southwestern United States: U.S. Geological Survey Scientific Investigations Report 2008-5209, 22 p., https://doi.org/10.3133/sir20085209.

U.S. Census Bureau, 2001, Counties ranked by population size-July 1, 2001: U.S. Census Bureau. [Also available at https://www.census.gov/popest/data/counties/totals/2001/ CO-EST2001-06.html.]
U.S. Energy Information Administration, 2013, Annual energy outlook 2013 with projections to 2040: U.S. Department of Energy, DOE/EIA-0383(2013), 233 p. [Available at https:// www.eia.gov/forecasts/aeo/pdf/0383(2013).pdf.]

U.S. Geological Survey, 2018, Map of the principal aquifers of the United States: U.S. Geological Survey database, https:// water.usgs.gov/ogw/aquifer/map.html.

Vaccaro, J.J., Kahle, S.C., Ely, D.M., Burns, E.R., Snyder, D.T., Haynes, J.V., Olsen, T.D., Welch, W.B., and Morgan, D.S., 2015, Groundwater availability of the Columbia Plateau Regional Aquifer System, Washington, Oregon, and Idaho: U.S. Geological Survey Professional Paper 1817, 87 p., https://doi.org/10.3133/pp1817.

Vuke, S.M., Porter, K.W., Lonn, J.D., and Lopez, D.A., 2007, Geologic map of Montana: Montana Bureau of Mines and Geology Geologic Map 62 C, 2 sheets, scale 1:500,000.

Wanek, A., 2009, Recommended decision for City of Alexander water permit application No. 5990: Bismarck, North Dakota, Office of the State Engineer, North Dakota State Water Commission, $94 \mathrm{p}$.

Wesolowski, E.E.A., 1991, Estimated use of water in North Dakota in 1985 and trends during 1960-85: U.S. Geological Survey Water-Resources Investigations Report 89-4003, 1 sheet, https://doi.org/10.3133/wri894003.

Westenbroek, S.M., Kelson, V.A., Dripps, W.R., Hunt, R.J., and Bradbury, K.R., 2010, SWB-A modified Thornthwaite-Mather soil-water-balance code for estimating groundwater recharge: U.S. Geological Survey Techniques and Methods 6-A31, 60 p., https://doi.org/10.3133/tm6A31.

White, J.T., Fienen, M.N., and Doherty, J.E., 2016, A python framework for environmental model uncertainty analysis: Environmental Modelling \& Software, v. 85, p. 217-228.

Whitehead, R.L., 1996, Ground water atlas of the United States-Segment 8-Montana, North Dakota, South Dakota, Wyoming: U.S. Geological Survey Hydrologic Atlas 730-I, 24 p., https://doi.org/10.3133/ha730I.

Wilson, W.E., and Moore, J.E., 1989, Glossary of hydrology: Alexandria, Virginia, American Geological Institute, 248 p. 
Publishing support provided by the U.S. Geological Survey

Science Publishing Network, Tacoma Publishing Service Center

For more information concerning the research in this report, contact the Director, Wyoming-Montana Water Science Center

U.S. Geological Survey

3162 Bozeman Avenue

Helena, Montana, 59601

https://www.usgs.gov/centers/wy-mt-water 


\section{Groundwater Availability of the Williston Basin, United States and Canada}

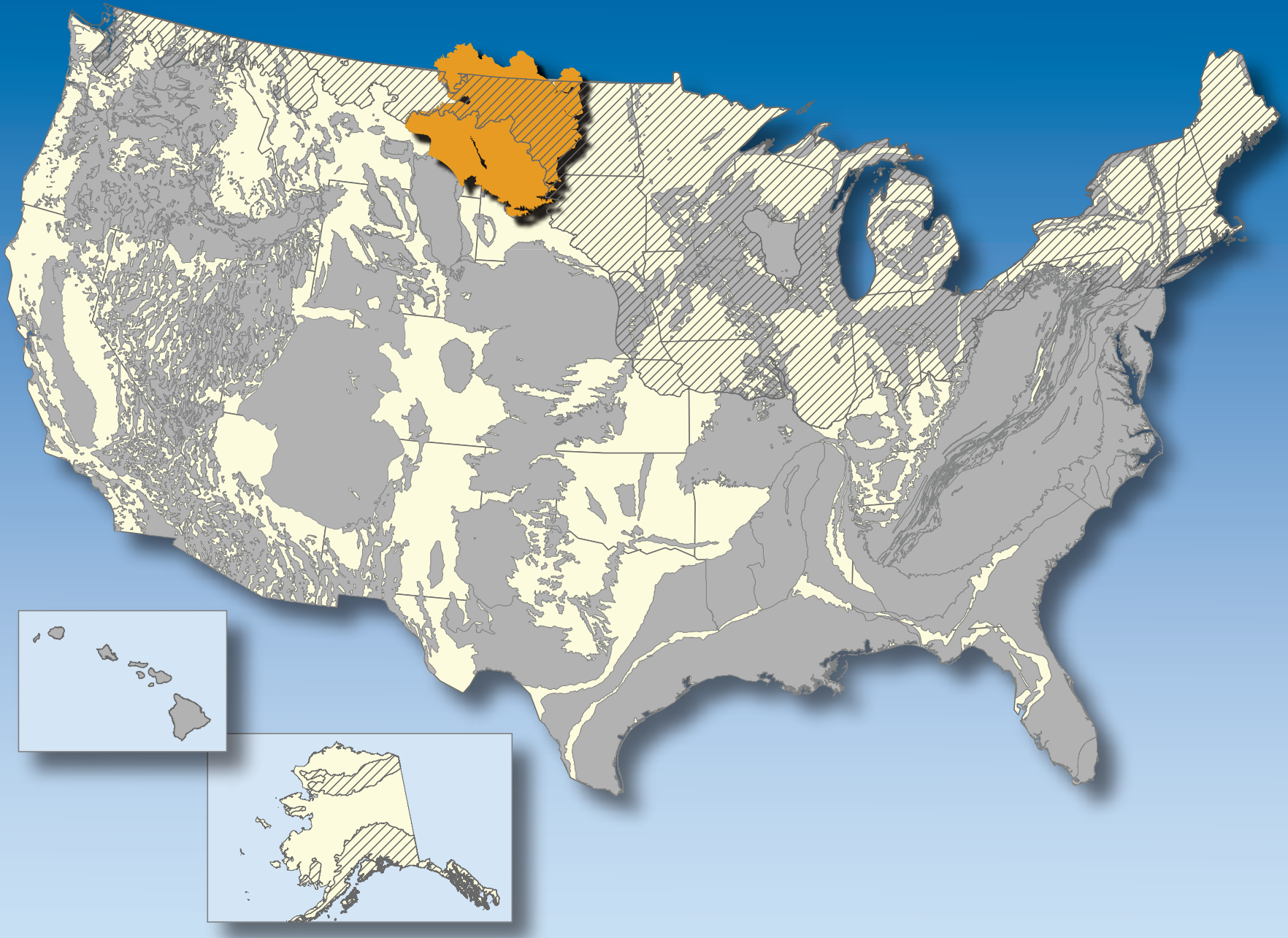

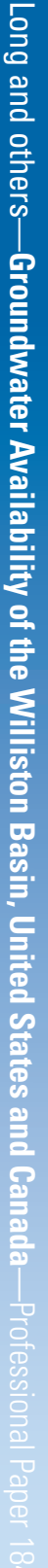

